\title{
رؤى ورسائل والقيم الجوهرية للمكتبات الجامعية
}

\section{دراسة مقارنة للبنية والمحتوى وطرح لمعايير الصياغة والتقييم}

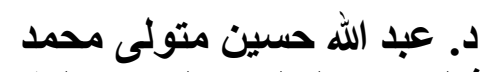

أستاذ المكتبات والمعلومات المساعد (المشارك)

قسم المكتبات والوثائق وتقنية المعلومات - جالمات المعة المعات القاهرة

(حالياً) استشاري حلول معرفية - قطاع إدارة الأصول المعرفية العادية

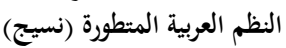

البريد الإلكتروني:Abdallah.Mohamed@naseej.com

مقدمة:

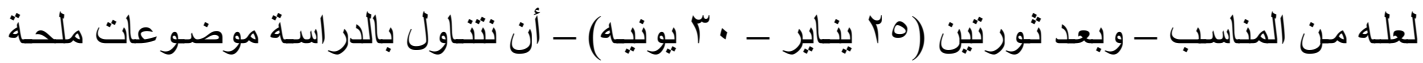

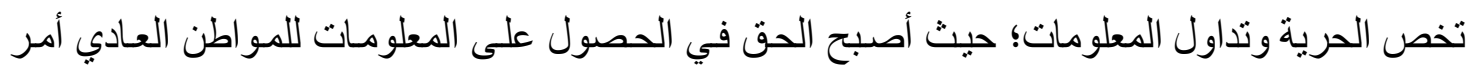
مهم وضـروري، كمـا أصـبحت هنـاك حاجـة ملحـة للحصول على المعلومـات وحريـة تـداولها لتحقيـق الثفافية و الصدق، وبناء الثقة بين الحاكم و المحكوم.

ومن هنا تبرز أهمية هذا البحث وأسباب اختياره في هذا التوقيت، لإبراز الحاجـة الماسـة إلى قانون لحريـة تداول المعلومـات، ومـا يترتب على ذلك من ممارسـات عمليـة، تتيح للمـواطنين بمختلف فئاتهم وتخصصصاتهم الحصول على المعلومـات، كذللك الضوابط التي تحكم هـذا الحـق، والتزامـات الدولـة و الموظفين تجاه هذا الحق، مع مر اعاة الأمن القومي للبلاد، و التوازن بين الإتاحة و الحجب ومبررات كل

ويتاول هذا البحث فكرة قانون حرية تداول المعلومات، وأصله في التشريع الدستوري و المقترح للقانون المعروض على رئيس الجمهوريـة، وأهداف هذا القانون وحق المو اطن في المعلومـات. وكيف يتم التعامل معها، هل يتم تقييدها أم إتاحتها، ومـا ينبغي إتاحته على الإطلاق ومـا مجالات الإتاحـة؟ استتادًا إلى دستور

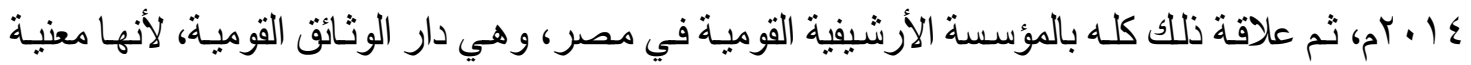

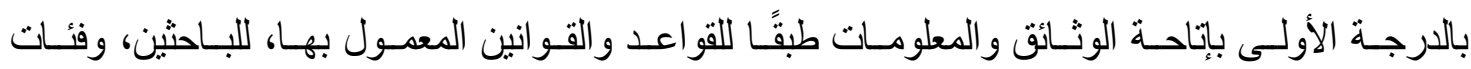

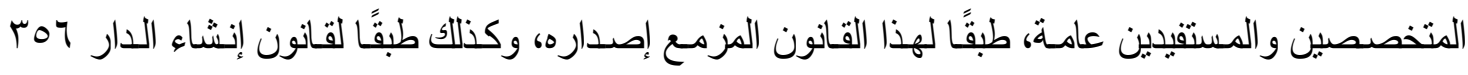

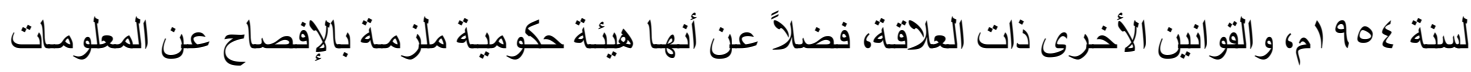
و البيانات الخاصة بها طبقًا للقانون مع مر اعاة تطبيق ذلك طبقًا للمعايير الدولية المعنية بذلك. وقد اعتمد البحث على القوانين التي لها علاقة بحرية تداول المعلومـات، فضلاً عن التطور الاستوري من 


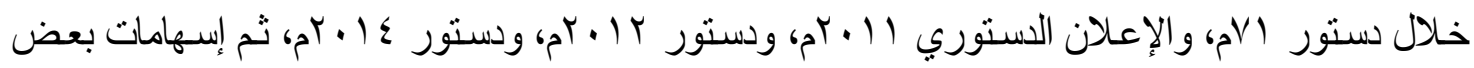
المفكرين في المجال وقد استفاد البحث كثيرًا من الدر اسـة القانونيـة المستفيضة في هذا الموضوع لبرنـامج الحق

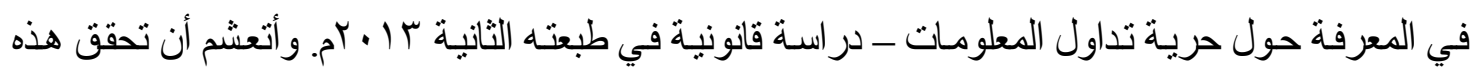
الدر اسة هدفها، وتضيف جديدًا في مجلال علم المعلومات و علاقته بالو ثائق. قانون حرية تداول المعلومات: ماهيته ــ الفكرة والنشأة:

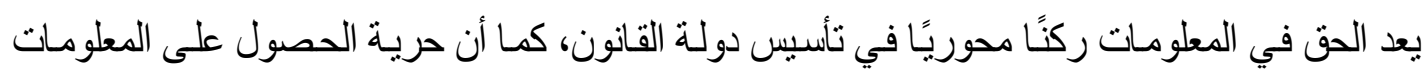
و إتاحتها واحدة من الحقوق الأساسية للإنسانية التي أقرتها الأمم المتحدة، وشددت عليه الجمعية العامـة للأمم المتحدة في دورتها الأولى عام 9 ام بالقرار رقم 109 1، حين أكدت أن "حريـة الوصدول إلى المعلومـات حق أساسي للإنسان، وحجر الزاويـة لجميع الحريـات التي تتادي بها الأمم المتحدة"؛ وهو الحق الذبي أسسته قو انين حرية "تداول المعلومـات" في أكثر من ثمانين دولة في العالم حتى الآن(')، كما أكد الإعلان العالمي

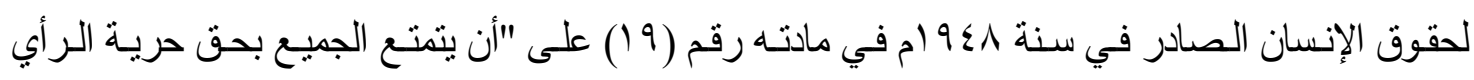
و التعبير..." كما أن حريـة الحصول على المعلومات، و إناحتها واحدة من الحقوق الأساسية للإنسان، كما أنسه

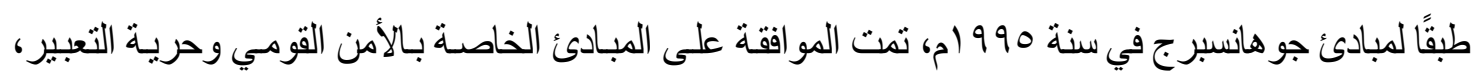
وحق الحصول على المعلومـات، وأكدت على ضرورة عدم تشجيع الحكومـات على استخدام ذريعة الأمن القومي لفرض قيود على ممارسة هذه الحريات(؟). وتأتي أهميـة قانون حريـة تداول المعلومـات من حيث كونـه يمهد الطريق لإنتهاج عدة مسار ات قانونية

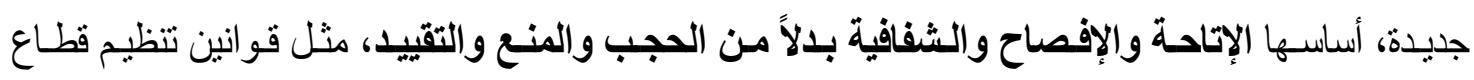
الاتصالات وخصوصية البيانات و الوثائق و المحفوظات، و غيرها، أي أن فلسفة هذا القانون أساسًا هي الإتاحة المبئيسة غير المقيدة، إلا مـا اسـتنى اسـتثناءًا محددًا في متن القانون نفسه، ومسئولية الأجهزة الحكوميـة والخاصة عن النشر الروتيني للبيانات بشكل دوري، وهو مـا يعرف بالإفصاح الاستباقي أو الإفصاح التلقائي (r)، مما يعزز حرية تداول المعلومات، كما أنه يقود عمل هذه الأجهزة وفقًا لمعيار جديد أساسـه تحكيم

الفائدة العامة في مقابل المصلحة الناجمة عن السرية('). أهداف القانون: لعل أهم أهداف هذا القانون ما يلي: ا ـ الاعتر اف بالحق في الحصول على المعلومات وفقًا للمعايير الدوليـة، ومبدأ ضرورة طرح المعلومات على نحو معلن في حالة عدم وجود سبب يقضي بسرية المعلومات، ويطغى على هذا الحق. r- وضع آليات و إجراءات لتعزيز الإفصاح عن المعلومات، بهدف الإسهام في تلبية احتباجات 
المجتمع من أجل حل المشاكل الاقتصادية و الاجتماعية واستيفاء منطلبات التخطيط و التنمية،

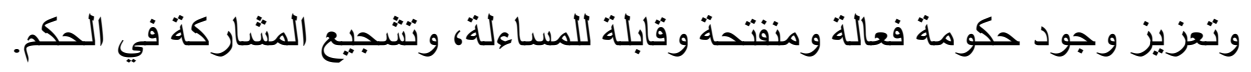

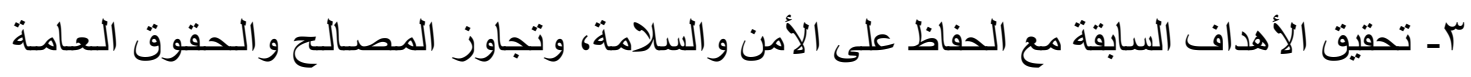

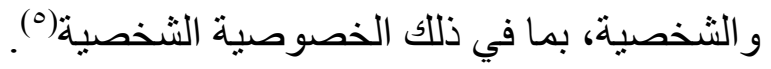

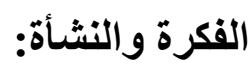

تتفاعل أغلب مؤسسات الدولة وهيئاتها البيروقراطية والإدارية، باعتبار أن الأصل في الأمور هو

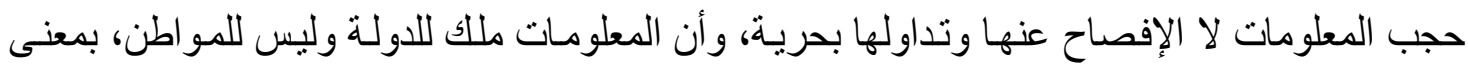

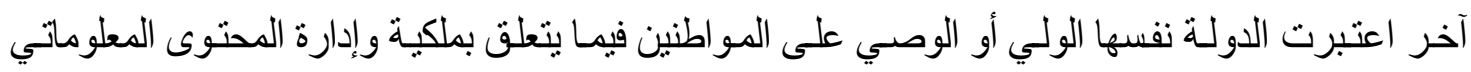

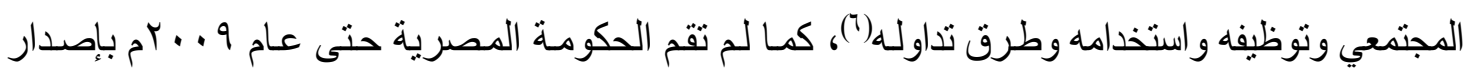

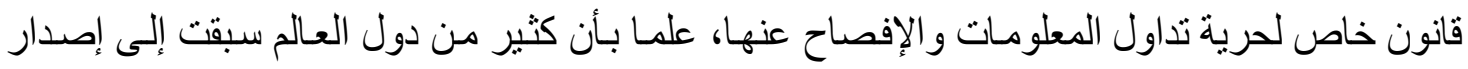

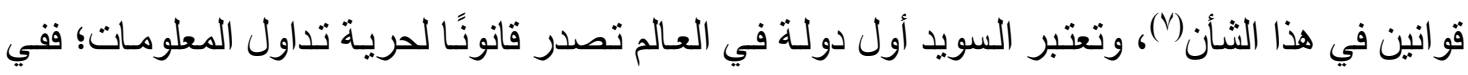

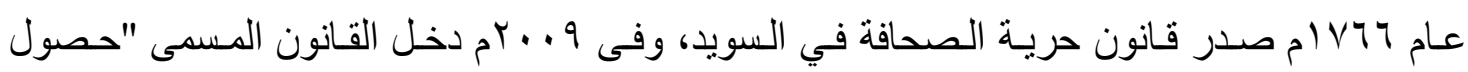

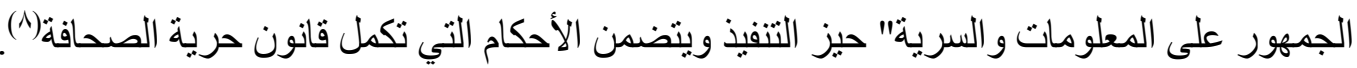

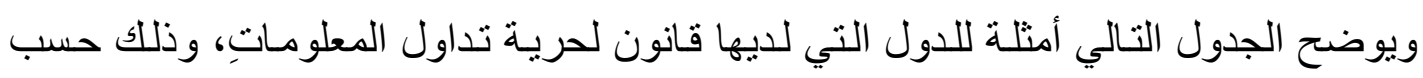

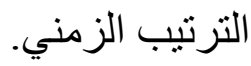

\section{أصل القانون في التشريع والاستور:

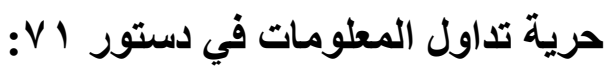

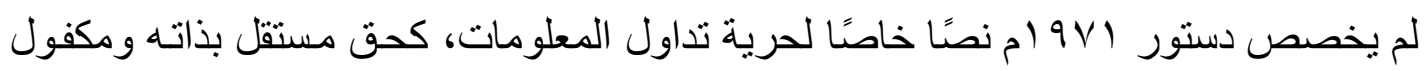

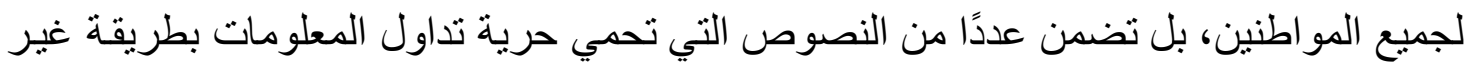

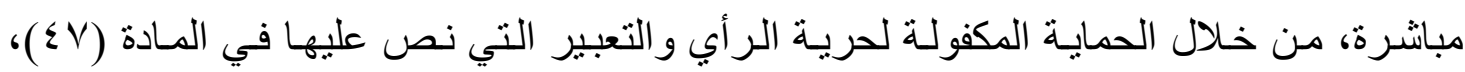

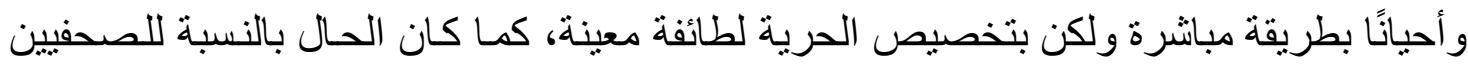
الذين كفل لهم الحق في الحصول على المعلومات بموجب المادة (· (r).

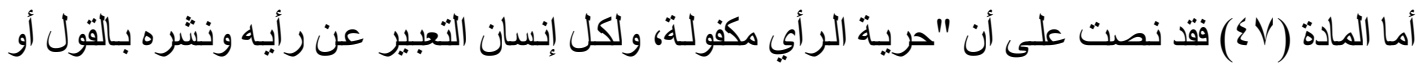

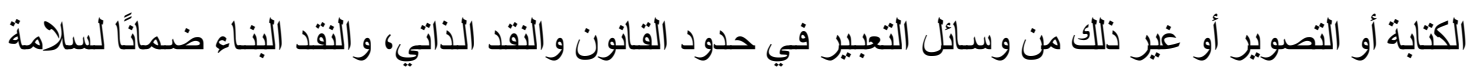

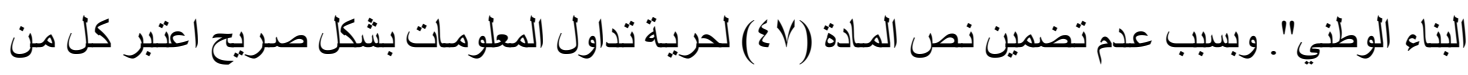
الفقه و القضاء في مصر أنها مكفولة وفقًا لروح النص، باعتبار أن حرية الر أي و التعبير هي أم الحريات جميعًا.

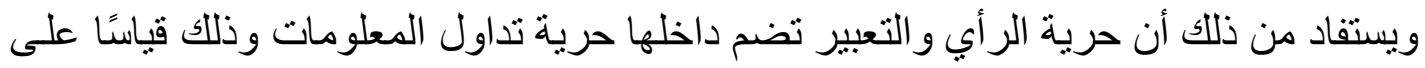

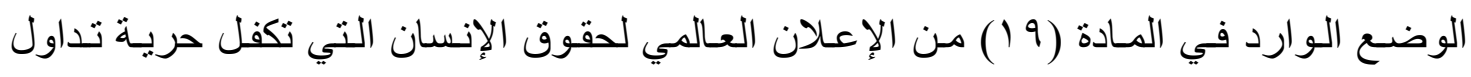


المعلومات من خلال الضمان الأشمل لحرية الر أي و التعبير (·').

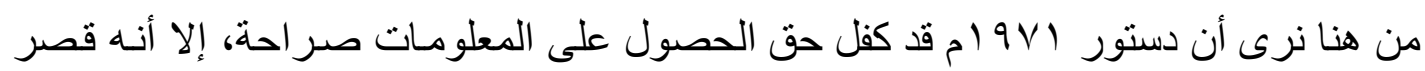
ممارسة الحق على الصحفيين وحدهم دون أن يمتد نطاق ذلك ليشمل الناس عامة، كمـا كفل حريـة تداول المعلومات بشكل غير مباشر في نص المـادة (^؟) التي نصت على أن "حريـة الصحافة و الطباعة والنشر ووسائل الإعلام مكفولة والرقابة على الصحف محظورة" وذلك انطلاقًا من أن

حريات الصحافة والإعلام و النشر لا يمكن تحقيقها إلا لضمان حرية تداول المعلومات وتدفقها.

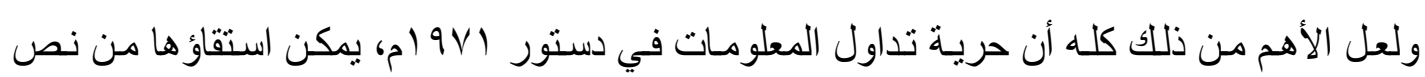
المادة (9 ) التي نصت على أن "تكفل الدولـة للمو اطنين حريـة البحث العلمي والإبداع الأدبي، والقني

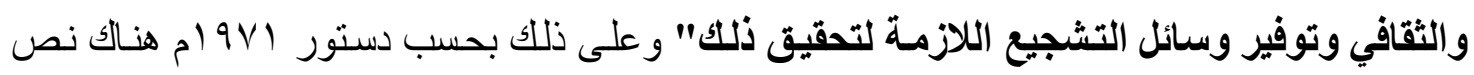
صريح في المادة (9) على حرية البحث؛ وهو الأمر المهم في مجال هذا البحث.

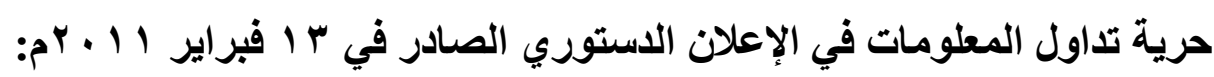

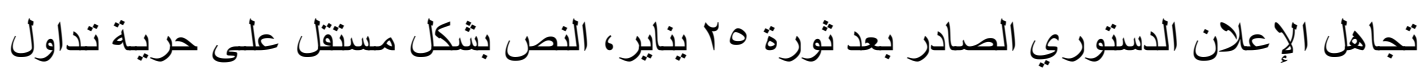

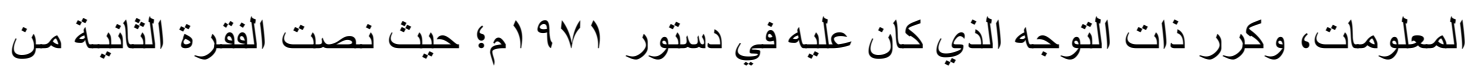

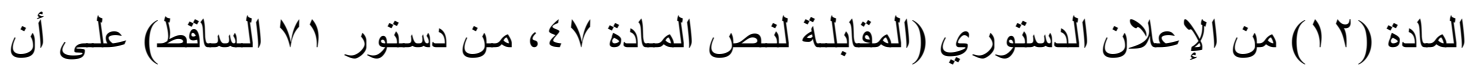

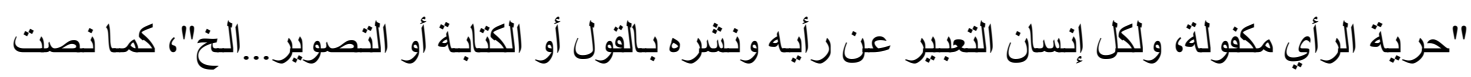

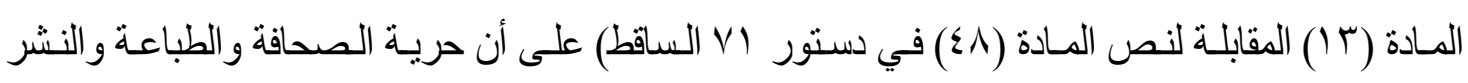
ووسائل الإعلام.. الخ"، ولم يتضمن الإعلان الستوري النص على حق الصحفيين في الحصول على المعلومات كما كان الحسال في دستور (9V) (م، وهو مـا يعد تر اجعًا في الاهتمـام بحريـة تداول المعلومات من ناحية إدر اجها في تشريع أساسي كالإعلان الدستوري. حرية تداول المعلومات في دستور r 1 ـ ب م (الفصل الثاني):

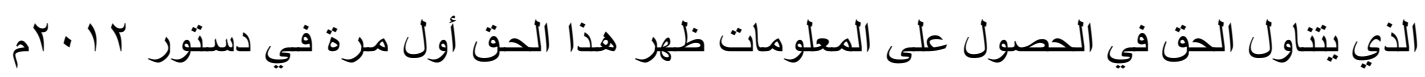

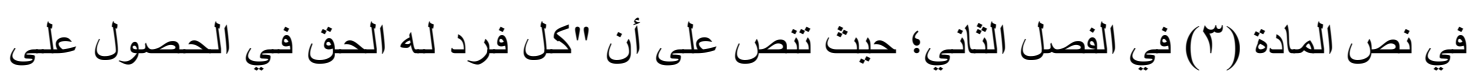
المعلومات التي تحتفظ بها الأجهزة الحكومية ويجب أن تلتزم تللك الأجهزة بالكثف عن المعلومات و السجلات الخاضعة لأحكام هذا القانون". وتتو الى المو اد بعد ذلك لكي تؤكد وتفصل هذا الحق، وكيفية تطبيقه بغض النظر عن وجود قو انبن

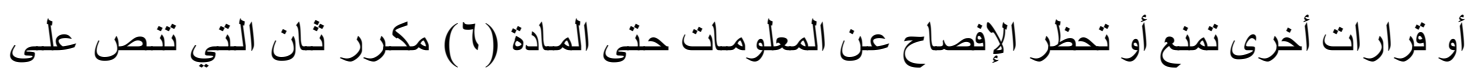

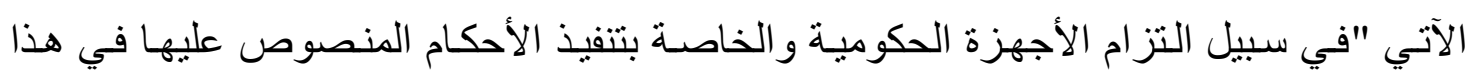


القانون يجب على الأجهزة الحكومية والخاصة حفظ المعلومات التي بحوزتها وفقا للقو اعد الواردة في قانون تتظيم دار الوثائق وفى لو ائح المحفوظات المختلفة (1)")"

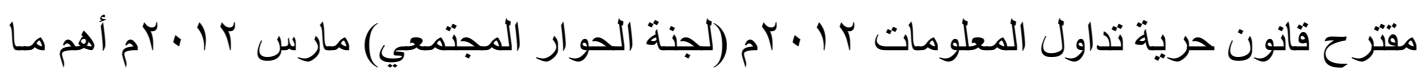
ورد في هذا القانون المواد التالية: الفصل الأول: الأحكام العامة: مادة ( (1): المعلومات التي في حوزة الجهات الخاضعة لتطبيق أحكام هذا القانون ملك للإنسانية، وتكلل الدولة للكافة الحق في الحصول عليها وفقًا للقو اعد والضو ابط و الشروط المنصوص عليها في هذا القانون، ويهذف هذا القانون إلى إتاحة الحصول على المعلومات احترامًا لحق الإنسان في المعرفة وتيسير حق المواطنين في الرقابة على الدولة.

مادة (r) ): في تطبيق أحكام هذا القانون يقصد بالكلمات الآتية المعنى قرين كل منها: المعلومـات: هي البيانـات والإحصاءات و الوثنائق الموجودة أو المحفوظة في في أي مـن السجلات و الوثائق المكتوبة أو المحفوظة إلكترونيًا أو الرسومات أو الخرائط أو الجداول أو الصور أو الميكروفيلم أو التسجيلات

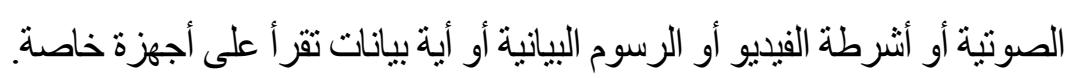
المجلس: المجلس القومي للمعلومات. المختصون بتطبيق هذا القانون: موظفو المعلومات ومعاونيهم. مادة (ץ): تخضع لأحكام هذا القانون: 1 - جميع السلطات العامة وأجهزة الدولـة الإداريـة و الأشخاص الاعتباريـة العامـة عدا مـا يستثنى منها بنص صريح. r ـ الأشخاص الاعتبارية الخاصـة المملوكة للدولة أو التي تساهم فيها أو تقوم بالإشر اف أو الرقابة عليها. r ـ الجهات التي تخضع لرقابة الجهاز المركزي للمحاسبات.

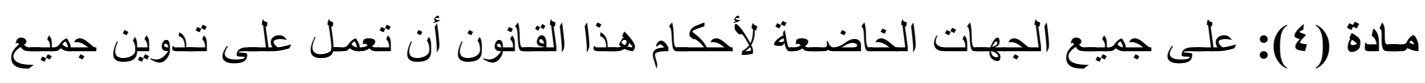
أعمالها، كما يجب عليها الاحتفاظ بمستنداتها وحفظها وصيانتها، وأن تعمل على فهرستها بالشكل وبالطريقة التي تيسر الوصول إلى المعلومات في فترةزمنية معقولة. مادة (•): لا يلزم أي فرد لـه الحق في الحصول على المعلومات بإبداء أي مبررات لتقديم

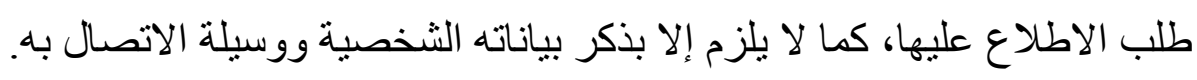

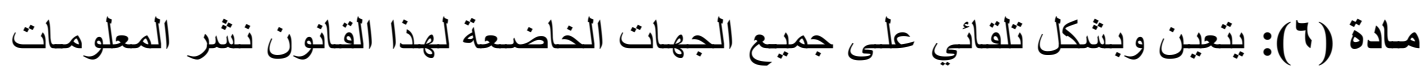
الأساسية على اختصاصاتها، على أن تتضمن على الأخص عنو ان الجهة، وأرقام هو اتفها وبريدها 
العـادي و الإلكتروني، و الإطـار القانوني الحـاكم لنشاطها و الاختصاصـات و المهام المنوطـة بها، و الهيكل الإداري و التنظيمي لها... ودليل يشمل كبار المسئولين و الموظفين بالجهة وسلطاتهم وواجباتهم

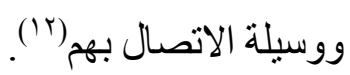

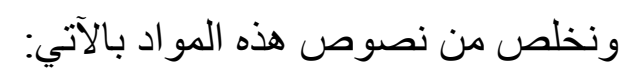

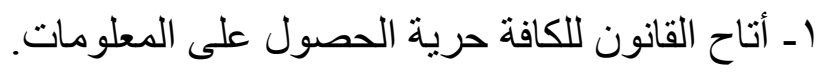

r- قدم تعريفات للمصطلحات المستخدمة في نص القانون.

r- نص على ضـرورة أن تدون الجهات الخاصـة للقانون معلوماتها، وتحتفظ بها وتصونها

$$
\text { و تقوم بإعدادها إعدادًا فنيًا يسمح باستر جاعها في سهولة ونيس ويسر. }
$$

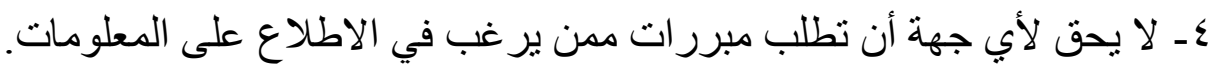

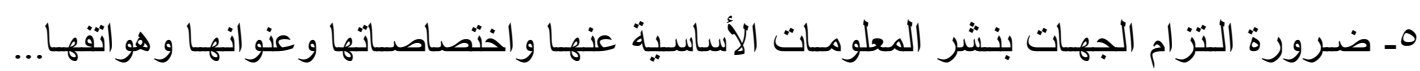

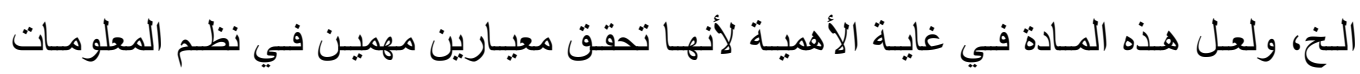

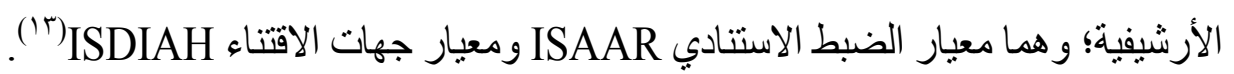

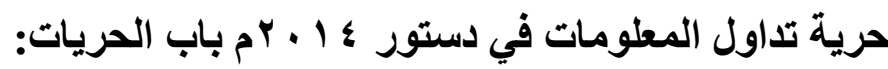

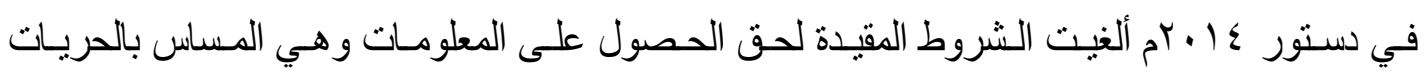
الخاصـة، حقوق الآخرين، التعـارض مـع الأمن القومي، مسن نص المـادة مج التي أحالت كل هذه الأمور للقانون، كما أضيف نص يلزم مؤسسات الدولة بحفظو تأمين الوثائق.

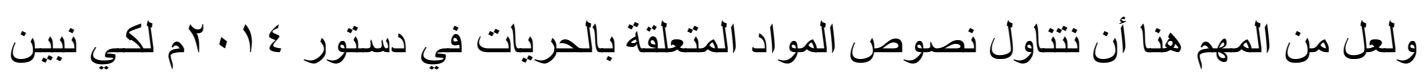
المكاسب التي حصل عليها المو اطنون طبقًا للاستور وهي: مادة بr r تكفل الدولة حرية البحث العلمي وتشجيع مؤسساته باعتباره وسيلة لتحقيق السيادة الوطنية وبناء اقتصاد المعرفة، ويرعى الباحثين و المختر عين، وتخصص لله نسبة من الإنفاق الحكومي لا تقل عن ا\% من ولناء الناتج القومي. مـادة اب: أمن الفضاء المعلوماتي جزء أساسي من منظومـة الاقتصـاد و الأمن القومس، وتلزم

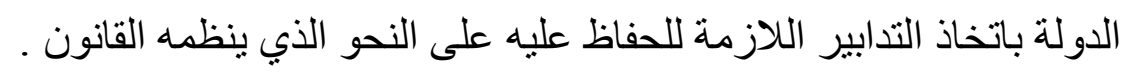
مادة ^^ ؟ : الثقافة حق لكل مو اطن. مادة ه 7 مادة حرية الفكر والر أي مكفولة، ولكل إنسان حق التعبير عن رأيه بـالقول أو الكتابـة أو التصوير أو غير ذلك، من وسائل التعبير و النشر.

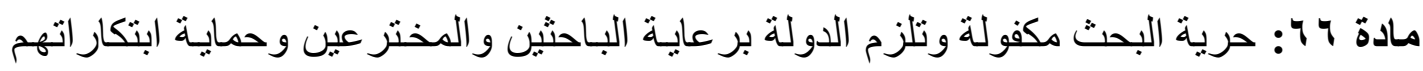
و العمل على تطبيقها. 
مادة 1 7: المعلومات و البيانات والإحصاءات و الوثائق الرسمية ملك للشعب و الإفصاح عنها من مصادر ها المختلفة حق تكفله الدولة لكل مواطن، وتلتزم الدولة بتوفير ها و إتاحتها للمو اطنين بشفافية،

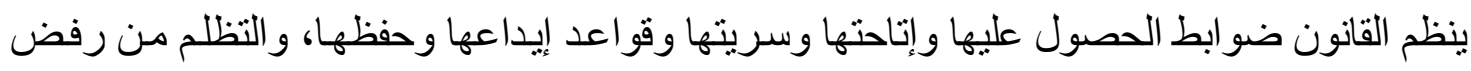
إعطائها، كما يحدد عقوبة حجب المعلومات أو إعطاء معلومات مغلوطة عمدًا. وتلتزم مؤسسات الدولة بايداع الوثائق الرسمية بعد الانتهاء من فنرة العدل بها بـدار الوثائق القومية،

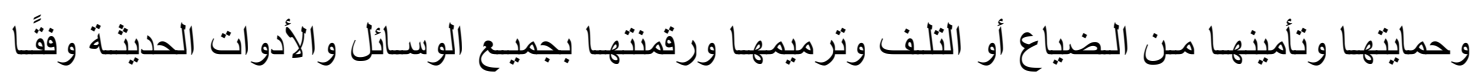
للقانو، وبتحليل نصوص مو اد الدستور السابقة يتضح لنا ما يلي:

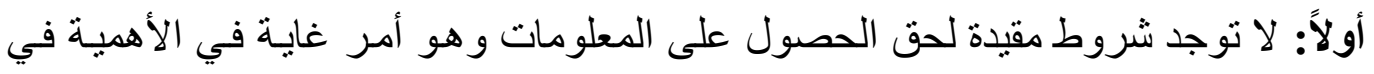

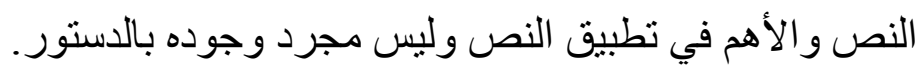

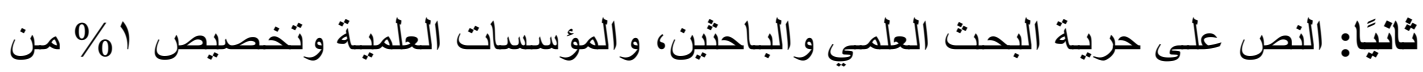
الدخل القومي لأول مرة له وتز اد تدريجيًا.

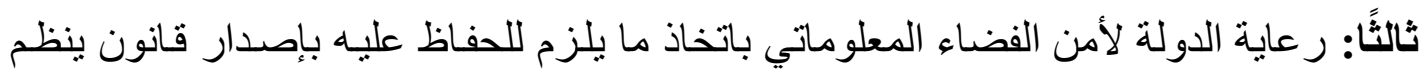
العمل فيه.

رابعًا: الثقافة ليست حكرًا على فرد معين ولكنها مكفولة ومتاحة لجميع المو اطنين.

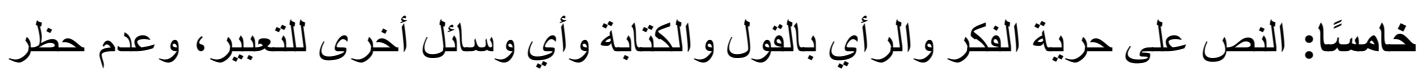
أي فكر. سادسًا: أهم المواد على الإطلاق والتي لها علاقة بمجال هذا البحث وهي المـادة (1/)؛ و التي تنقسم إلى شقين الأول هو ملكية الثعب للمعلومات بكل أنواعها، وأن الدولة تكفل حق الإفصاح عنها من هن

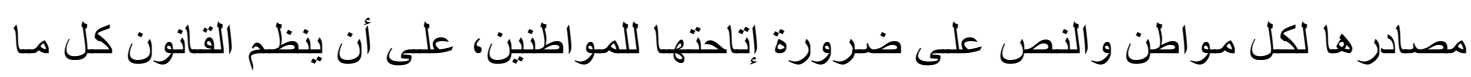

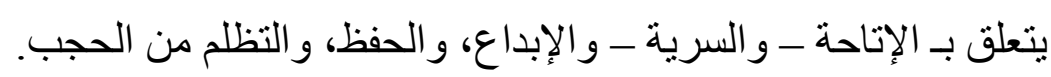

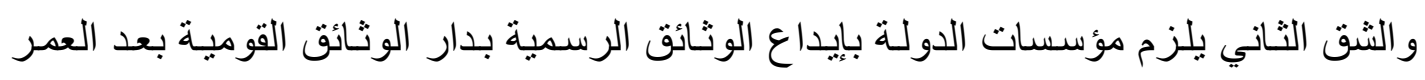

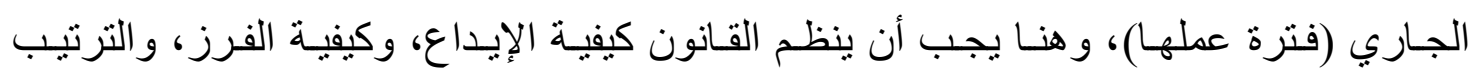

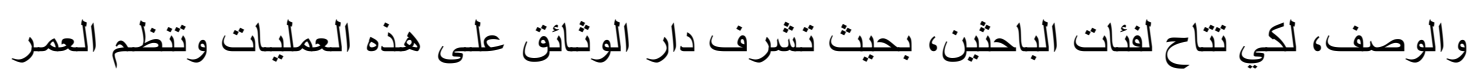
الوسيط للوثائق و وكانه وضرورة تبعيته لها.

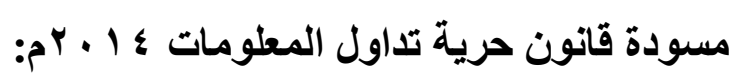

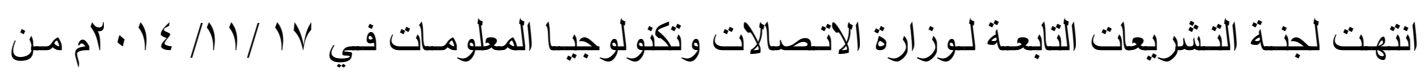
صياغة مسودة قانون حريـة تداول المعلومات، في انتظار موافقة رئيس الجمهوريهة، ويتضمن البـاب الأول:

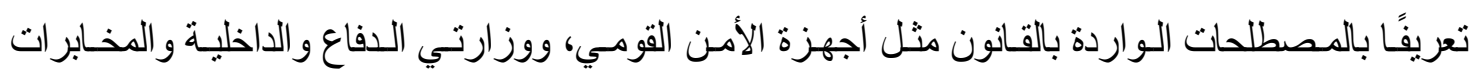


العامـة. وأن الإفصـاح هو إجر اء من شأنه إتاحـة البيانـات أو المعلومـات بأي وسيلة، أمـا الأمن القومي وفقًا لتعريف القانون - فهو كل ما يمس استقال البلاد أو وحتنها أو سلامة أر اضيها.

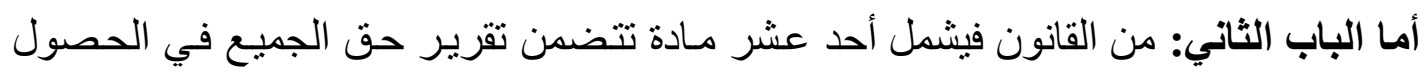

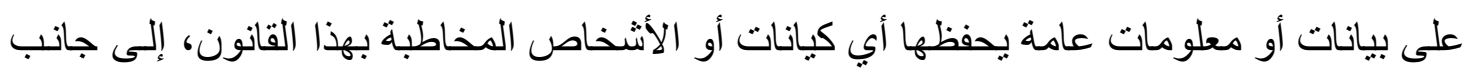

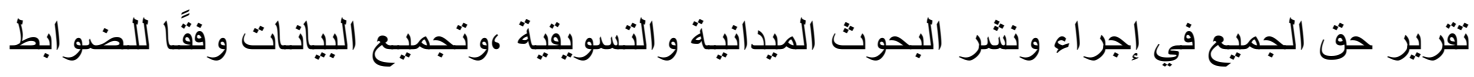

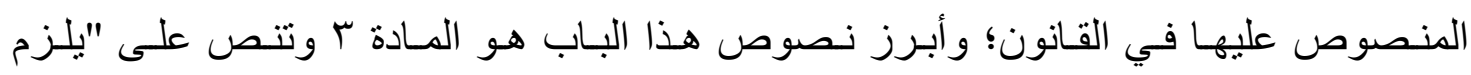

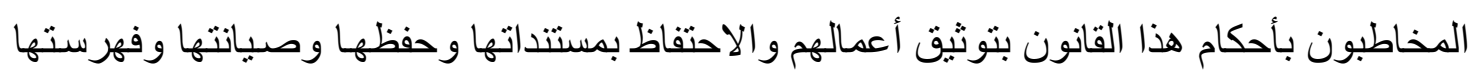

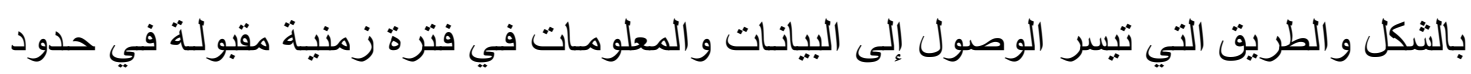
الموارد المتاحة".

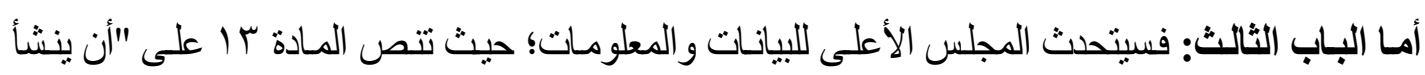

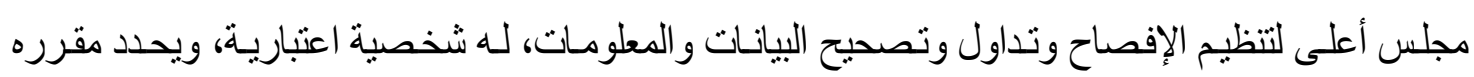

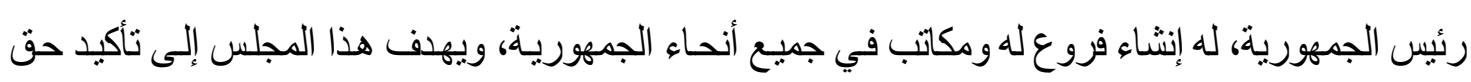
المواطن في الوصول إلى البيانات و المعلومات".

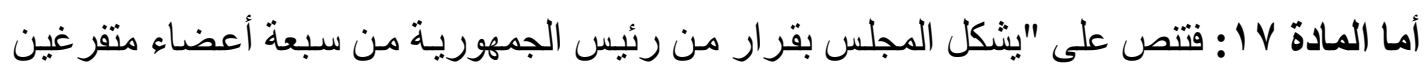

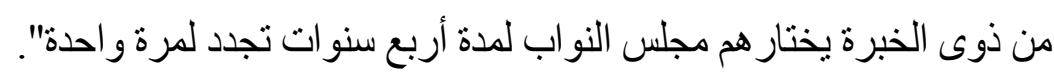

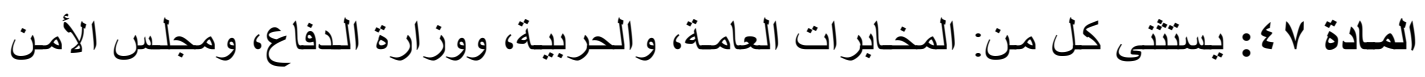

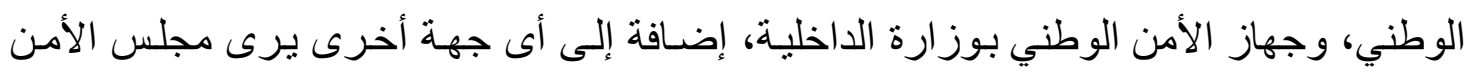

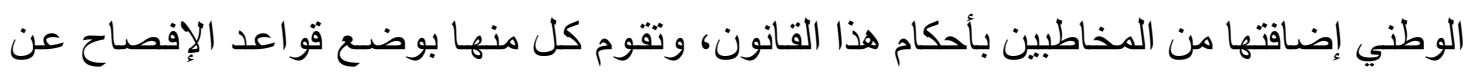

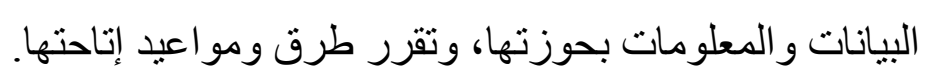

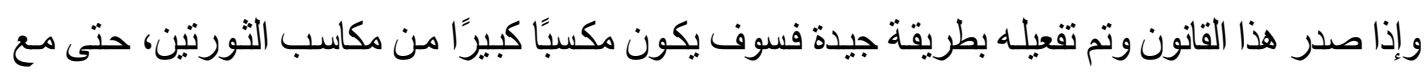

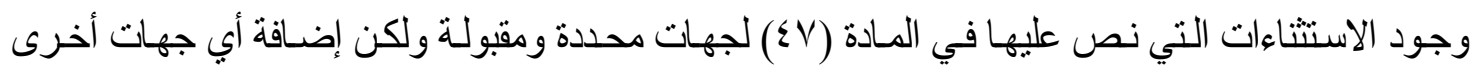

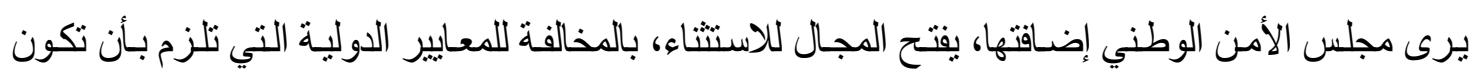

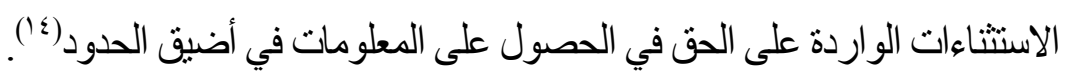

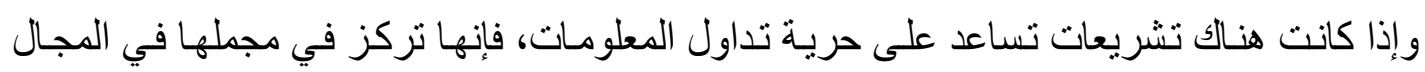

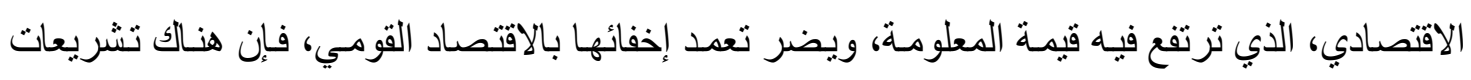

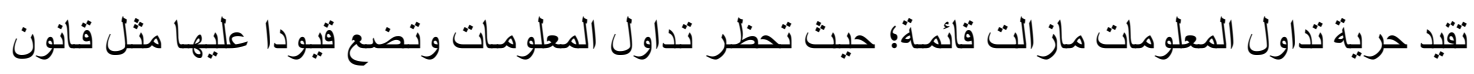

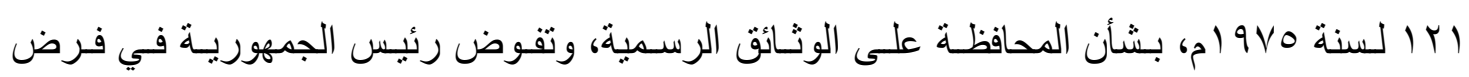

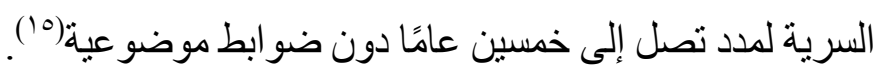


ولعل أهم التحديات التي تواجه إتاحة المعلومات في مصر هي:

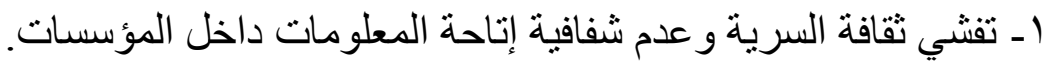
r - عدم وجود سياسة أو استر اتيجية قومية للإحصاء و المعلومات. rـ ضعف كتابة التنسيق بين الجهات المنتجة للمعلومات. عـ غياب آليات مر اقبة جودة البيانات بما يؤثر على الصصداقية و الثقة في البيانات.

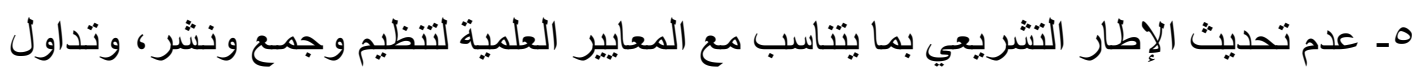
المعلومات بسهولة، وفى التوقيت المناسب. 7ـ قصور بر امج إعداد القدرات البشرية المؤهلة، وغياب المهارات المطلوبة. V- الطبيعة المزدوجة للجهات العاملة في منظومة الإحصاء و المعلومات في مصر (17') . نخلص من ذللك كله إلى أنه على الرغم من أهمية وجود قانون ينظم عملية تداول المعلومات المات

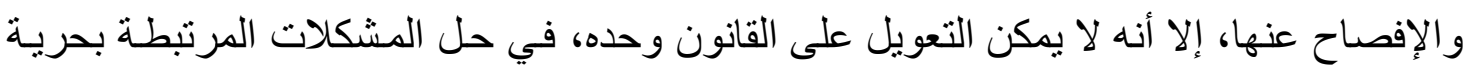

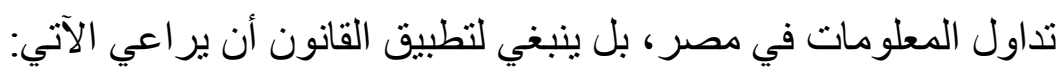

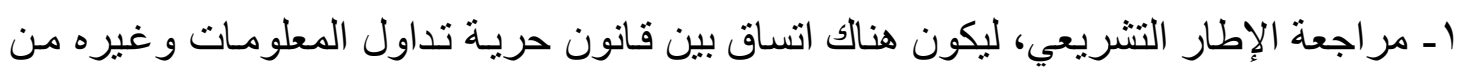

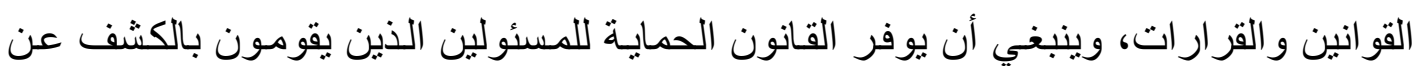
المعلومات لتغيير ثقافة عدم الثفافية في مؤسسات الدولة.

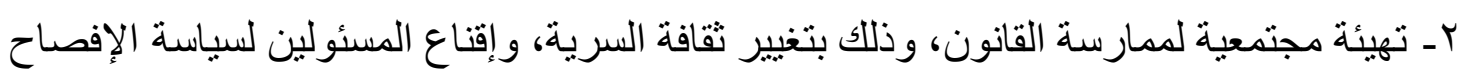
لا الحجب، إلى جانب تثقيف الجمهور ونشر الوعي بالقانون وحقوق الأفراد عن طريق الإعلام

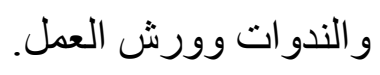

rــ لابد للمؤسسة المقترحة لتنفيذ قانون حريـة تداول المعلومات في مصر (مجلس أعلى لتنظيم

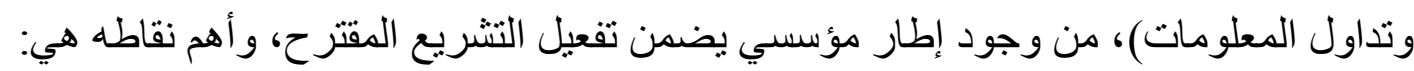

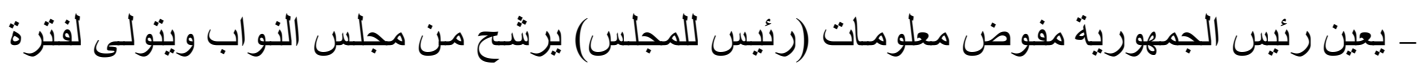
محددة، ويقام تقريرًا سنويًا عن عمله لمجلس النواب.

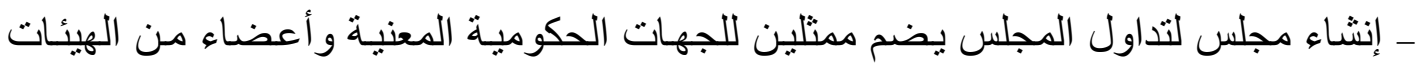
غبر الحكومية والخبراء المتخصصين. ـ تفعيل مبدأ إتاحة المعلومات بالالتز ام بتعيين مسئول للمعلومات في كل جهاز حكومي، مع المعان

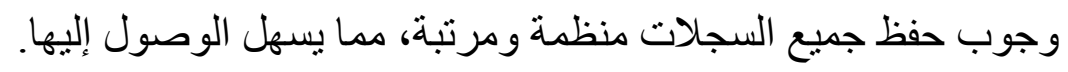

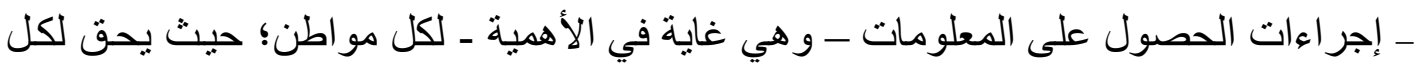


فرد أن يقدم طلبًا شفويًا أو مكتوبًا، إلى الجهة الحكومية أو الخاصة، كما يتعين على مسئول

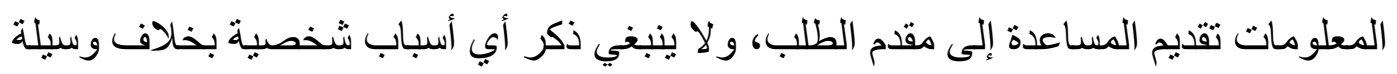

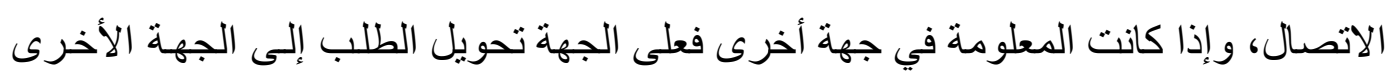
و إخطار مقدم الطلب، وذللك في فترة زمنية يحددها القانون . تكلفة الحصول على المعلومات(1')

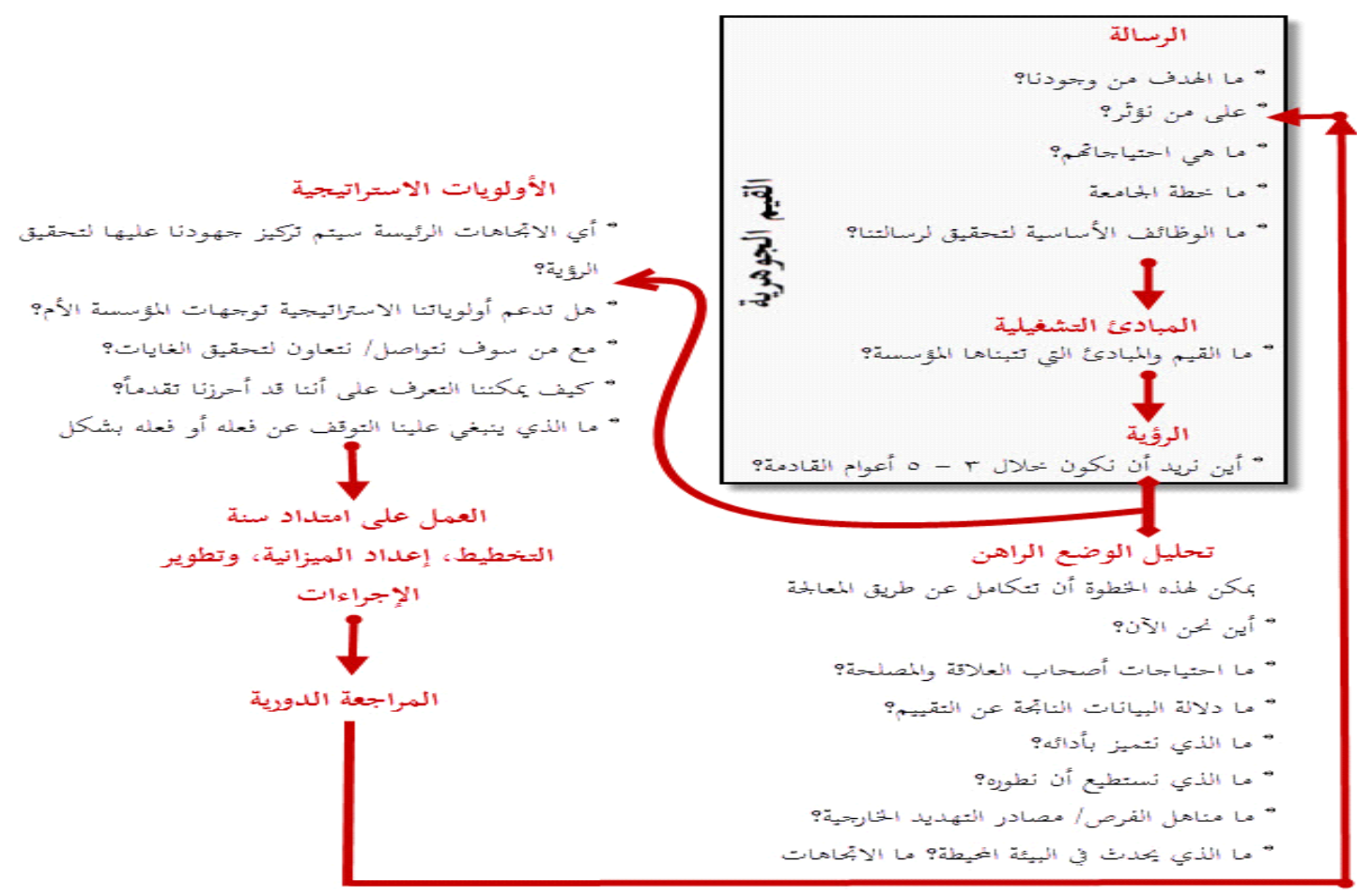

شكل (1) أنموذج للتظطيط الاستراتيجي بجامعة ويسكونسن- ماديسون يوضح العلاقة التي تربط كل من الروية والرسالة والقيم الجوهرية (منقول بتصرف) فإذا ما تم ذلك كله وتحقق إطار تطبيق قانون حرية تداول المعلومات في مصر ، سوف تكون ترن

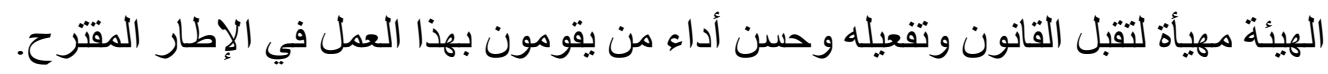

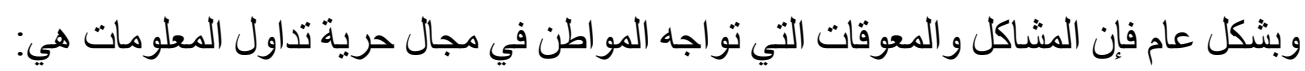
ا - في مجال توافر المعلومات والإحصاءات نجات المعات

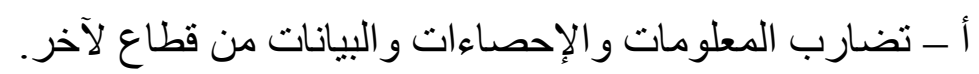

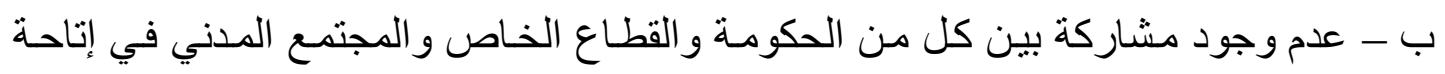
المعلومات وتداولها. 
ج- عدم وضوح فكرة الإتاحة المعلوماتية و البيانات. دـ عدم تو افر الوسائل المتنوعة التي تتناسب مع احتياجات المو اطنين. هـ اعتماد البعض على المصادر الأجنبية. و - نقص جودة الإحصاءات و المعلومات و الازدو اجية في نشر ها(^^ا'. r - في مجال القيود القانونية على حرية تداول المعلومات نجد:

كثرة القيود القانونيـة الخاصـة بنشر البيانـات و المعلومـات من خـلال الصحف الصـادرة مثل

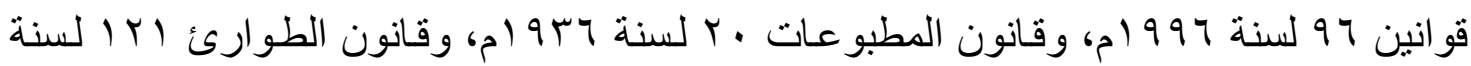

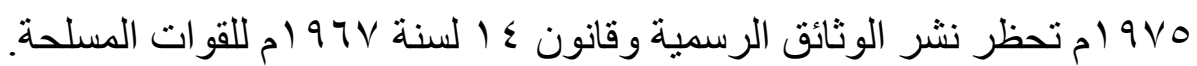
قلة التشريعات التي تحكم شبكة الإنترنت(9) (19) علاقة دار الوثائق القومية بالاستور وقانون حرية تداول المعلومات بعد تتاول فكرة حرية تداول المعلومات وضرورة وجود قانون بنظم المعلومات وحق المو اطن في الحصول عليها، بصفة عامة، فلا شك أن هنالك علاقة قويـة بين دار الوثائق القومية، وقانون حرية تداول المعلومات المزمع صدوره، و هذه العلاقة تتمثل في جانبين هما:

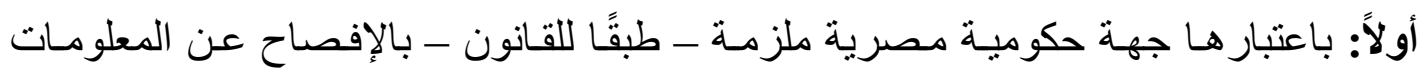
و البيانـات الخاصـة بها (هيكلها التنظيمي- نظـام العمل بها- وظائفها ومهامها وأهدافها... التخ)، بصفة دورية ودون طلبها؛ و هو الإفصاح الاستباقي، و عند طلبهاو هو الإفصاح التفاعلي(·r). ثانيًا: باعنبار ها جهة خدمية ثقافية، تخدم فئات مختلفة و أنماط متنو عة من الباحثين و المستفيدين عامة، وما يتعلق بذلك من إتاحة وحجب للوثائق طبقًا للقو انين واللوائح المعمول بها في الدولة، و الخاصة بدار الوثائق ودار المحفوظات و غير ها، وما يصر حسه به قانون حريسة تداول المعلومـات، وبالتالي فسوف يتم تناول هذه العلاقة بالدر اسة في هذا البحث على النحو التالي:

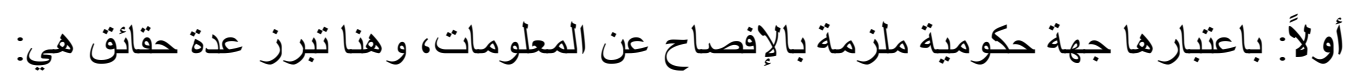
ا ـ لا يوجد لدار الوثائق أي نوع من التوصيف للوظائف، و لا تطبق أب أي معايير دولية أو محلية لعمل هذا التوصيف، بل إن الهيكل التنظيمي لها هو نفسه منذ سنة 907 ام تاريخ بده العمل

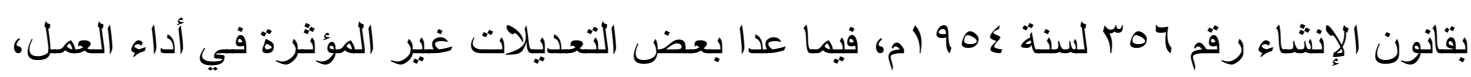
خاصة وأن الهيكل التنظيمي للحكومة، يختلف - حاليًا اختلافًا كبيرًا عن الهيكل في زمن صدوف عدور القانون(r)"، و هناك - حاليًا إعداد لهيكل تتظيمي جديد يقوم بـه جهاز التنظيم والإدارة ولا يعلم 


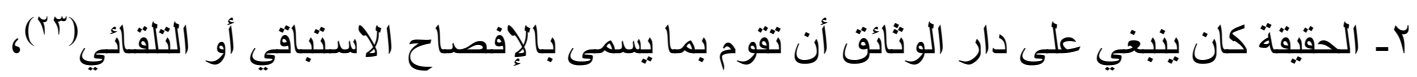

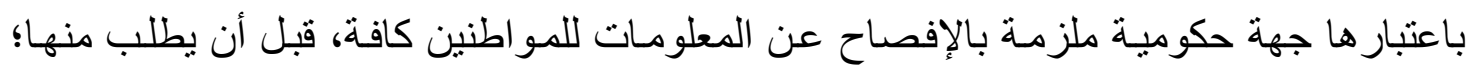
حيث يعرف تقديم الأفر اد لطلب الحصول على المعلومات بالإفصاح التفاعلي الذي لا يتم أيضًا بشكل منضبط. بـ كـان مـن الضروري أن تطبـق دار الوثنائق المعيـار الدولي لوصـف الوظـائف (ISDF) بالنسبة لكل الوظائف التي تؤديها، و المهام المنوطة بها، حتى يمكن قياس الأداء، ولكن نظرًا

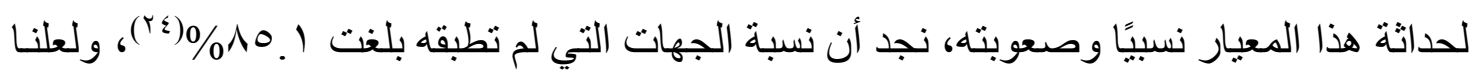
نلتمس العذر لدار الوثائق في عدم تطبيقه، وإن كنا لا نلتمس لها العذر في عدم تطبيق معيسار التقنين الدولي للوصف الأرشيفي (ISAD) بأي حال.

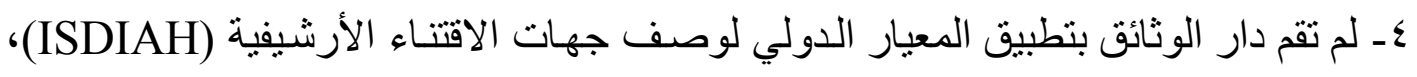

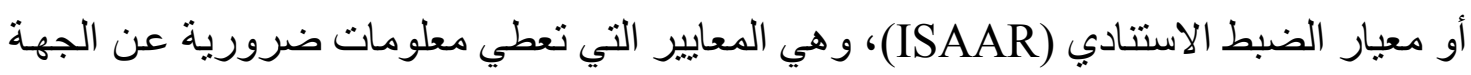

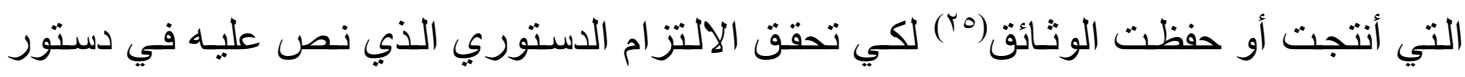

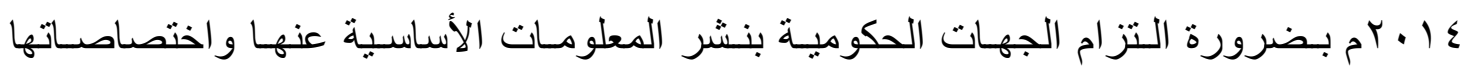
و عنو انها و هو اتفها وبريدها و الإطسار القانوني الحساكم لنشاطها، و المهام المنوطـة بهـا، و الهيكل الإداري و التظظيمي لها؛ حيث بنص الدستور على ذللك و على أن يتم بشكل تلقائي ودوري.

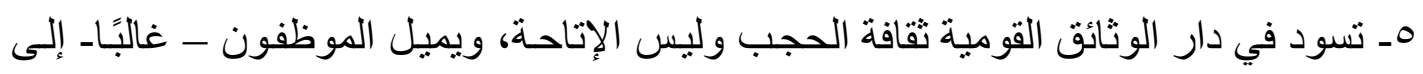
التكتم في الإدلاء بالمعلومات أكثر من الإفصاح عنها. وقد تكون هذه الثقافة هي احدى التحديات

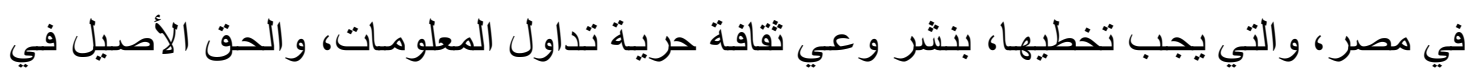

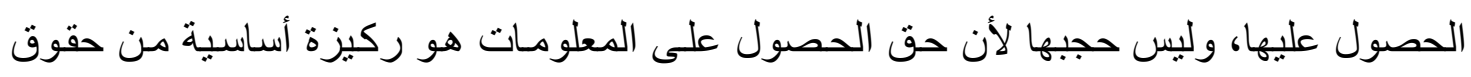

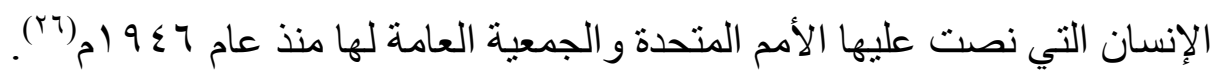
يتعامل مع دار الوثائق للحصول على المعلومات فئتان رئيسيتان هما: ا ـ المستفيدون من طالبي الوثائق و المعلومـات، ونسخ منها، وهي خدمات عامـة تقدم لجمهور المو اطنين. r ـ الباحثون من مختلف التخصصات من داخل وخار ج مصر.

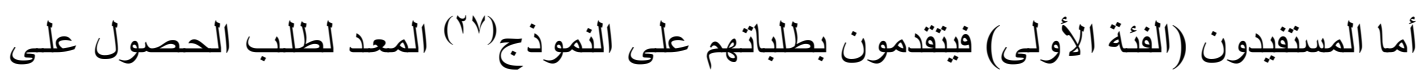

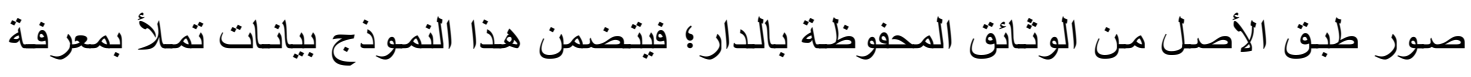

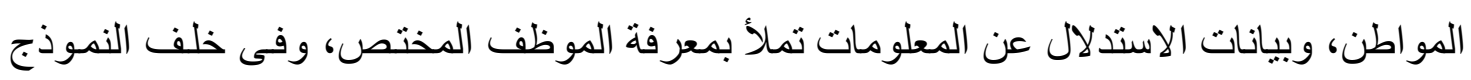
بيانات تتعلق بالأوراق المطلوبة وبلية وهى: 
ـ ما يفيد إثبات الشخصية للاطلاع عليه وصورته وهو أمر طبيعي.

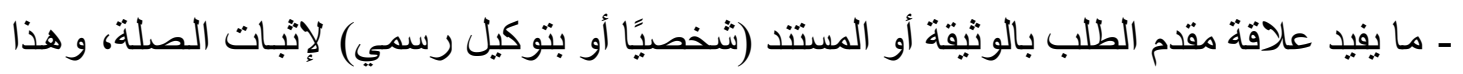

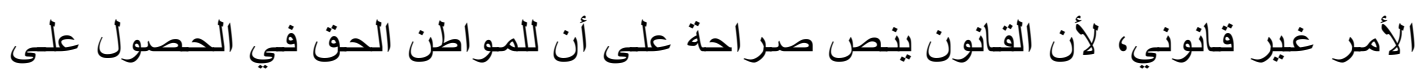
المعلومة دون إبداء أسباب أو مبررات لان أو شروط. ـ المدة المحددة لإنجاز الطلب شهر، ويعتبر لاغٍ بعد مرور ثناثتة شهور من تاريخ التقديم، وهذا

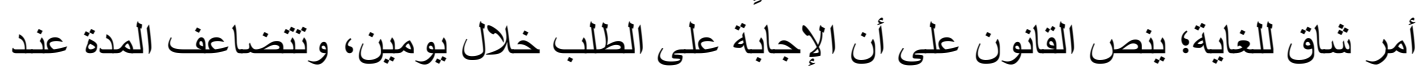

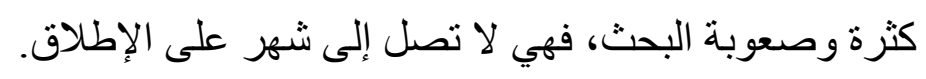
ـ في نهاية البيانات بالنموذج توجد ملاحظات: الأولى تقديم طلب جديد في حالة تغيير البيانات، و الثانية في حالة عدم الحصول على الخدمة في التوقيت المحدد أو طلب مبالغ إضافية تحت أي لي

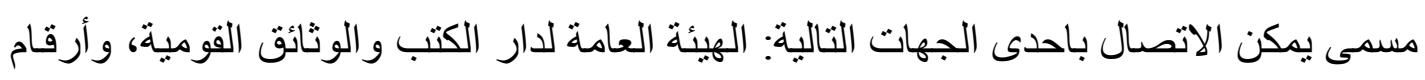

تليفوناتها، و هيئة الرقابة الإدارية ورقم تليفونها. و هذا أمر جيد ومهم لأن القانون يعطي الحق للمواطن للتظلم ومعرفة سبب الرفض أوفي أو عدم

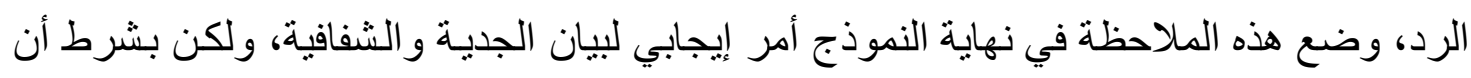
تكون الإجر اءات فاعلة وناجزة وصحيحة، و لا تكون هذه البيانات مجرد شكل يوضع في النموذج لاستيفاء الشكل القانوني.

\section{ثانيًا: علاقتها بالقانون باعتبار ها جهة خدمية ثقافية:}

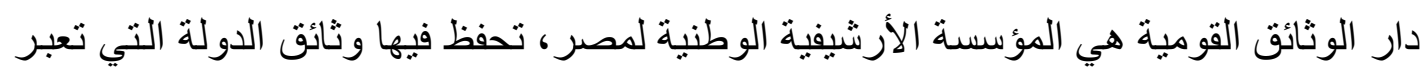

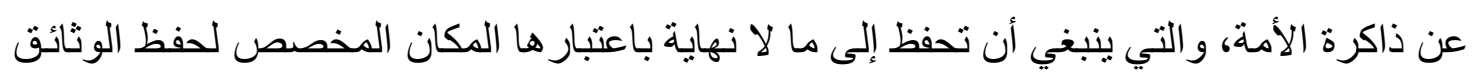

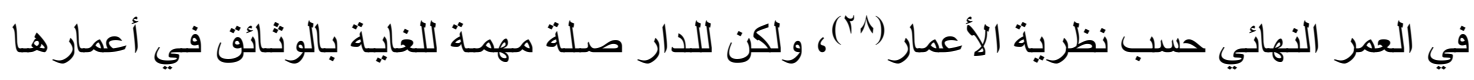
الجارية والوسيطة(ج9)، بمعنى أنه لا يجوز التصرف في وثائق الدولـة بأي نوع أو طريقة للفرز

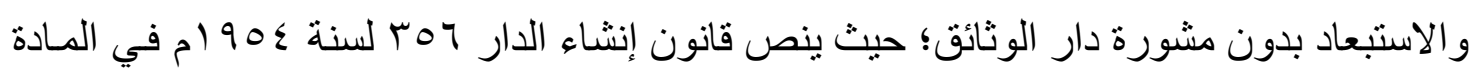
ب بند ج على أن الدار هي الجهة الوحيدة التي لها الحق في إبداء الرأي في إعدام الأوراق الخاصة

ل تلكل وزارة.

وتمنع المادة (1) (1) أي جهة من التخلص من أور اقها إلا بعد تقديم تقرير عنها إلى دار الوثائق القومية لتبدي رأيها في الأوراق المطلوب التخلص منها، و لا يجوز التصرف في الأوراق إلا بعد أخذ رأي الدار. ولمتابعة هذا الأمر وتتفيذه، ومن هذا المنطلق قام الدكتور رئيس دار الوثائق

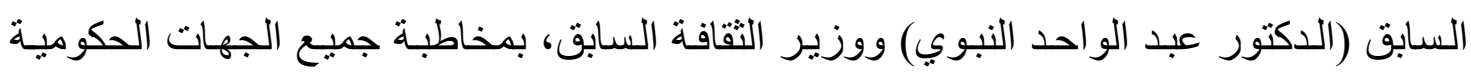
بخطاب دوري شرح فيه هذا الأمر، وذكر ما نصه "على الرغم من وجود عدة قوانين وقرارات 


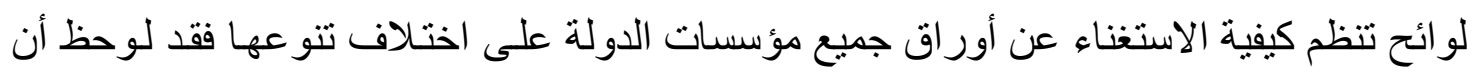

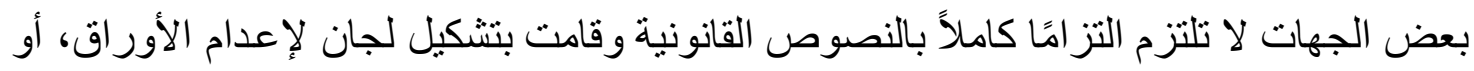

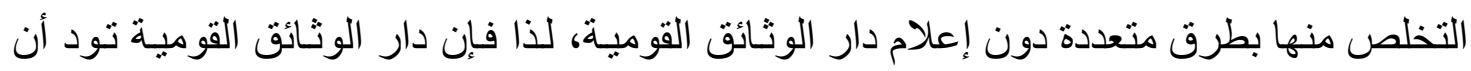

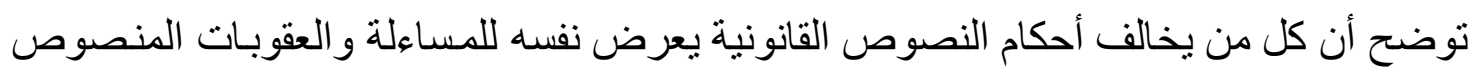

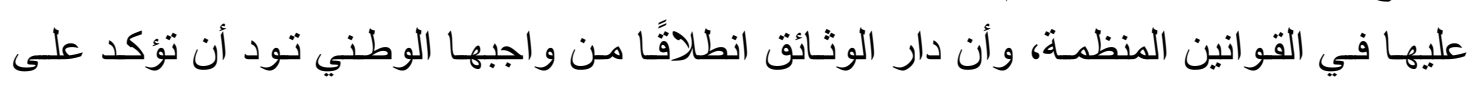

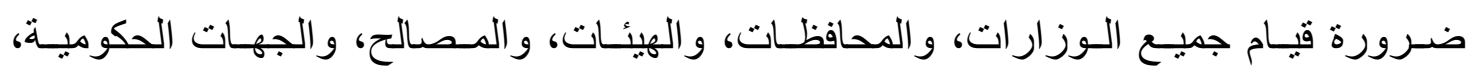

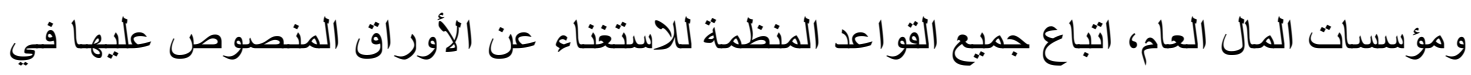

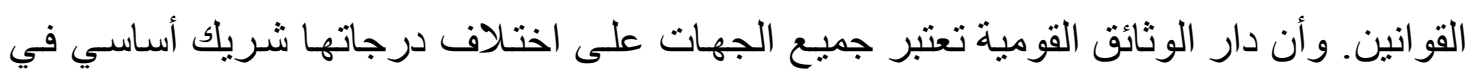

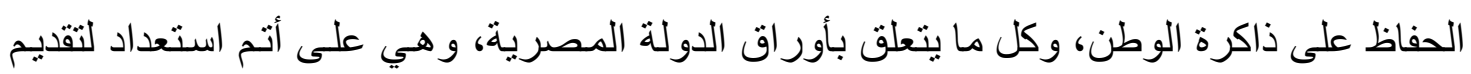

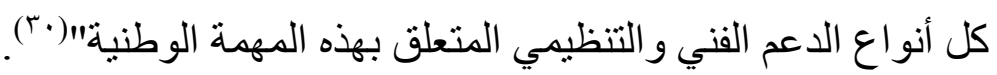

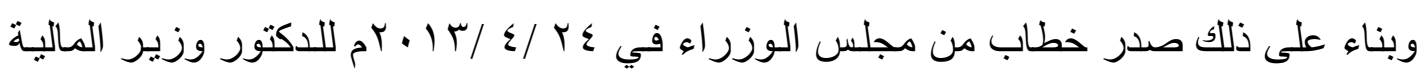

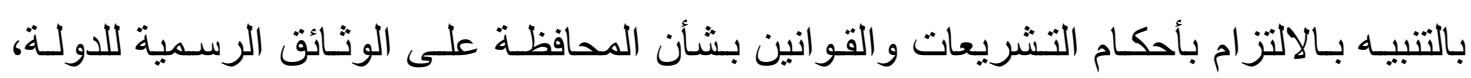

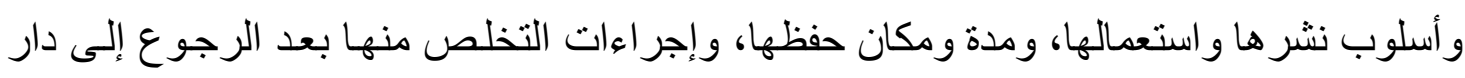

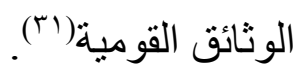

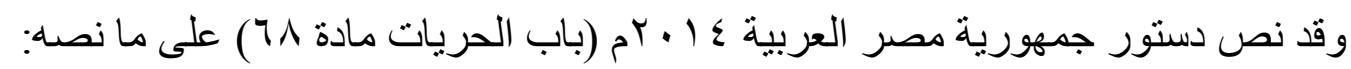

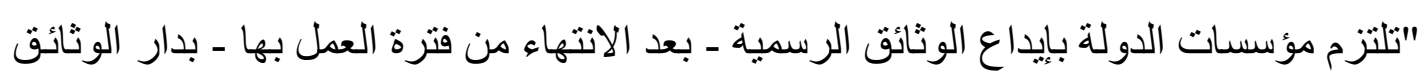

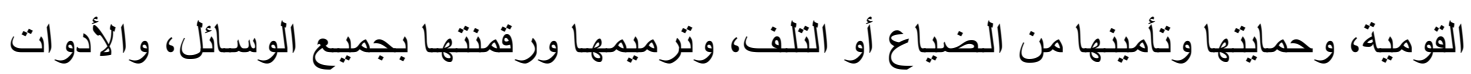
الحديثة وفقا للقانون".

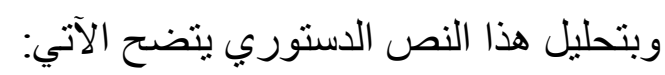

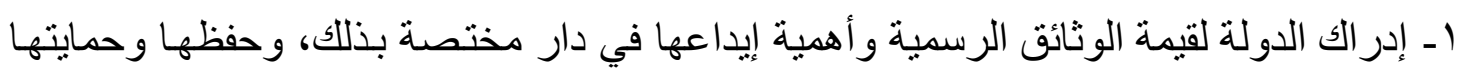
و العمل على ترميمها إذا تطلب الأمر ذلك. بالك.

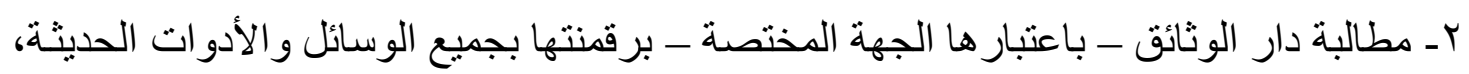

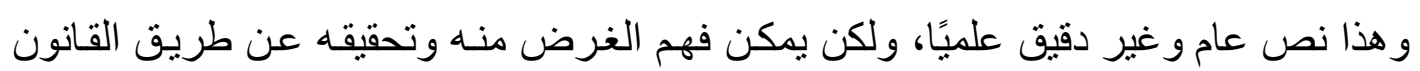

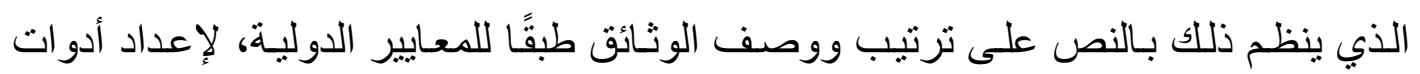

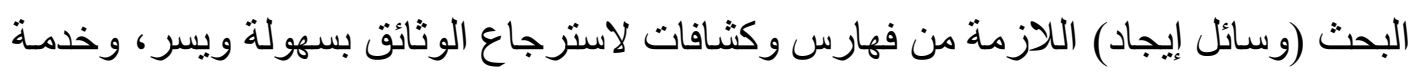

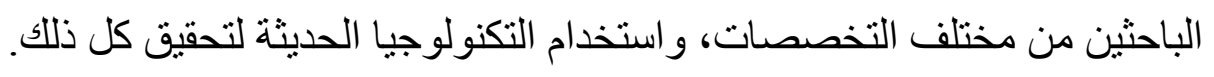

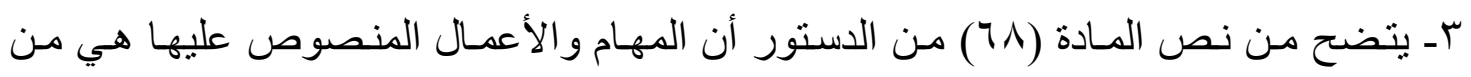

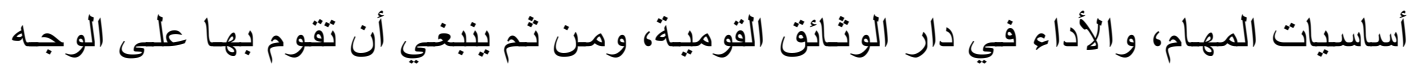


الأكمل لتطبيق المعايير الدولية، للوصول إلى جودة الأداء.

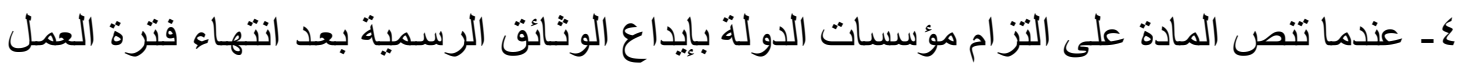

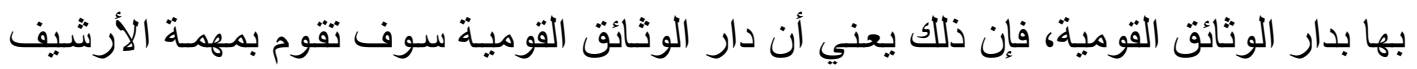
الوسيطـ إلى جانب مهمتها الأساسية- من فرز واستبعاد Triage et Elimination، ممـا يتطلب منها إنشاء إدارة مستقلة مختصة للأرشيف الوسيط تكون تابعة لها في مكان مستقل عن ون مكان الحفظ النهائي في دار الوثائق، لكي تؤدى مهام الأرشيف الوسيط وتحقق أهدافه؛ و أهمها

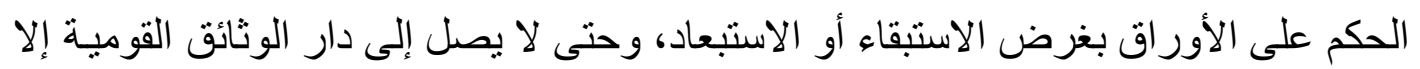

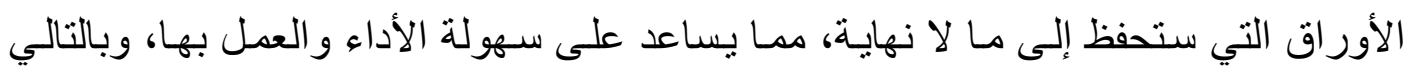
تيسير البحث العلمي دون إعاقـة وتكدس؛ حيث إن دار المحفوظـات العموميـة، والتي تتبع وزارة المالية، لا تقوم فعليًا بدور الأرشيف الوسيط ـ الذي كان من المفروض أن تقوم بـهـ

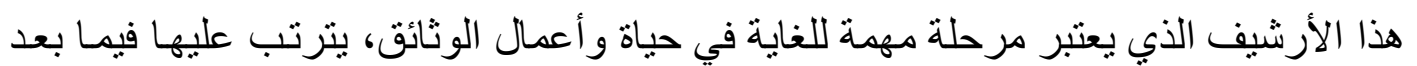
أمور عدة، أهمها إما الحفظ الجيد للوثائق الهامة التي يجب أن تستبقى باعتبار هـا ذاكرة الأمـة، أو التكدس و التر اكم و الفوضى مما يصعب ويعيق البحث العلمي و لا يساعد على تقدمه. ولعلنا نلاحظ أن علاقة دار الوثائق القومية بدستور ع ا ـ بم، تتمثل في عدة مواد مهمة مثل:

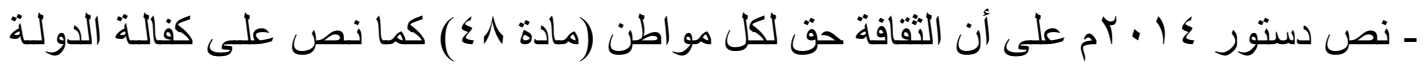

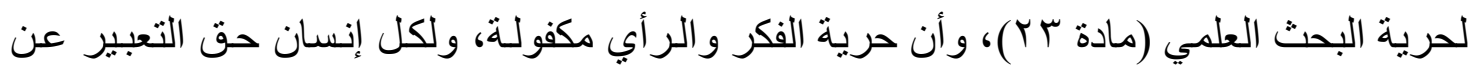
رأيه بالقول أو الكتابة أو التصوير أو غير ذلك من وسـئل التعبير و النشر (مـادة ه7)، كما تلتزم الدولة بر عاية الباحثين (مادة 7 7)، و أن المعلو مات و البيانات والإحصاءات و والوثائق الرسمية ملك ولك

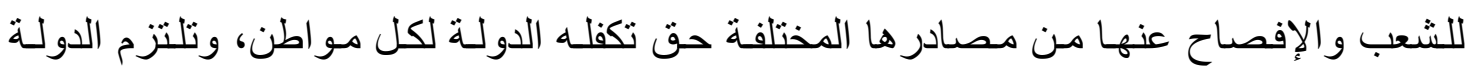
بتوفير ها و إتاحتها للمو اطنين بشفافية، وينظم القانون ضو ابط الحصول عليها، و إتاحتها وسريتها وقو اعد حفظها، والتظلـم مـن رفض إعطائهـا، كمـا يحدد عقوبـة حجب المعلومـات أو إعطـاء

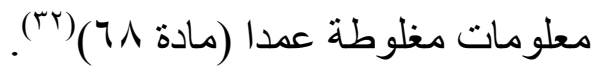
ونأمل أن هذه المواد في الدستور الجديد تطبق تطبيقًا جيدًا، وتفعل بالشكل الذي يساعد على مادى تقدم البحث العلمي، لأن الأمر الواقع الحسالي يضع قيودًا كثيرة على البحث العلمي في مجال الوثائق؛ حيث تضع دار الوثائق القومية قيودًا غير واردة في قانون حرية تداول المعلومات، أو في لي لئي

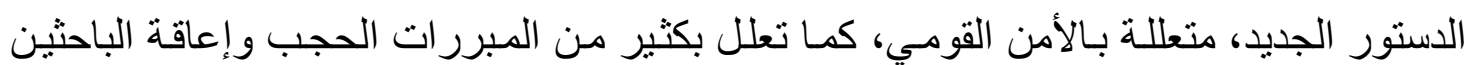
بالنظم العقيمة التي تتبعها في الإجراءات التي يجب على الباحثين إتباعها للحصول على الاطلاع أو التصوير، بينمـا يحصل أي باحث في الأرشيف البريطـي (PRO) أو الأرشيف القومي 
الفرنسي (Archives National) على حقه في الاطـلاع و التصوير بعد يوم واحد من تقديم

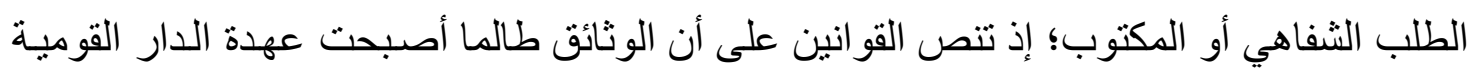

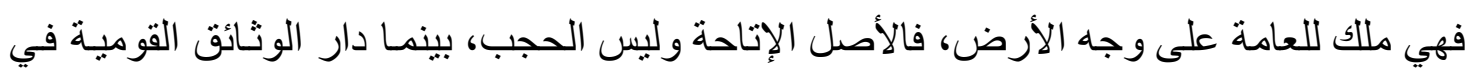
مصر تطلب من الباحث:

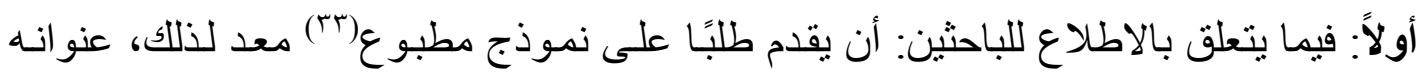

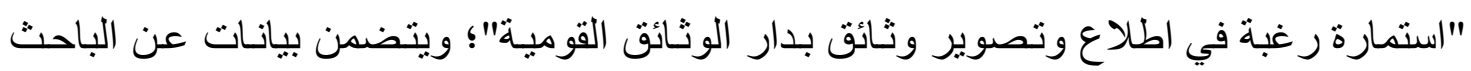

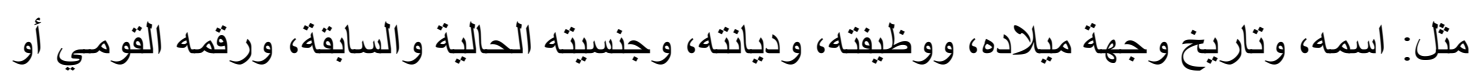

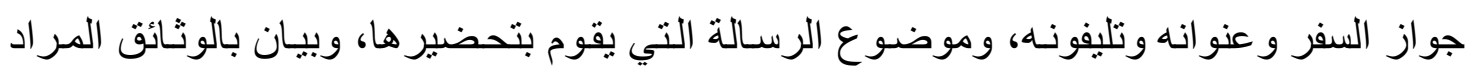

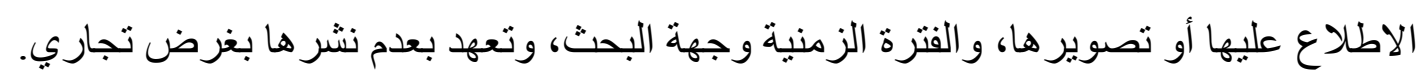

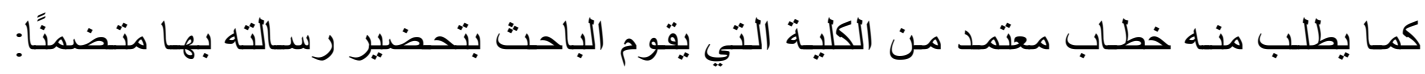

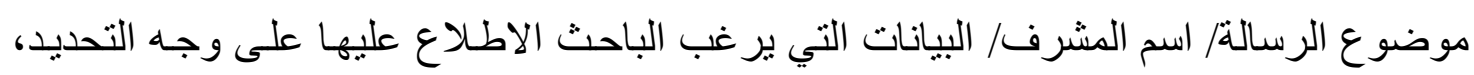
وخطة البحث/ وصورتان شخصيتان، وصورة الرقم القومي، ثم توقيع الباحث.

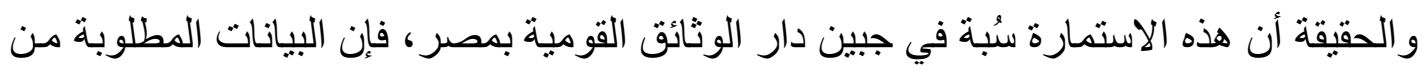

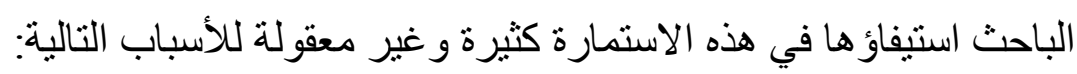

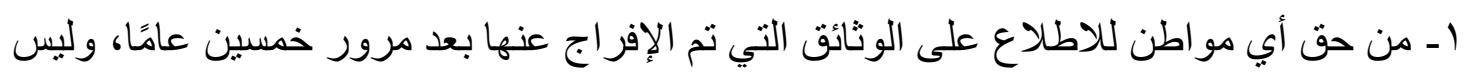
من حق أى جهة أن تطلب مبرر ات لبن للإناحة.

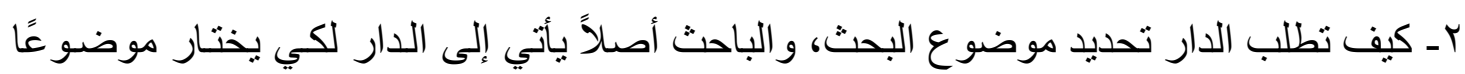

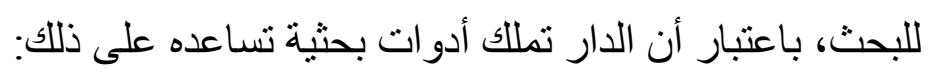

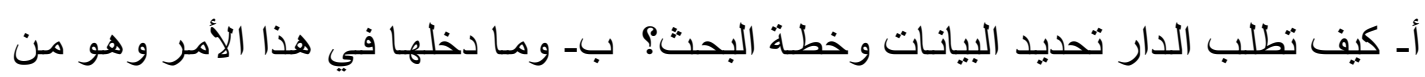

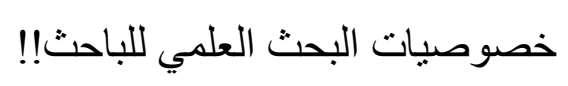

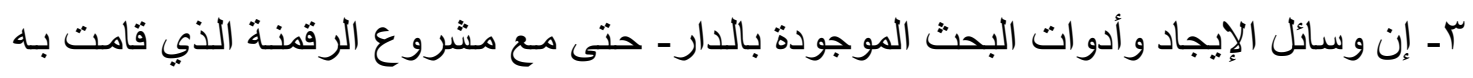

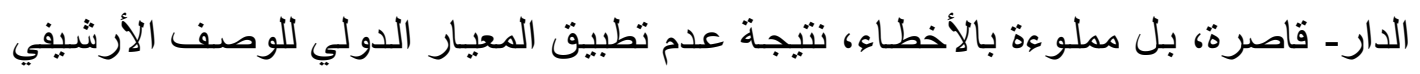

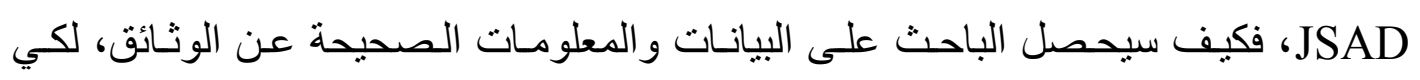
يطلابها في النموذج بالتحديد كما تنص الاستمارة.

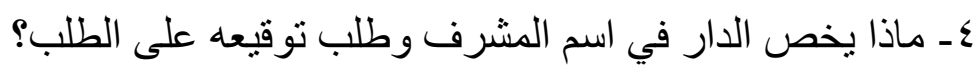
أما خطوات الحصول على التصريح فهي:

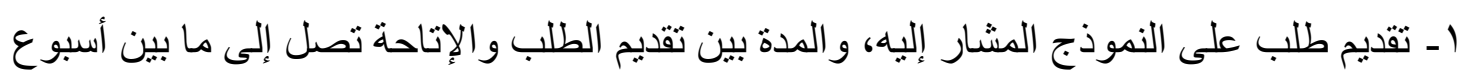

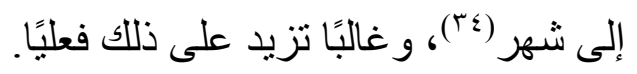


r- يقدم الطلب بمقر دار الوثائق في قاعة البحث أو المدير المسئول عن إصدار التصريح أو

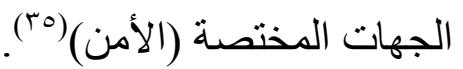

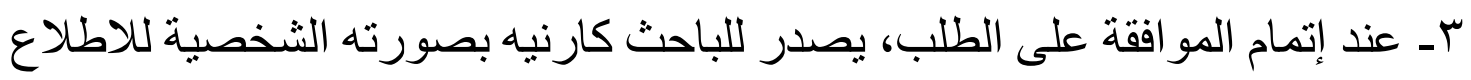

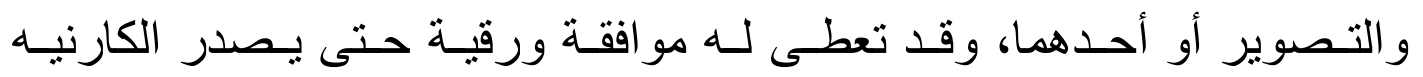
الإلكتروني.

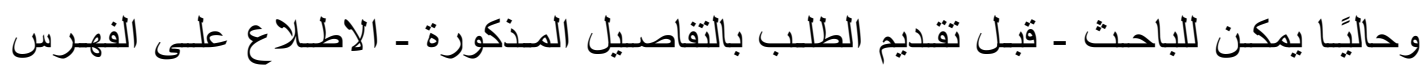

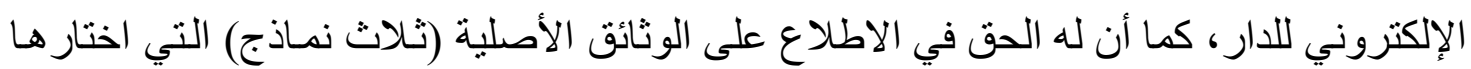

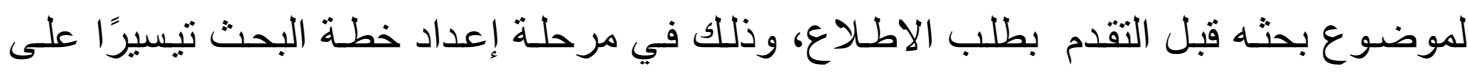
الباحثين على حد قول رئيس الدار (َr).

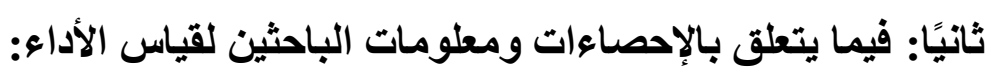

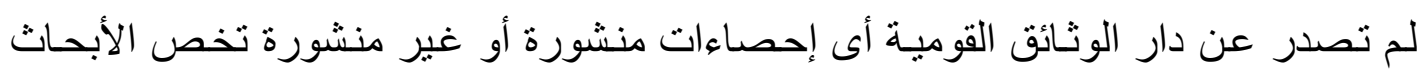

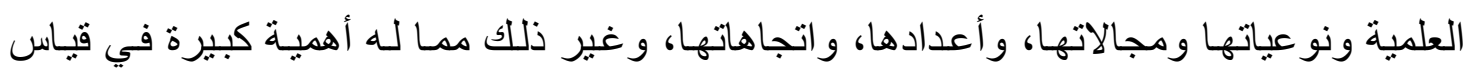

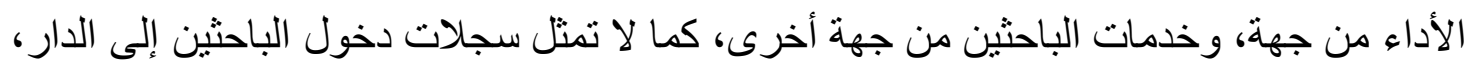

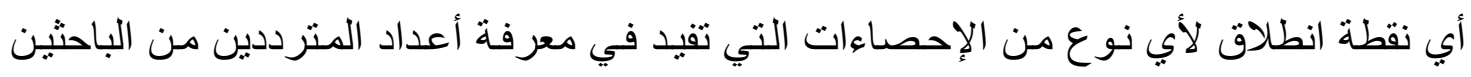

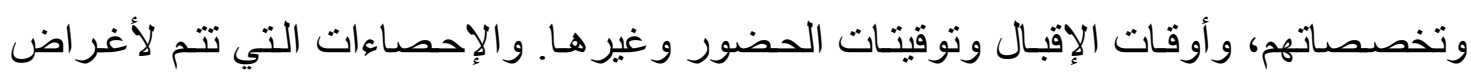

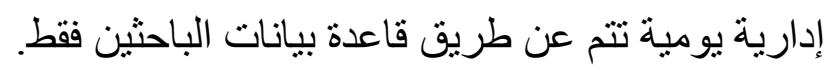
نتائج وتوصيات البحث:

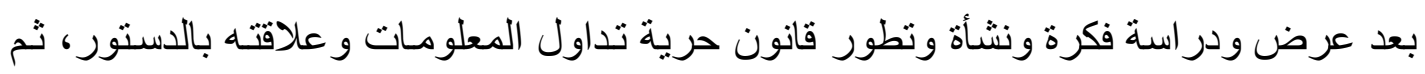
جو انب علاقة دار الوثائق بالقانون و الاستور ، يمكن التوصل ونطور لإنى إلى النتائج التالية:

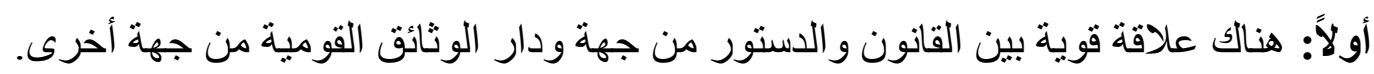

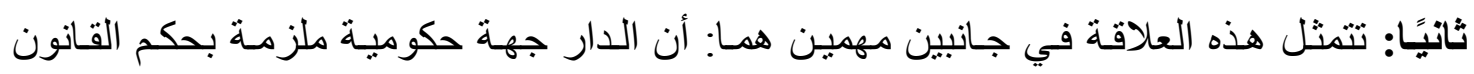

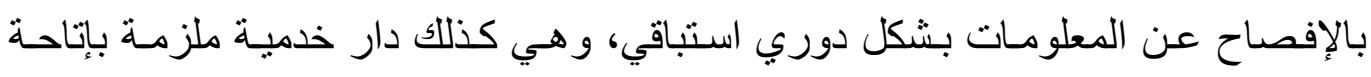

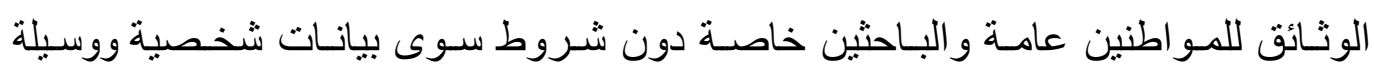

$$
\text { الاتصال بالباحثين. }
$$

ثالثًا: وجود قصور شديد في الأداء بالنسبة للجانبين اللذين تمنلهما دار الوثائق القومية.

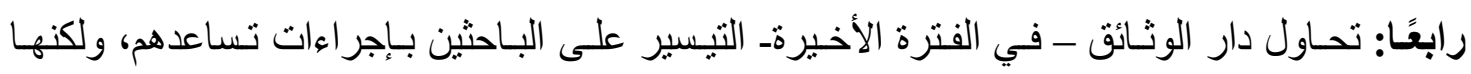
ليست كافية. خامسًا: مازلنا في انتظار صدور قانون حرية تداول المعلومات، لكي يتم تفعيل مو اده، وبالتالي 
محاسبة الجهات الحكومية - بما فيها دار الوثائق - على الأداء والتنفيذ. ويوصي البحث بالتوصيات التالية: ا ـ سرعة إصدار قانون حرية تداول المعلومات، لأننا تأخرنا كثيرًا؛ حيث كان أول اهتمـام بذلك بلك

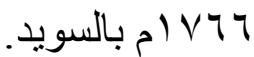
rـ أن تتولى دار الوثائق القوميـة مهامها التي أسندها لها الدستور و القانون بإنشاء دار وسيطة

تشرف عليها، ويقوم مؤهلون بأداء عمليات الفرز و الاستبعاد بها على أسس ومعايير دولية.

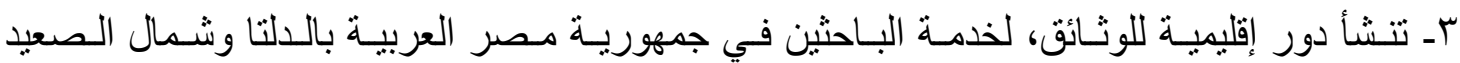
وجنوب الصعيد لتخفيف العبء عن دار الوثائق القوميـة بالقاهرة، وتكون مصادر للمعلومـات في كل أرجاء الوطن. عـ يخصص شـعار خـاص بـدار الوثائق القوميـة، يوضـع على كل مـا ينتمـي إليهـا مـن مطبو عـات و ونشور ات وغير ها، يكون لله صفة الانتمـاء إلى الدار ومقتنياتها ويعبر عن ذلك منلها مثل دور الوثائق في العالم أجمع، كما يوضع على كل ما يصدر عنها من بيانات ومعلومات و إحصاءات نص إنص عليها قانون حرية تداول المعلومات.

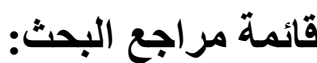

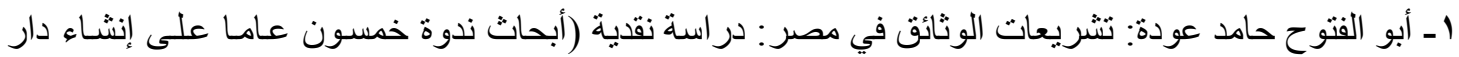

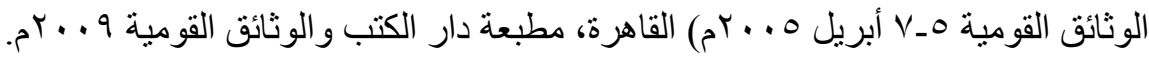

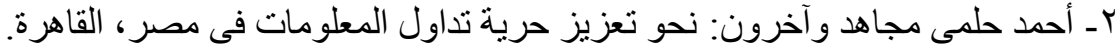

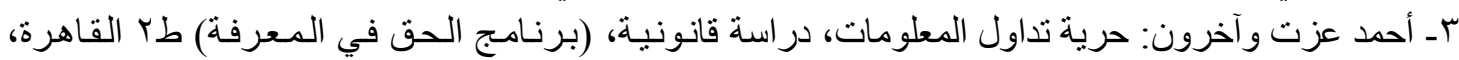
$r \cdot 1 r$ عـ ألبرت سيف حبيب: حرية تداول المعلومات كحق للمو اطن، القاهرة، الجهاز المركزي للتنظيم والإدارة، الإدارة

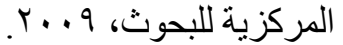
ــ أماني محمد عبد العزيز (دكتور): معايير المجلس الدولي للأرشيف في وصف كل من الوظائف (ISDF) و الجهات

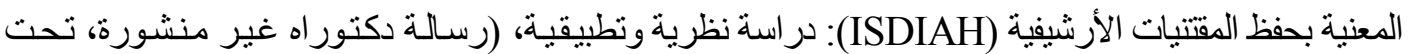
إنر اف أ.د. سلوى على ميلاد، جامعة القاهرة، ع ( ب. ج).

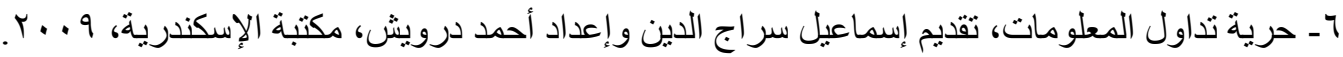

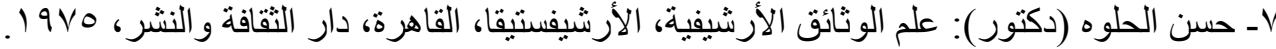

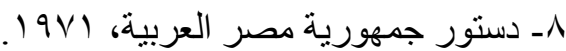

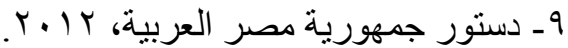

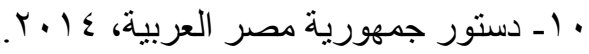

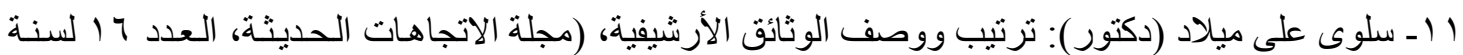
$($ ar.+$)$ r ا ـ سلوى على ميلاد (دكتور): معايير الوصف الأرشيفي وعلاقتها بجودة الأداء، (المؤتمر الخامس و العشرون 


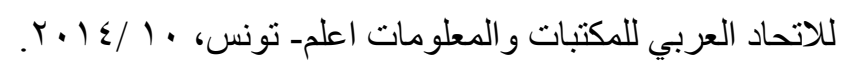

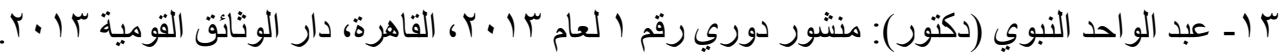

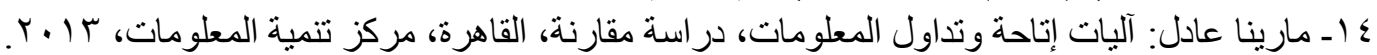

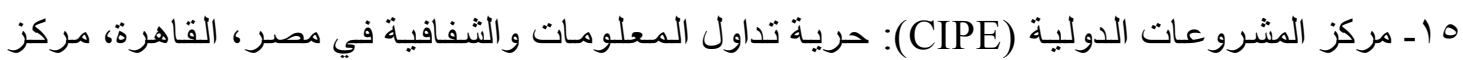

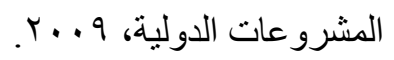

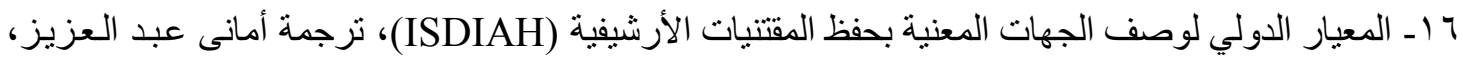

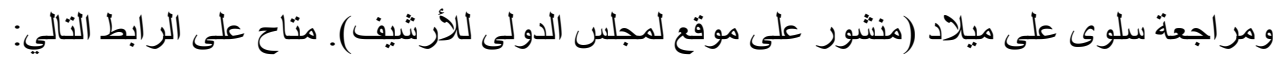
http://www.ica.org/download.php?id=2928

$$
\text { V ا ـ المعيار الدولى لوصف الوظلى الدولف (ISDF)، ترجمة أماني عبد العزيز ومر اجعة سلوى على ميلاد، (منشور }
$$

http://www.ica.org/download.php?id=2929

$$
1 \text { 1 أـ المعيار الدولى للضبط الاستتادى، ترجمة سلوى على ميلاد ضمن بحث معايير الوصف الأرشيفى وعلاقتها بجودة. }
$$

www.eipr.org/.../negsdraft-law-freedom-of-information.

20-International Standard Archival Authority Record for corporate bodies, Persons and families, $2^{\text {nd }}$ ed 2004.

21-International Standard for Desc-ribing function, 2007.

22-International standard for Descr-ibing institutions with Archival Holding, 2008.

23- Shellenberg, T.R. Modern Archives, Principles \& Techniq-ues, Chicago, The Society of American Archivists, Reissue, 2003.

$$
\begin{aligned}
& \text { الهوامش: }
\end{aligned}
$$

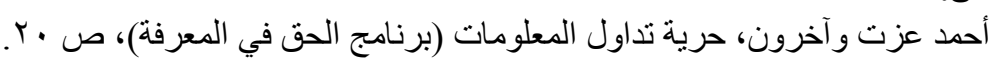

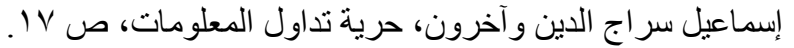

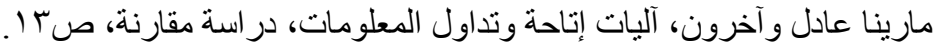

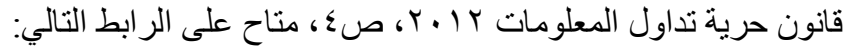

www.eipr.org/.../negsdraft-law-fre-edom-of-information.

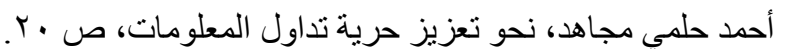

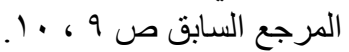

$$
\begin{aligned}
& \text { ألبرت سيف حبيب، حرية تداول المعلومات كحق للمو اطن، صآ. }
\end{aligned}
$$

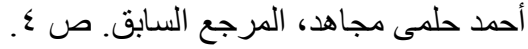

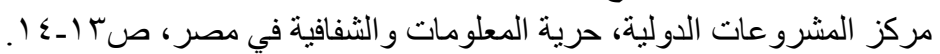

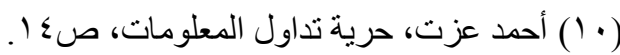

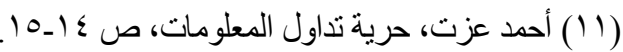

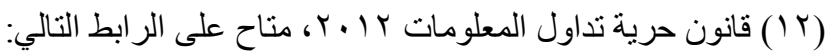

www.eipr.org/.../negsdraft-law fre-edom of information.

$$
\text { ( ا ( ) المعيار الدولى لوصف الجهات المعنية بحفظ المقتنيات الأرشيفية، متاح على الر ابط التالى: }
$$
www.ica.org/download.php?id=2928

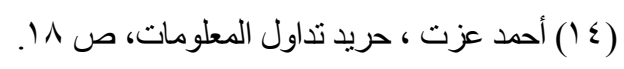




$$
\begin{aligned}
& \text { (10) أحمد حلمى مجاهد، نحو تعزيز حرية نداول المعلومات في مصر ، ص با. }
\end{aligned}
$$

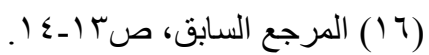

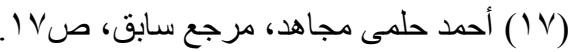

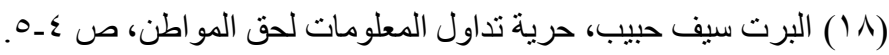

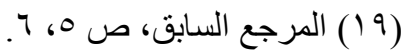

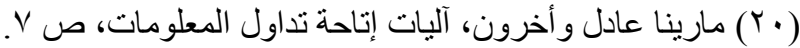

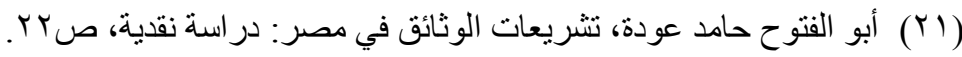

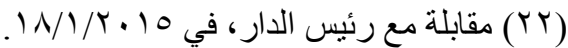

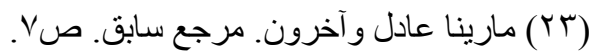

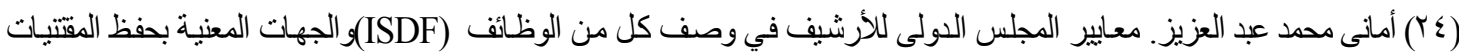

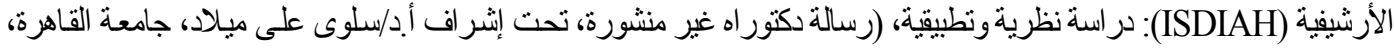

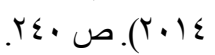

(Y0) سلوى على ميلاد، معايير الوصف الأرشيفى (المؤتمر الخامس و العشرون للاتحاد العربى تونس، ـ ( ب (Y).

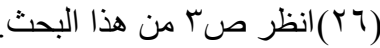

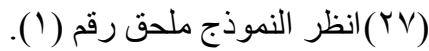

Shellenberg, T.R. Modern Archives, Principles \& Technique. ( $(Y)$ )

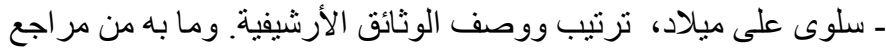

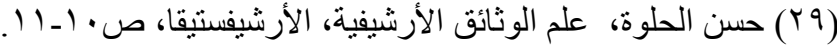

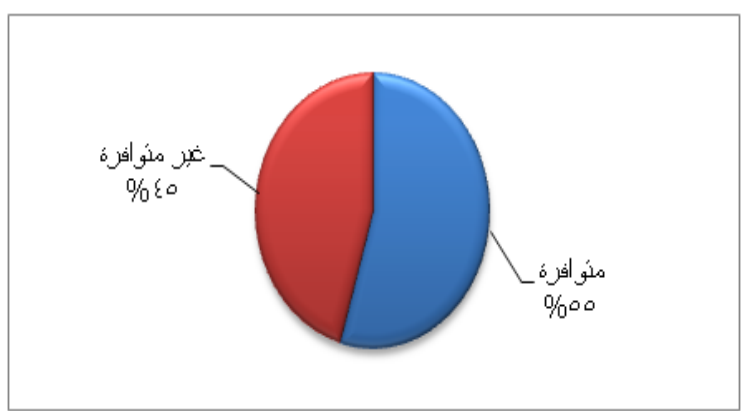

الثكل رقم (ب) مدى توافر الخطة الاستر اتيجية للمكتبة الجامعية على موقعها الإلكتروني الرسمي

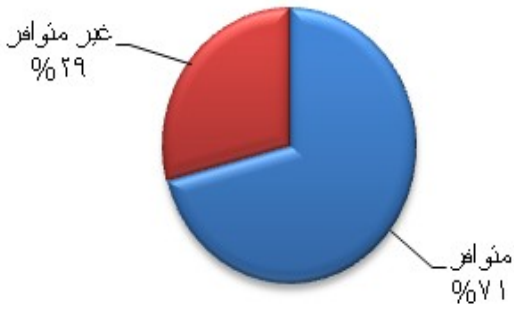

الثكل رقم (r) مدى توافر الخطة الاستراتيجية للجامعة على موقعها الإلكتروني الرسمي

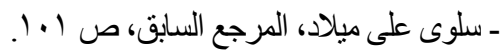

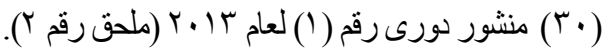

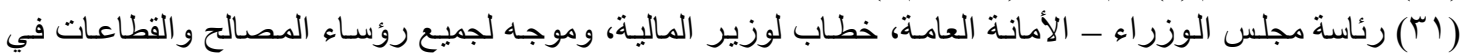

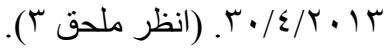

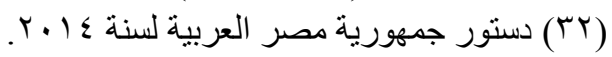

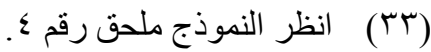

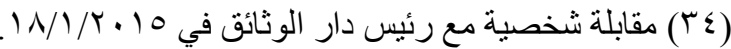

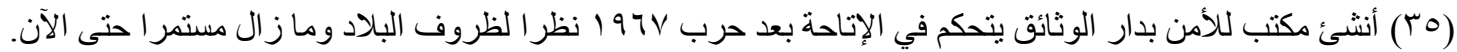

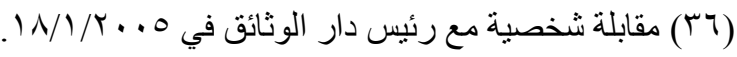

الملاحق 
ملحق رقم ( (1) طلب الحصول على صور طبق الأصل من الوثائق بدار الوثائق .

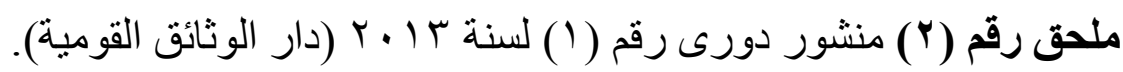

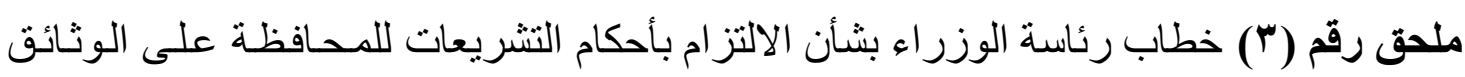

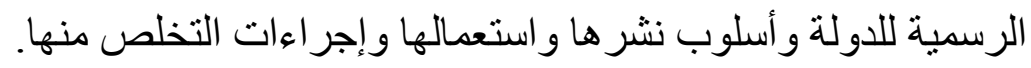

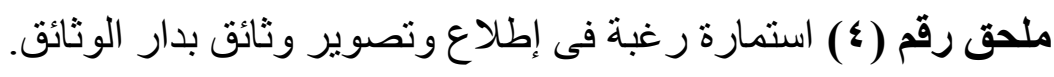

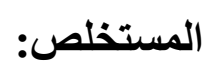

يعد وجود خطة استر اتيجية متكاملة وفعالة للمكتبة الجامعية؛ تثتنمل - ضمن مكوناتها - على ألى

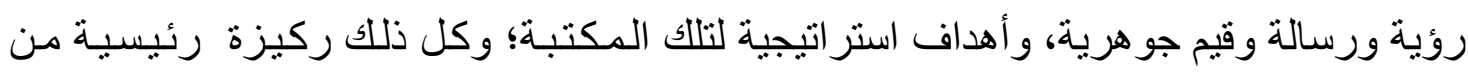

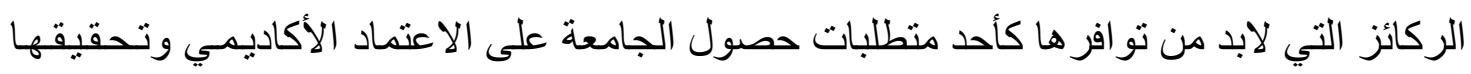

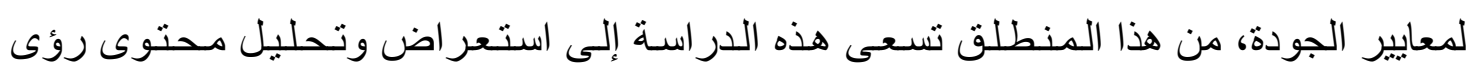

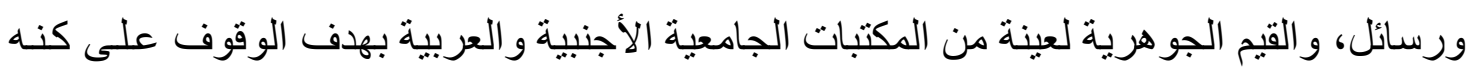

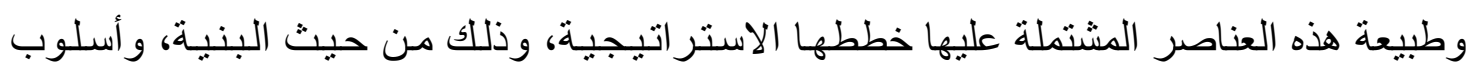

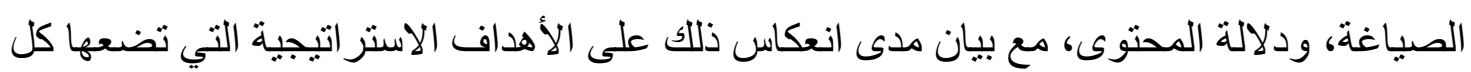

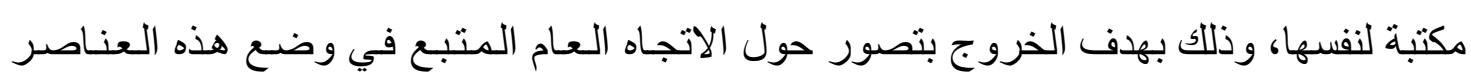

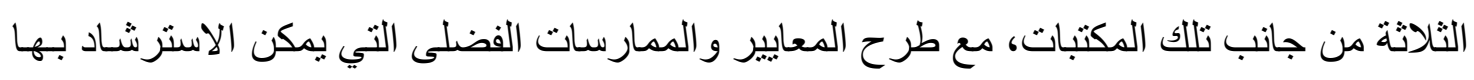

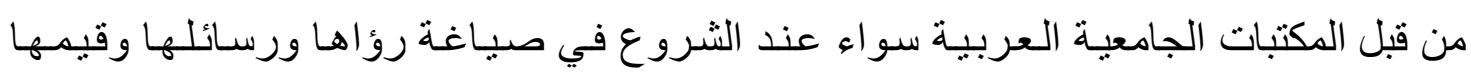

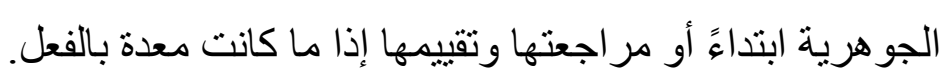

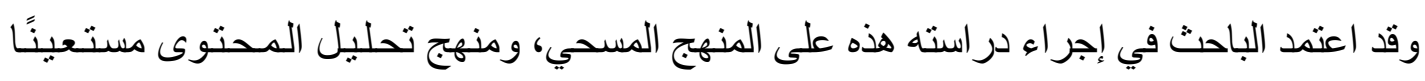

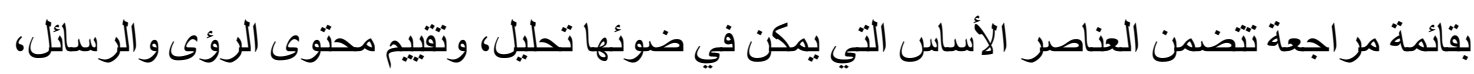

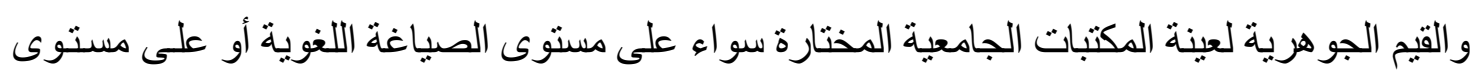

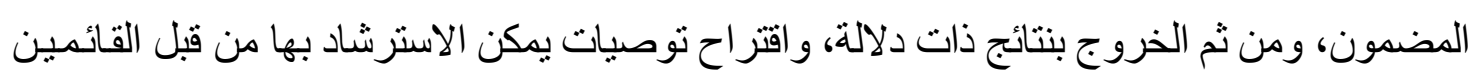
على إدارة المكتبات الجامعية ووضع خططها الاستر اتيجية في عالمنا العربي.

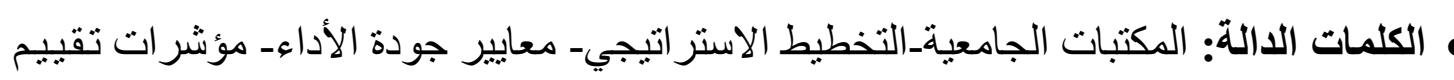
الأداء- رؤى ورسائل المكتبات. أولاً: الإطار المنهجي للاراسة: توطئة:

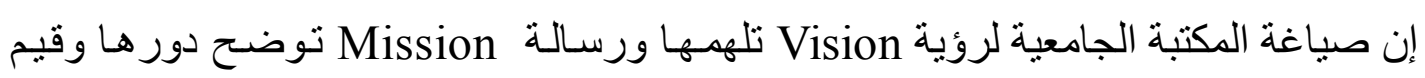

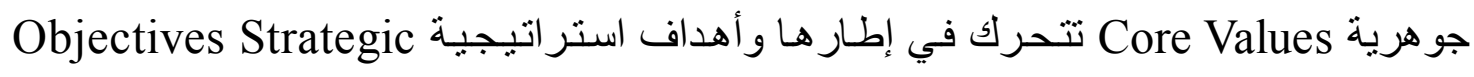


تسعى لتحقيقها ضمن خطة استر اتيجية متكاملة الأركان لا ينبغي أن يأتي من قبيل استكمال

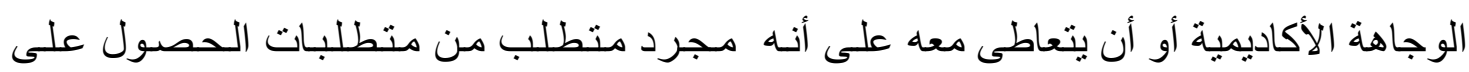

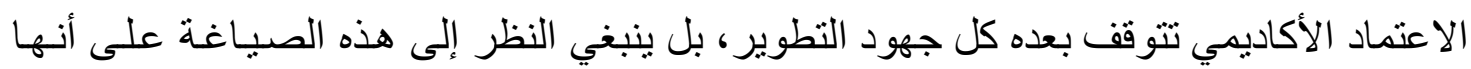

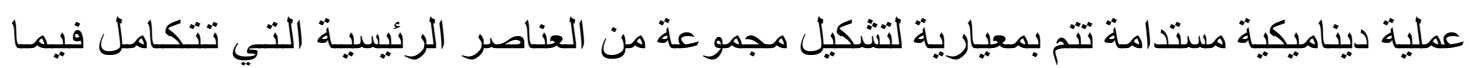

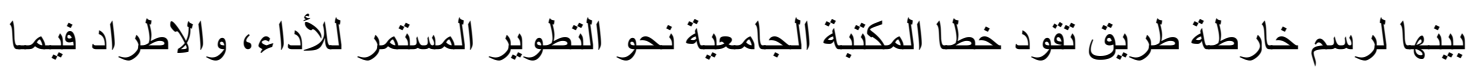

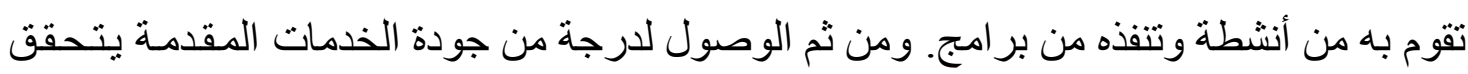

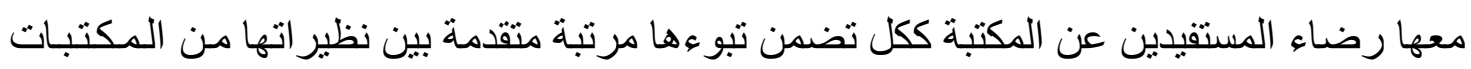

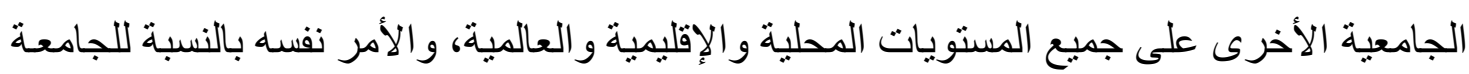

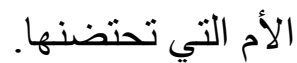

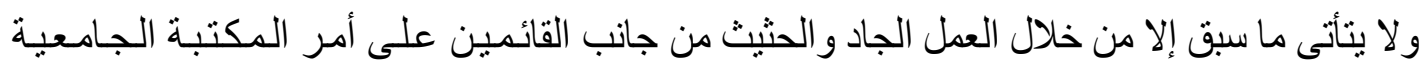

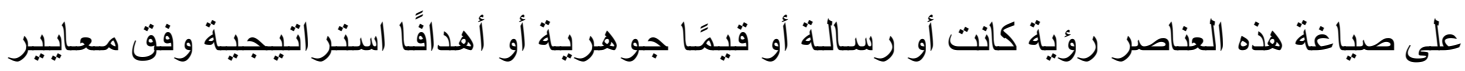

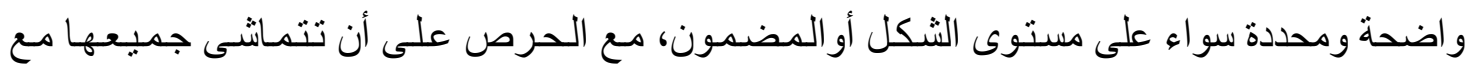

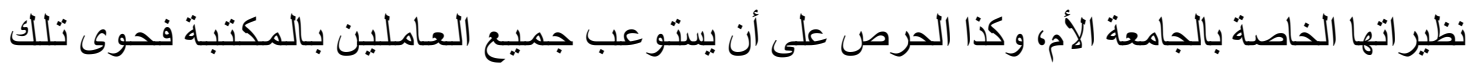

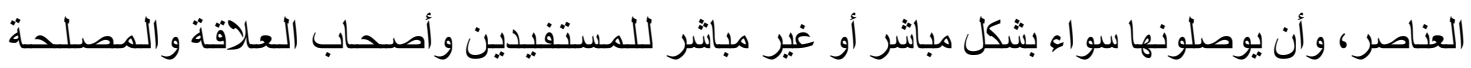
Stakeholders الجدول رقم (1) مدى توافر الرؤى والرسائل والقيم الجوهرية لاى عينة المكتبات الجامعية موضوع الدورئ الدراسة وجامعاتها

\begin{tabular}{|c|c|c|c|c|c|c|}
\hline القيم الجوهرية & الجامتبة & الجكامبة المعية & للمكتبة الجامعية الإلموقي & للجوهرية الجيم & روية ورسالة & العنصر \\
\hline rI & rᄉ & rr & $\Delta 0$ & $1 \varepsilon$ & rq & عدد المكتبات \\
\hline$\%$ rA & $\% 79$ & $\% \diamond \wedge$ & $\% 1 \ldots$ & $\%$ ro & $\% \vee$. & النسبة \\
\hline
\end{tabular}

الجدول رقم (؟) مدى توافر الرؤى والرسائل و القيم الجوهرية جميعاً أو منفردة

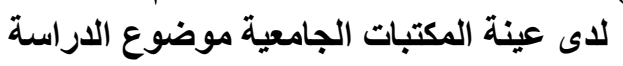

\begin{tabular}{|c|c|c|c|c|c|c|c|}
\hline والقيم الجوهرية والرسالة & الجوهرية فئة الجيم & الجوهرية & والرسالية & الجوهرية & فقط & فقط & العنصر \\
\hline iv & $r$. & 11 & r. & ri & rs & ry & عدد المكتبات \\
\hline$\%$ & $\%$ & $\%$ rr & $\% 00$ & $\%^{r \Lambda}$ & $\% 79$ & $\% \circ \wedge$ & النسبة \\
\hline
\end{tabular}


من هذا المنطلق تحاول هذه الدر اسة تناول هذه الإشكالية تناو لاً منهجيًا من خلال استعر اض وتقييم

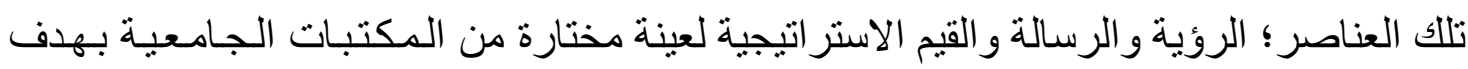
الوقوف على التوجه العام في صياغتها والقواسم المشتركة بينها واستجلاء مدى الالتز ام بالمعايير في صياغة كل منها.

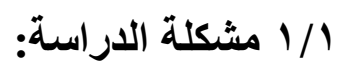
تتلخص مشكلة هذه الار اسة في أنه على الرغم من أهمية وجود رؤية ورسالة وقيم جو هريـة،

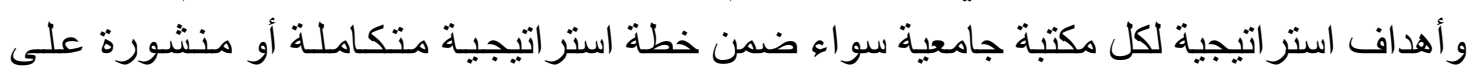

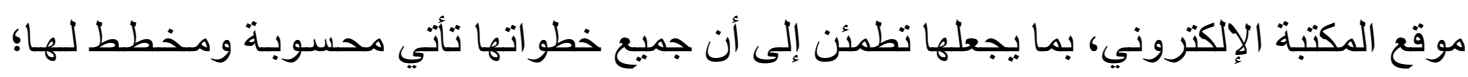

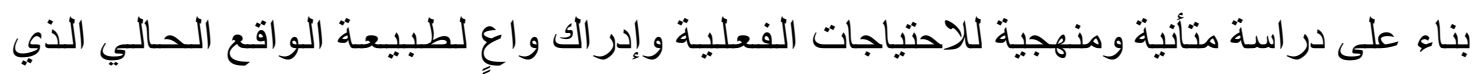

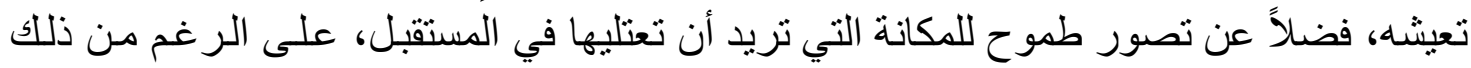

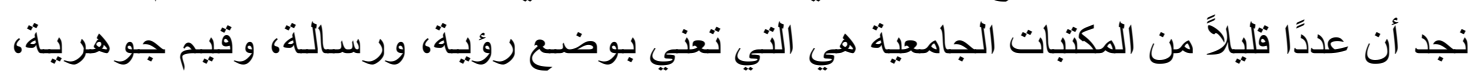

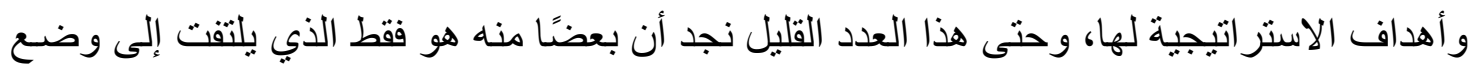

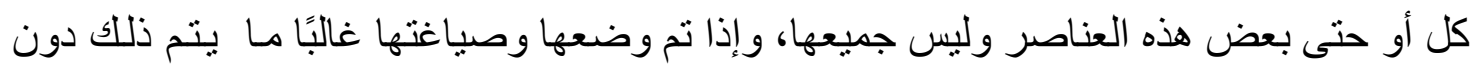

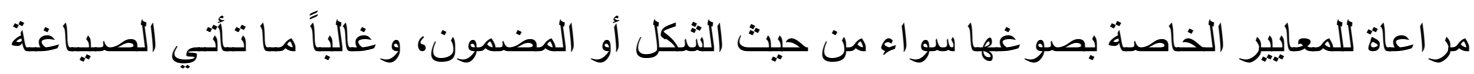

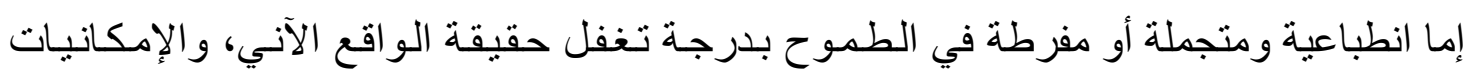

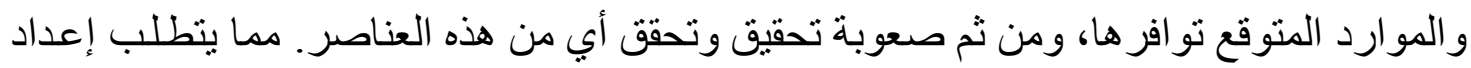

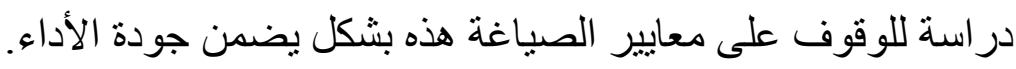
r// ب أهمية الاراسة: تنبع أهمية موضوع هذه الدر اسة من منطلق أن توفير منطلبات الاعتمـاد الأكاديمي، و إحراز

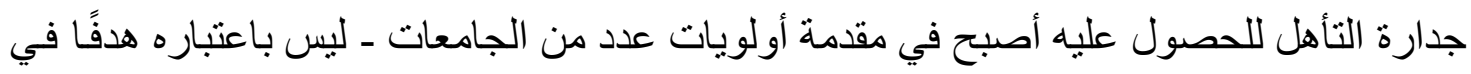
حد ذاته - و إنما بوصفه طريقًا للاطمئنان إلى مستوى جودة العملية التعليمية و البحثية برمتها، وكذا هـات

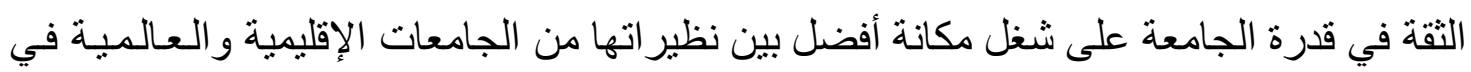

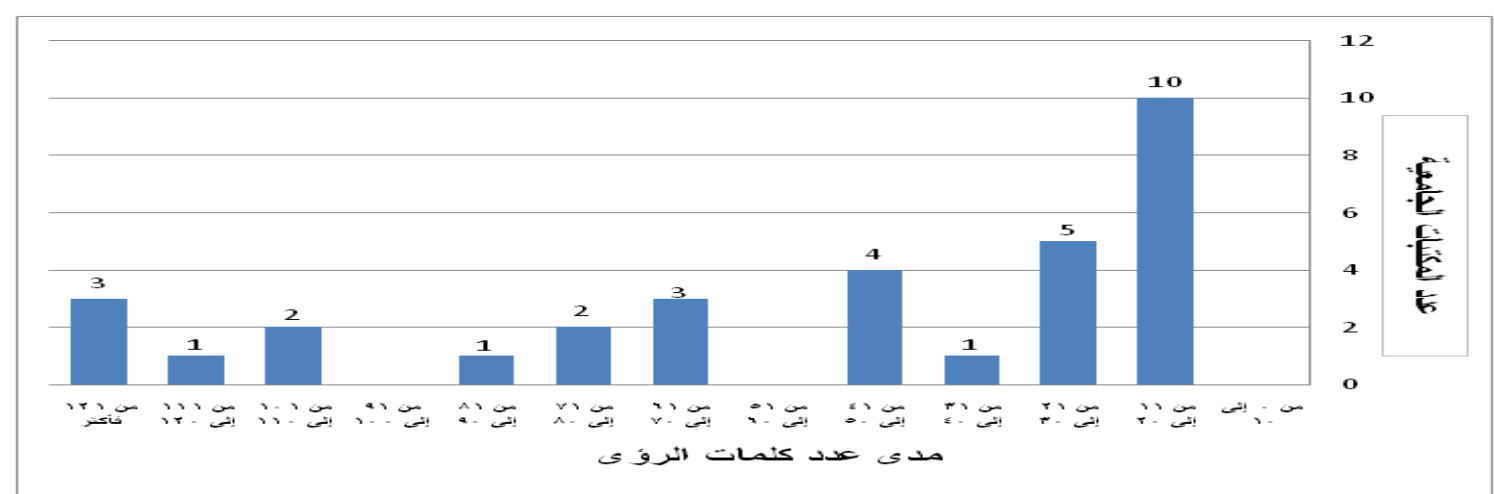

الثكل رقم (ץ) الخاص بييان مدى عدد الكلمات المفتاحية في رؤى عينة المكتبات الجامعية موضوع الاراسة 


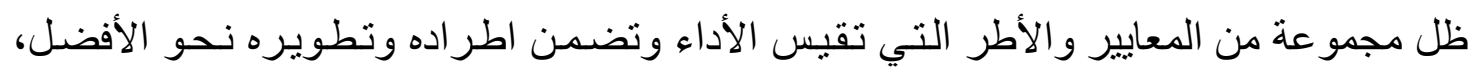

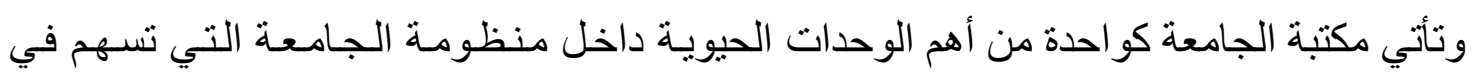

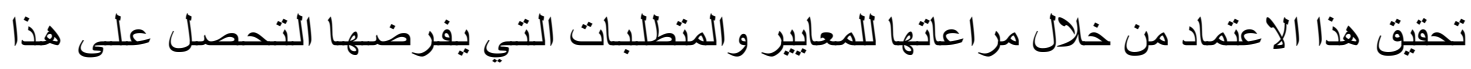
الاعتماد. وتركيزًا على ضرورة وجود رؤية ورسالة وقيم جوهرية للجامعة نجد أن كثيرًا مـن المعايير

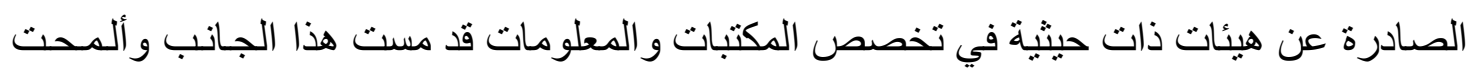

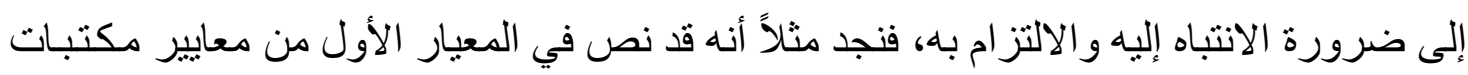

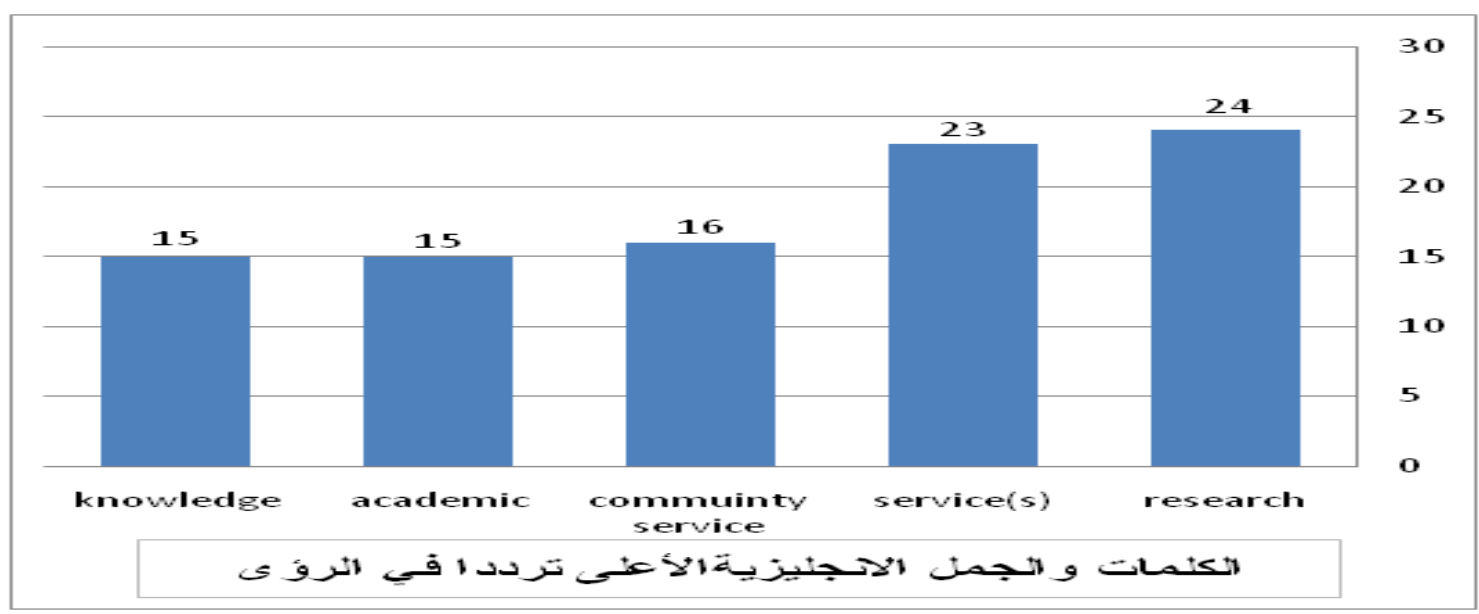

الثكل رقم (r) الخاص بييان الكلمات والجمل الإنجليزية الأعلى ترددًا

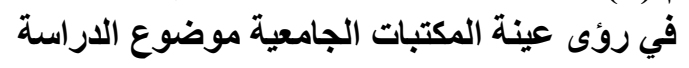

الكليات الكندية التي أعدتها الجمعية الكندية لمكتبات الكليات، و الجـامعات CACUL على أنهه"

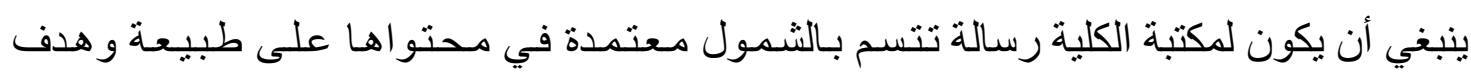
المؤسسة التعليمية التي تتبعها جامعة كانت أو كلية أو معهد]" (Libraries ACRL). كذلك جاء ضمن مؤشر ات تقييم الأداء KPIs التي اشتمل عليهـا دليل معايير المكتبـات في فئسي

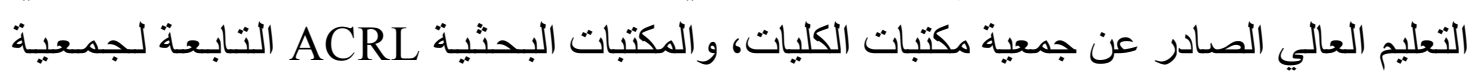
المكتبات الأمريكية ALA "ضرورة تطوير المكتبة لمخرجات تتماشى معى متطلبـات الاعتمـاد

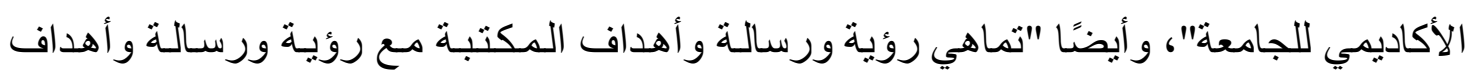
الجامعة".

و على الصعيد العربي نجد أنه قد أثنير في المعيار العربي الموحد للمكتبات الجـامعيـة الصـادر

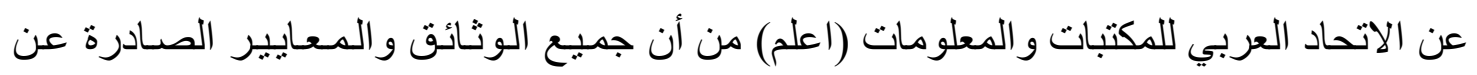

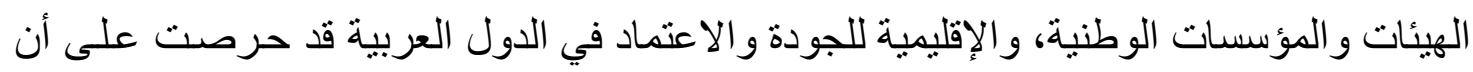
تكون المكتبة أحد المحاور الرئيسية من محاور ضمان جودة المؤسسة الجامعية، وإن اختلفت هذه فئه 
المعايير في وضع المكتبة الجامعية داخل المتعددة لضمان الجودة، و إن كان معظمها قد نم وضعها

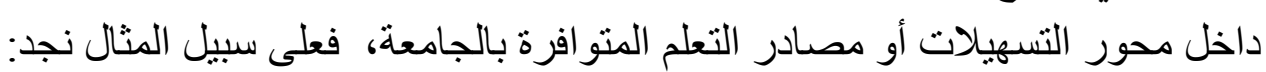

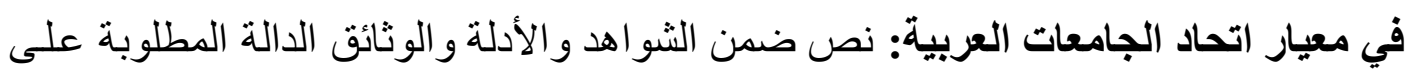

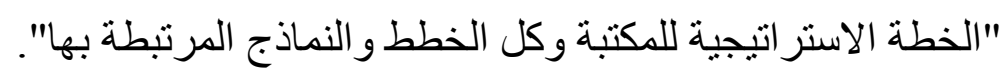

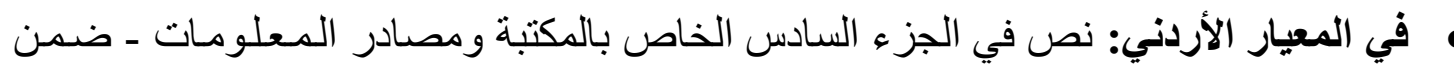

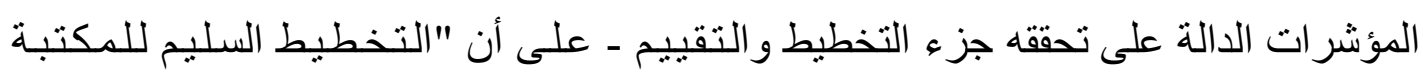
ومصادر المعلومات يدعم الوظائف التدريسية و التعليمية للمؤسسة....".

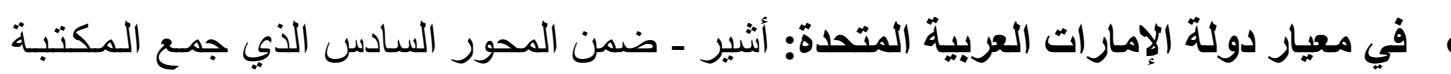

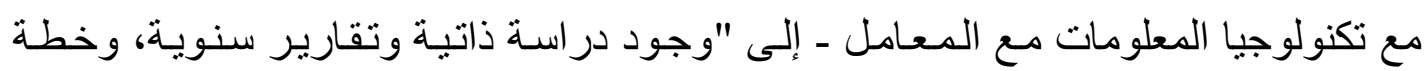

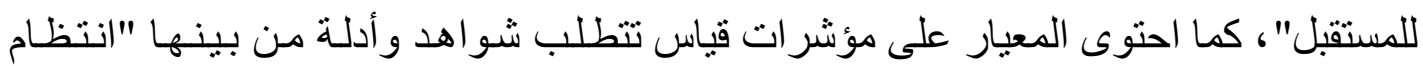
وضع خطط استر اتيجية وتقارير سنوية".

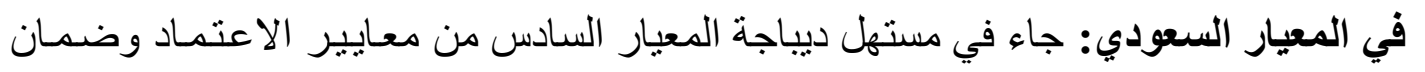

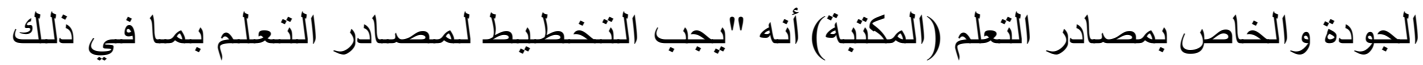

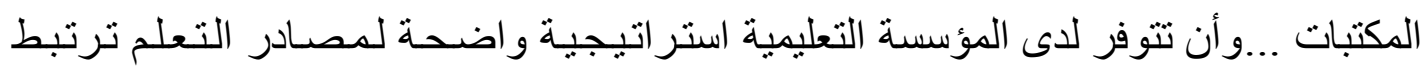

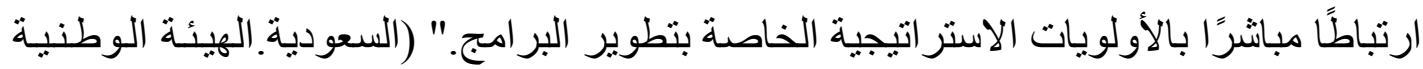

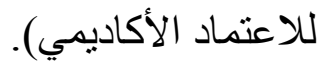
نخلص مما سبق إلى أن وضع رؤية ورسالة وقيم جوهرية يعد مكونًا أساسيًا ضمن التهن التخطيط

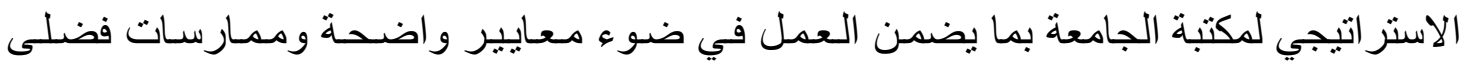

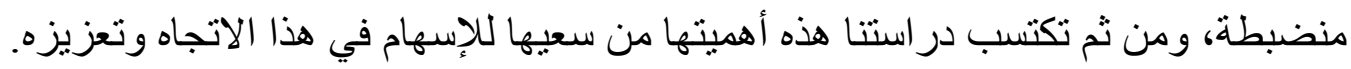

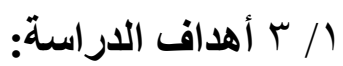

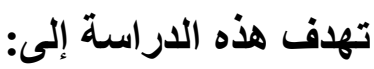

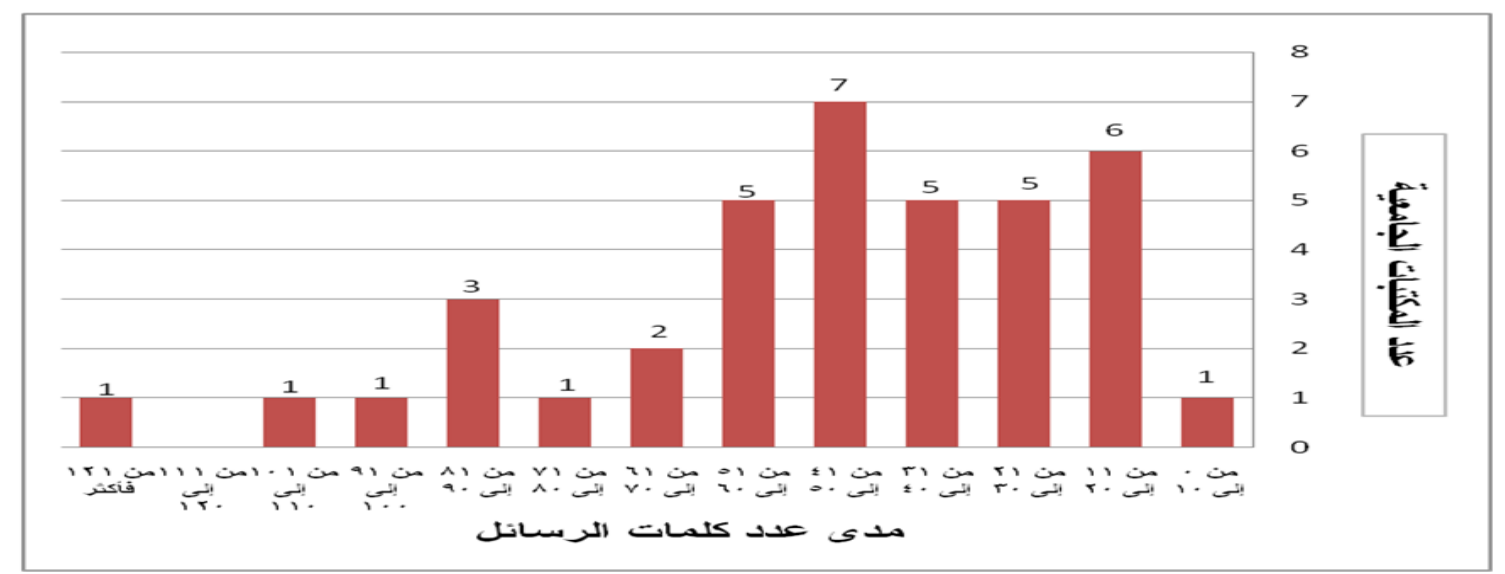

الثكل رقم (؛) الخاص ببيان مدى عدد الكلمات الدفتاحية في رؤى عينة المكتبات الجامعية موضوع الدراسة 
حصر وتحليل شكل ومحتوى رؤى ورسائل، و القيم الجو هرية لعينة من المكتبات الجامعية.

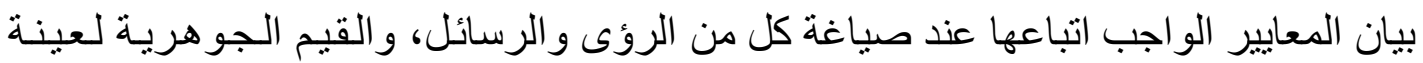
المكتبات الجامعية. الخروج بمؤشر ات كمية حول مدى مر اعاة عينة المكتبات الجـامعيبة موضوع الدر اسـة لتلك المعابير . تقديم مقترحات تعزز توجهات الالتز ام بمعايير صياغة تلك الرؤى و الرسائل و القيم وتسهـم في توسيع نطاق هذا الالتز ام من جانب المكتبات الجامعية.

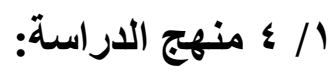

اعتمد الباحث في تناوله لمشكلة الدر اسة على المنهجية الآتية:

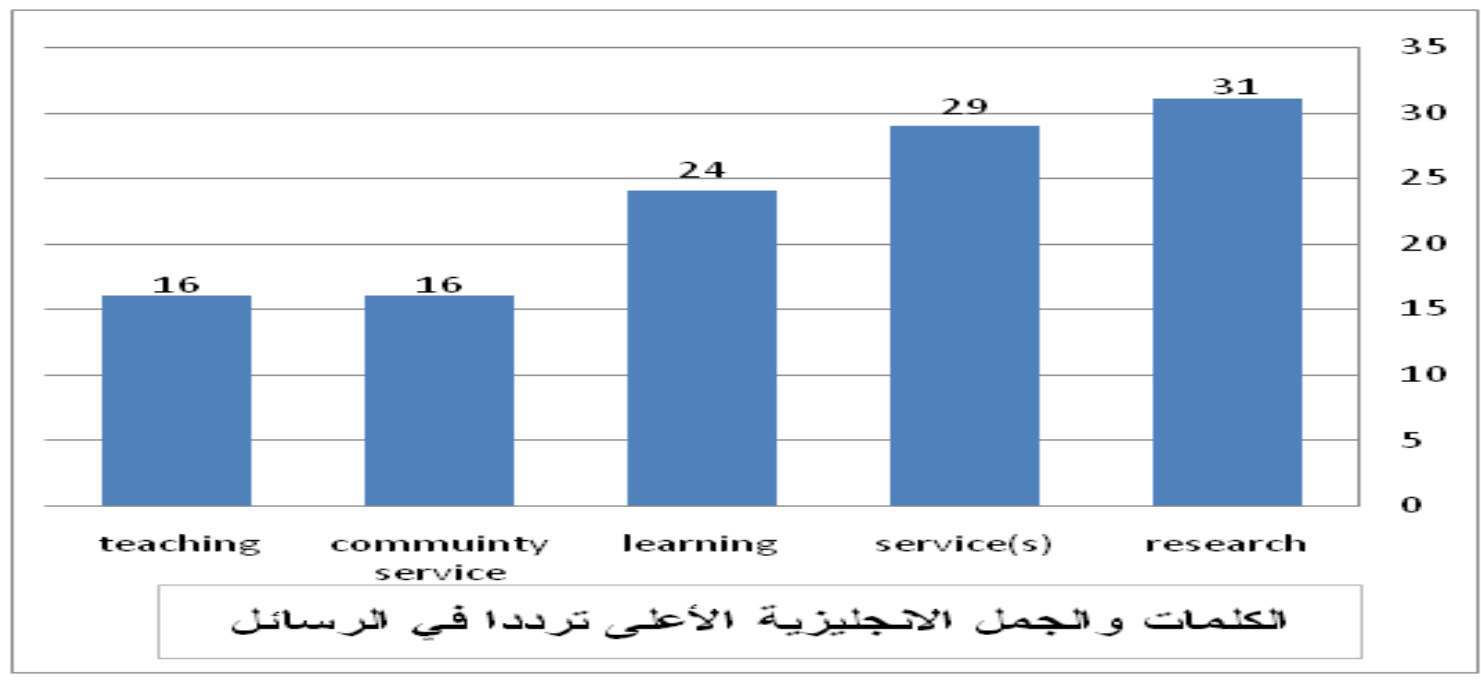

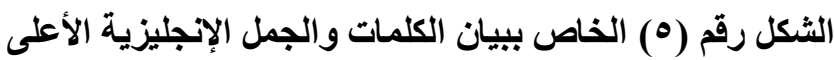

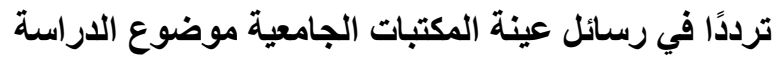

الجاتب النظري: تمثل في المراجعة الثاملة لما أمكن التوصل إليه من نتاج فكري منشور

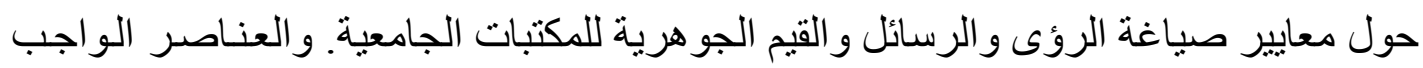
تو افرها في كل منها. الجانب التطبيقي: اعتمد على منهجين؛ المنهج المسحي الذي يقوم بـالأسـس على رصد ظاهرة أو

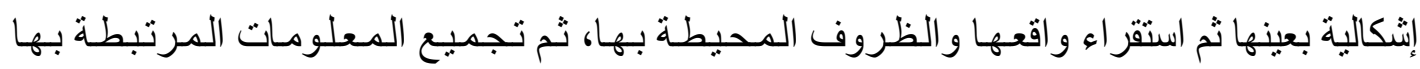

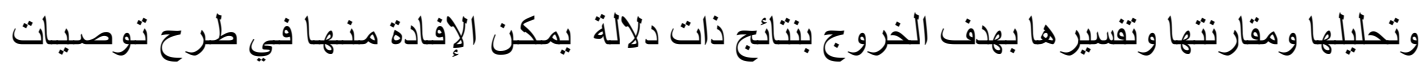

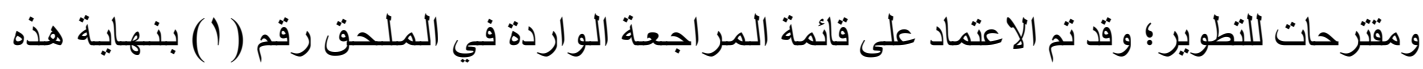

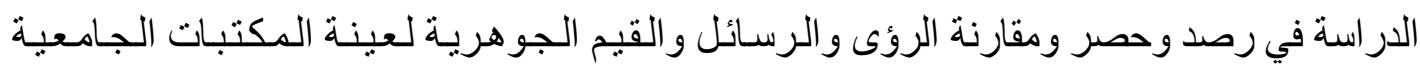
موضوع الدر اسة سو اء المشتملة عليها خططها الاستر اتيجية أو الواردة في موقعهـا الإلكتروني أو لوني 
الموقع الإلكتروني للجامعة الأم التي تتبعها. ومنهج تحليل المحتوى (المضمون) الذي استخدم

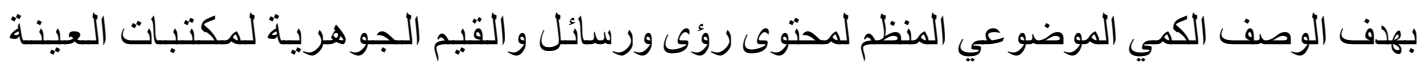

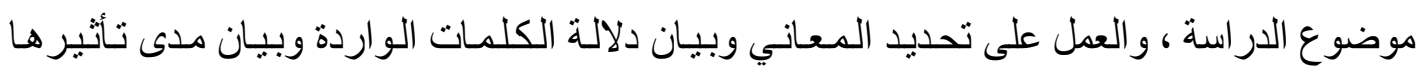

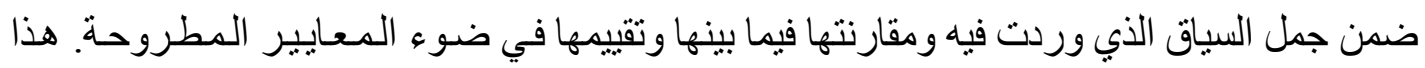

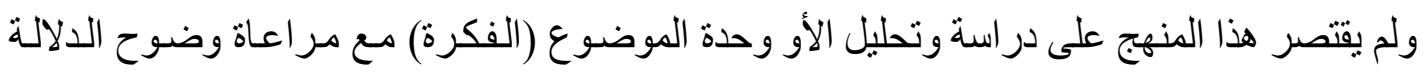

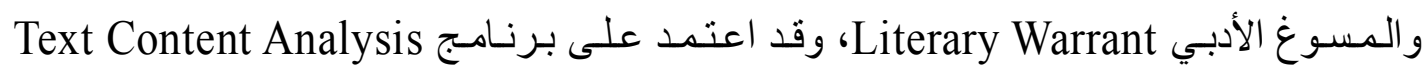

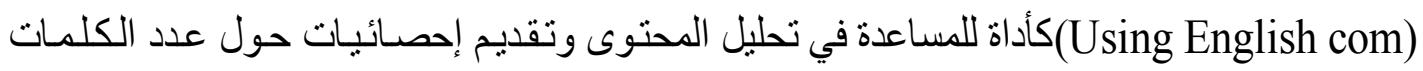
و الجمل ومدى تو اتر ها، مع قبام الباحث بقر اعة المحتوى مرة أخرى قر اعة متأنية للتأكيد على دلاعلة

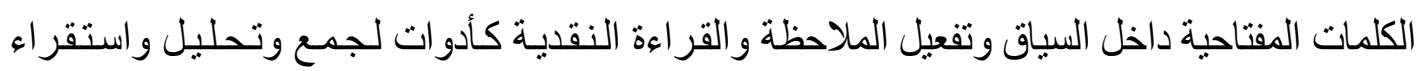
البيانات.

محتوى فحسب و إنما شمل أيضًا الجو انب الثكلية، سو اء على مستوى وحدة (الكلمـة/الجملـة)

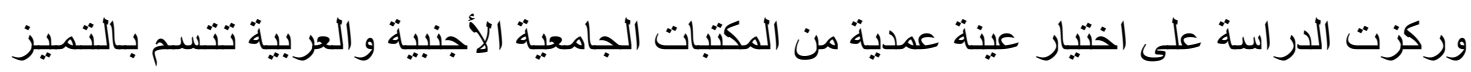

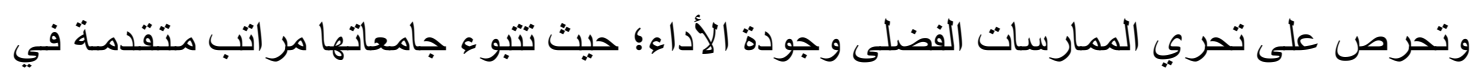

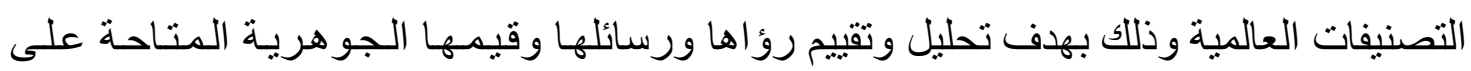
موقعها الإلكتروني، و هي مكتبات الخمسين جامعة الأولى في قائمة تصنيف جامعة شنغـهاي لـعام

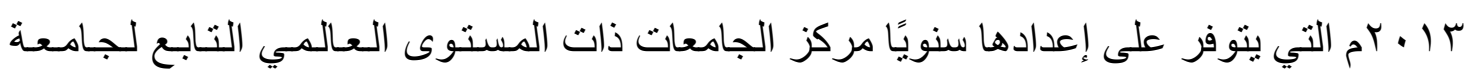
Center for World-Class Universities at Shanghai Jiao Tong شنغهاي جيو تونج University

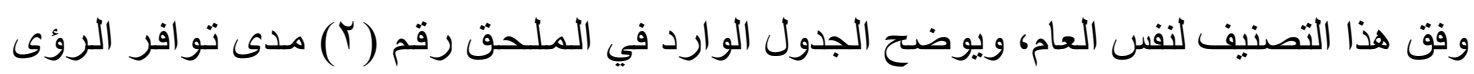

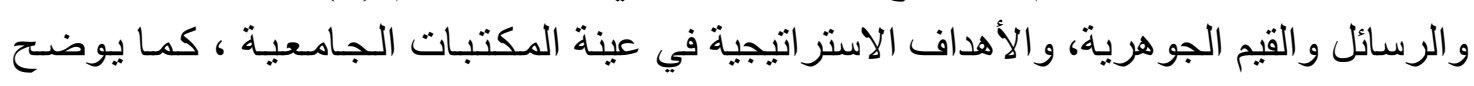

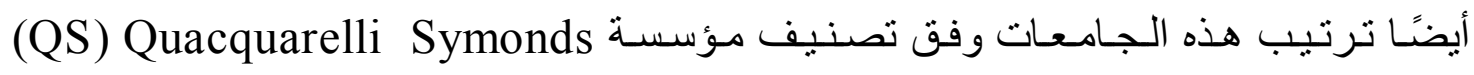

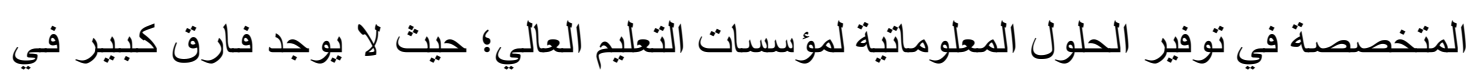
ترتيب الجامعات على هذين التصنيفين، ويأتي التفاوت في المرتبة نتيجة اختلاف المعايير التي

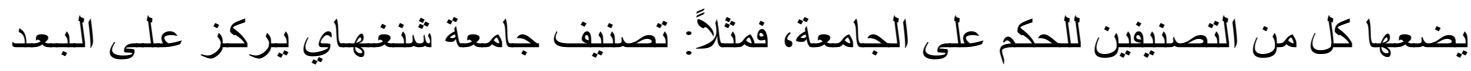

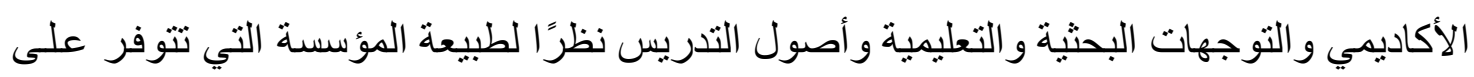
إعداده، في حين يركز تصنيف QS بحكم طبيعة المؤسسة التي تقف ور اعه على تقنيات المعلومات

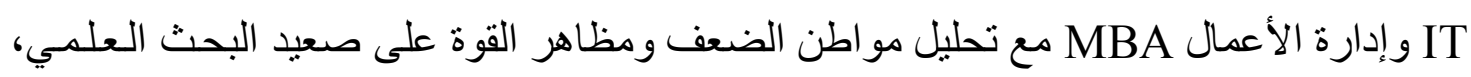

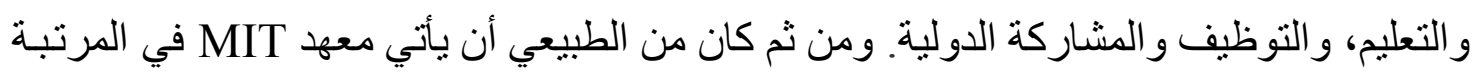

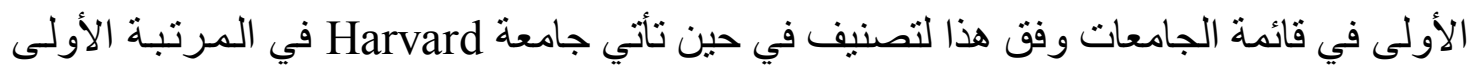




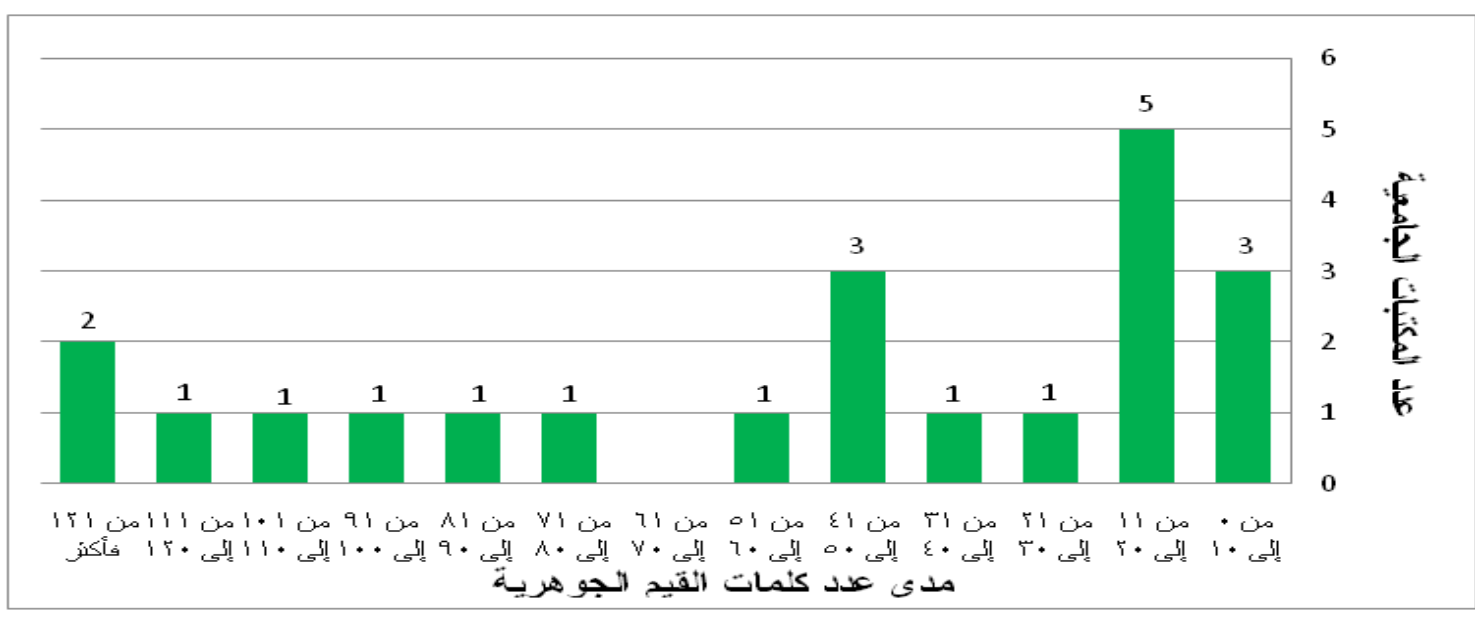

الثكل رقم (†) الخاص ببيان مدى عدد الكلمات المفتاحية في القيم الجوهرية

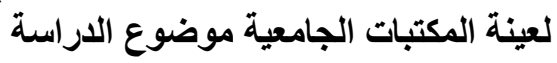

وفق تصنيف جامعة شنغهاي.

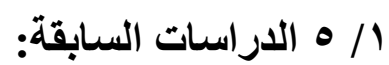

من خلال مر اجعة النتاج الفكري العربي و الأجنبي حول موضوع الدراسة استة في كل من قو اعد

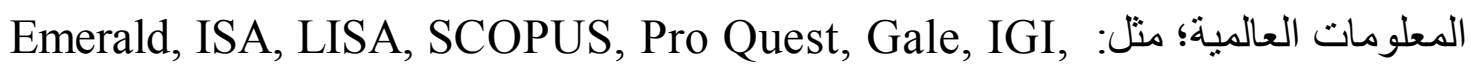

and EBSCO

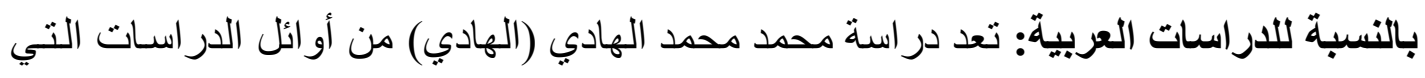

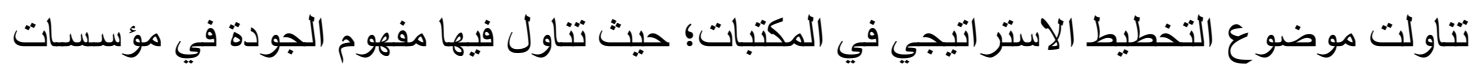

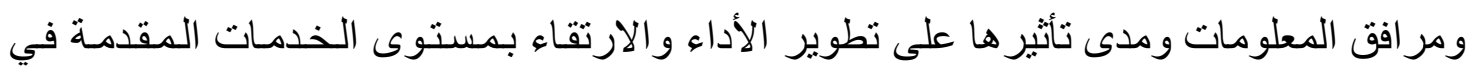

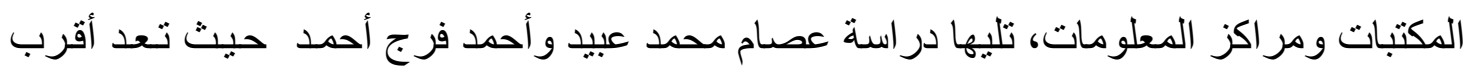

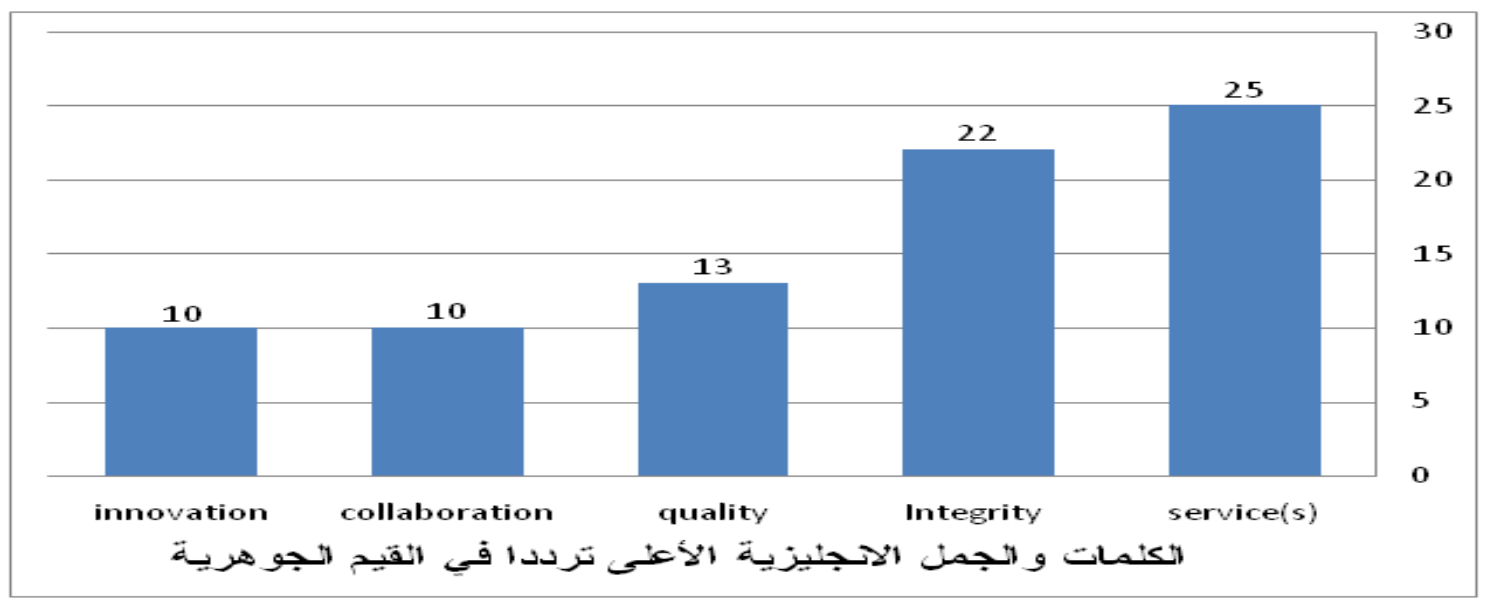

الثكل رقم (V) الخاص بييان الكلمات والجمل الإنجليزية الأعلى ترددًا

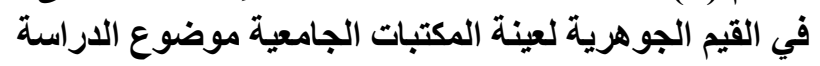




$$
\text { الأعمال لموضوع هذه الدر اسة . }
$$

ويحسب لها فضل السبق في التناول؛ حيث استعرض الباحثان مفهوم التخطيط الاستر اتيجي

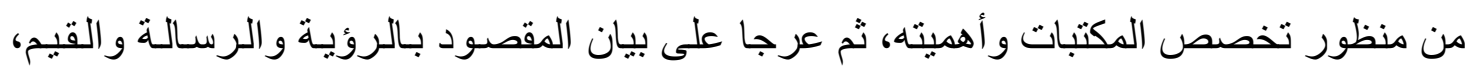

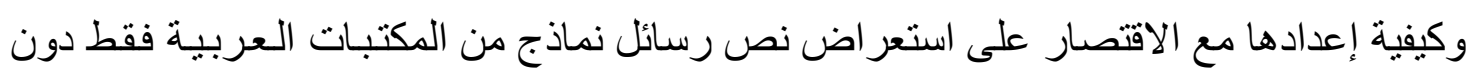

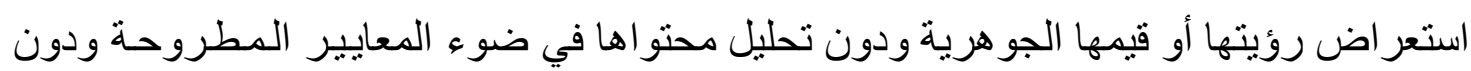

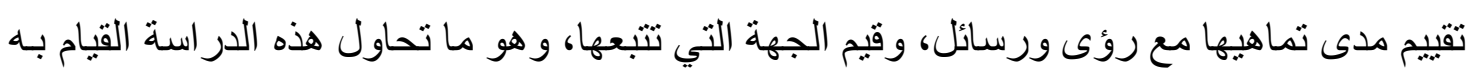
باستخدام منهجية مختلفة. أما بالنسبة للإنتاج الفكري الأجنبي: فقد كان هناك عدد من البحوث و الدر اسات تتاول معظمها

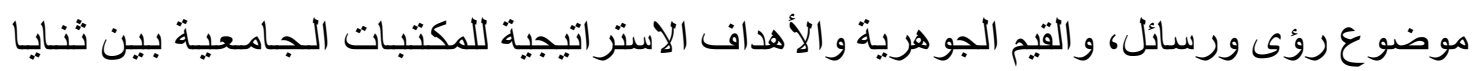

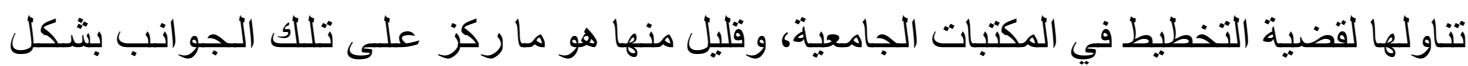

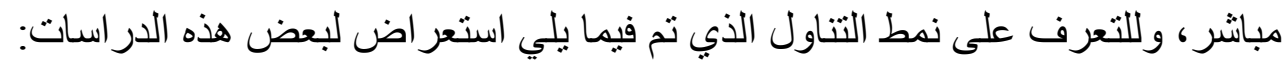

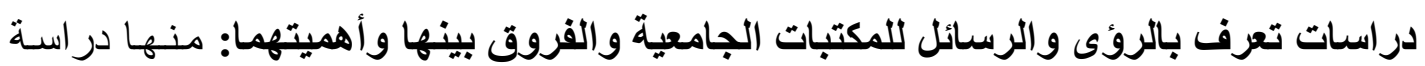

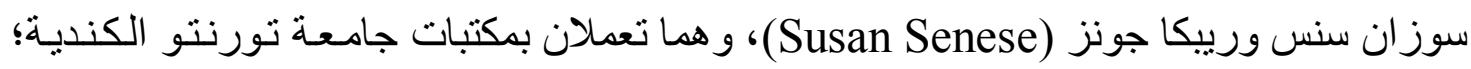

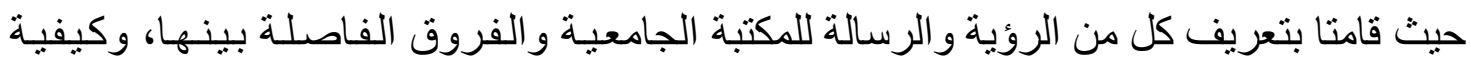
صياغة كل منهما من خلال عرض تجربتهما في التخطيط لمكتبات الجامعة لأكثر من عـام كامل كما أشتارتا إلى أن صياغة الرؤية تتأثز مباشرة بكافة ما تقوم به مكتبات الجامعة من عمليات ومـا

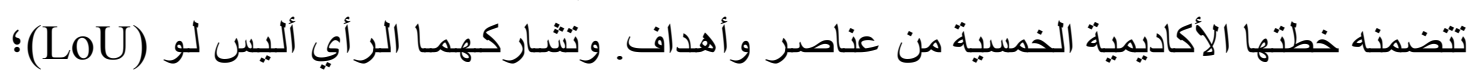

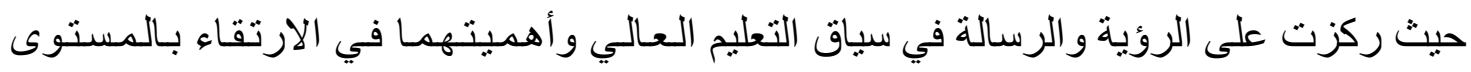
التعليمي لأية مؤسسة تعليمية أكاديمية، كما تناولت علاقة لتهية التخطيط الاستر اتيجي بالرؤية و الرسالة وضرورة إستمر اريته. أمـا نيل كوكيميولر (Kokemuller)؛ فقد ركز على على أهميـة الرؤيـة

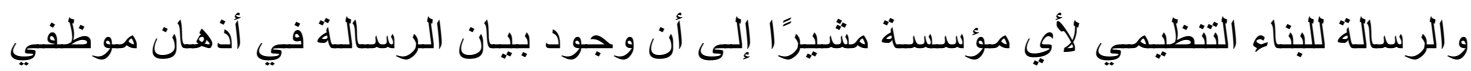

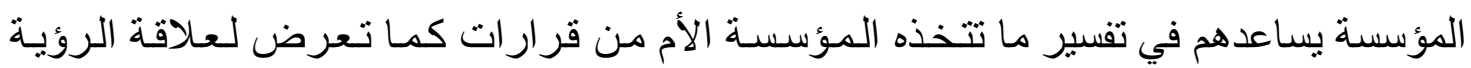

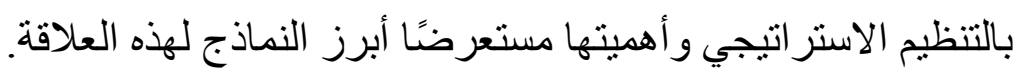

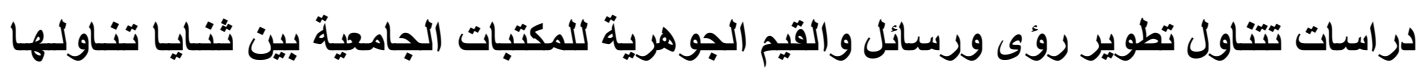

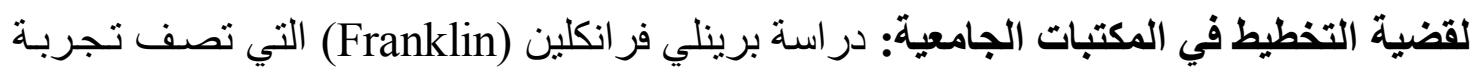
مكتبات جامعة كونيتيكيت UConn Libraries في وضع خطتها الاستر اتيجية في سباق خطة

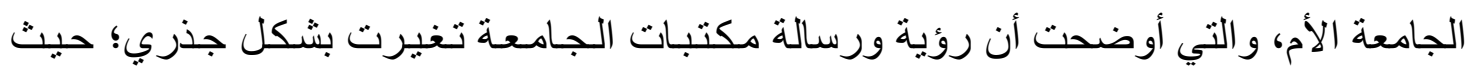
أصبحت تركز بشكل أكبر على الأفر اد، و الكفاءات، ونظم الجامعة، و الثقافة و البيئة المحبطة ورئة بها.

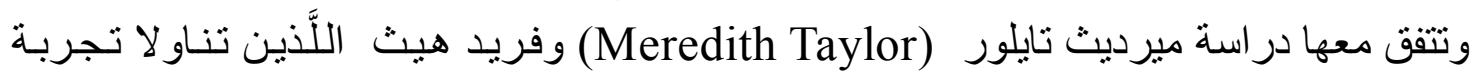
مكتبات جامعة تكساس بأوستين University of Texas at Austin في إعادة تقييم خطنهـا 
الاستر اتيجية و التي ركزت رؤية رسالة جامعتهما على خدمة أفر اد المجتمع وخاصة خدمة العملية التعليمية والتدريسية، وتحقيق التميز في البحث العلمي وتيسير اكتشاف المعلومات و المعرفة. أمسا در اسة جيف ويليامز وتامي ديري وبر اين سكوتلاندر (Jeff Williams) فقد وصفت وتئ الخطوات

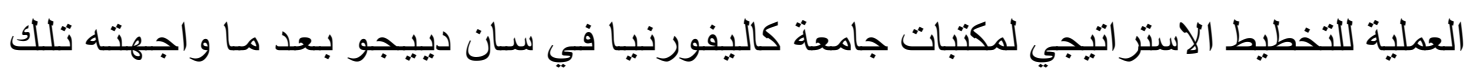
المكتبات من تخفيض في ميز انيتها و أصبح تركيز ها على المصادر الإلكترونية أكثر من المصسادر

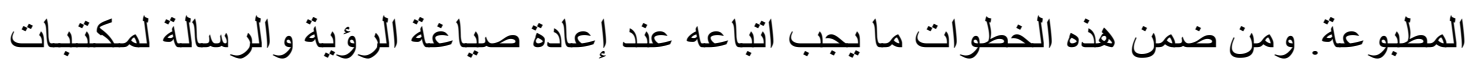

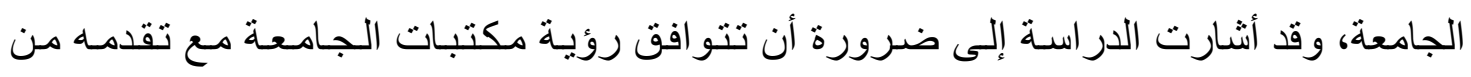

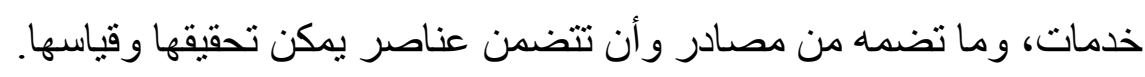
دراسات تتناول معايير صياغة الرؤى والرسـائل للمكتبـات الجـامعية: - Assosication)

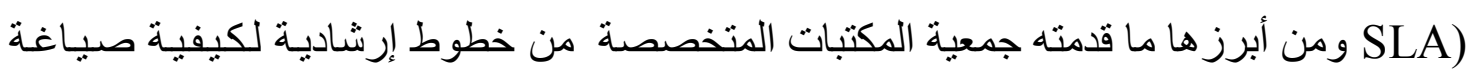

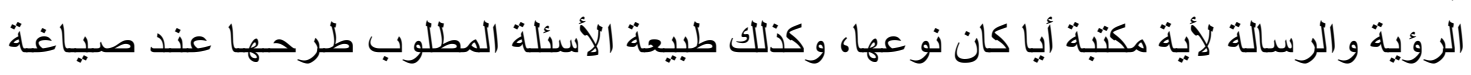

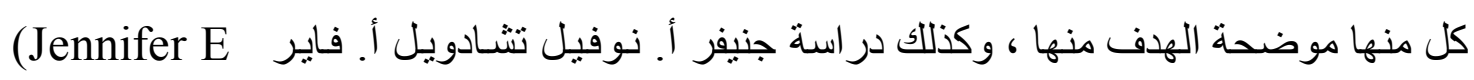
Nutefall)

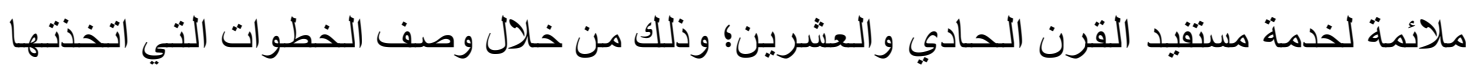

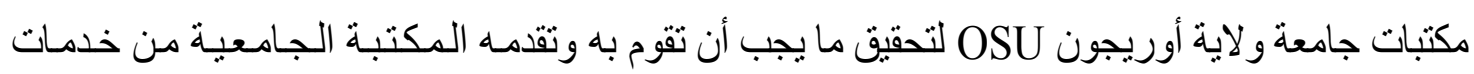

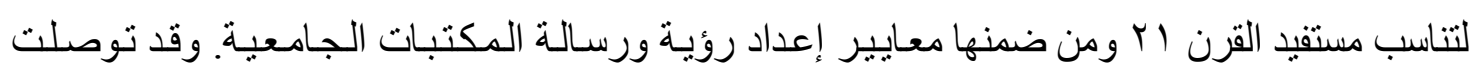

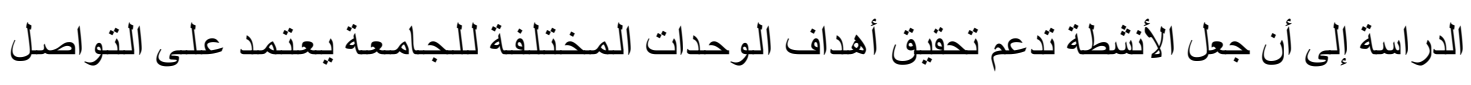

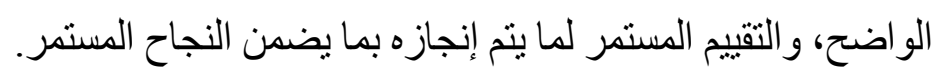

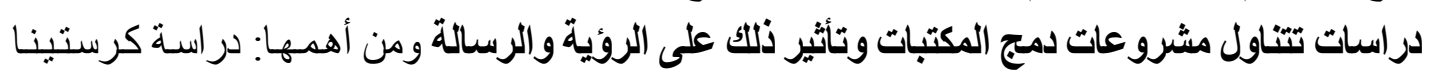

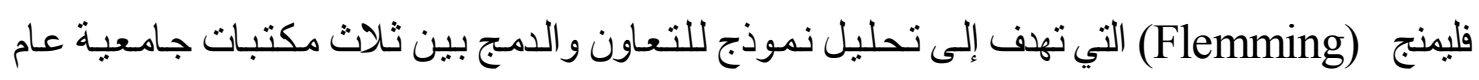

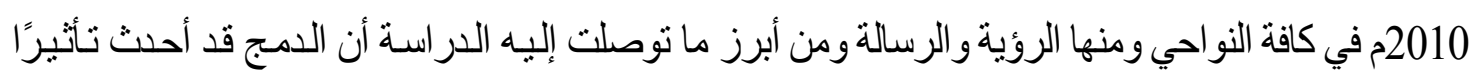

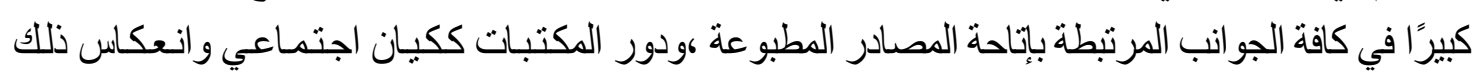
على رؤية ورسالة تلك المكتبات معًا. بناء على ما سبق يمكن القول إن هذه الدراسة جاءت لتحاول أن تسد فر اغًا في البناء المعرفي للتخصص على صعيد جهود التخطيط الاستر اتيجي، و استكثاف مدى التزام المعايير جودة الأداء

و مؤشر ات القياس فيا يتعلق بوضع وصياغة رؤى ورسائل و القيم الجو هرية للمكتبات الجامعية.

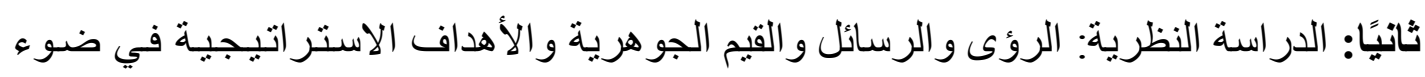

التخطيط الاستر اتيجي بالمكتبات الجامعية: r/ 1 التخطيط الاستراتيجي في المكتبات الجامعية:

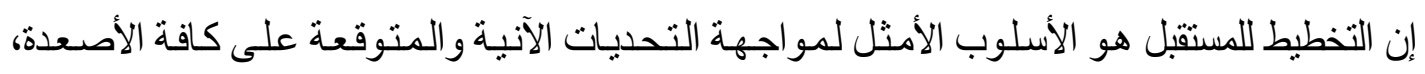


و التخطيط الاستر اتيجي تحديدًا يعد في جو هره جهذًا منظدًا بسـاعد في اتخاذ القرارات المصبريـة، وبـالنسبة

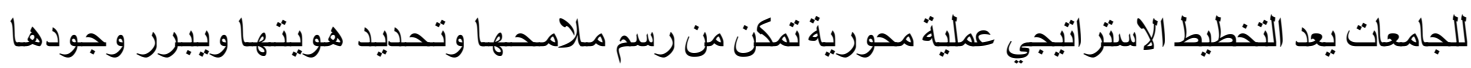

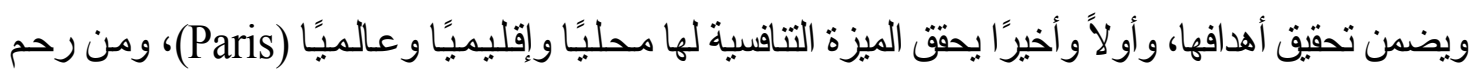

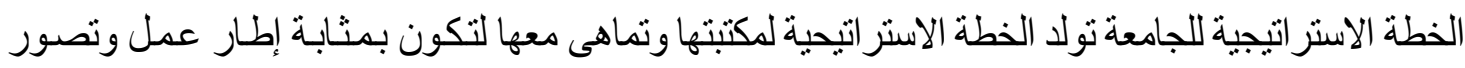
لنوع وطبيعة الإسهام الذي يمكن أن تقوم به المكتبة في بناء وتشكيل مستقبل الجامعة، وذلك من خن خلال تحليل

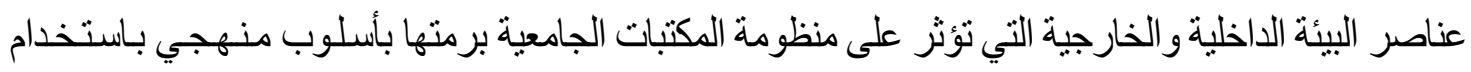

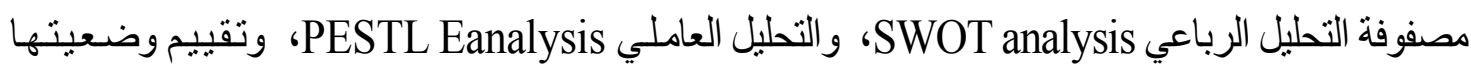

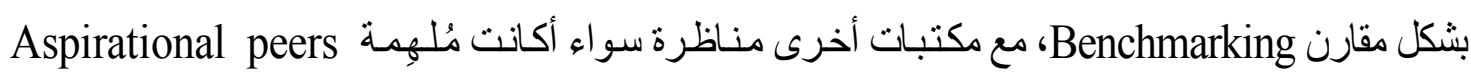
تمنل الطموح البعبد كمكنبات الجامعات؛ التي تحتل المر اتب المتقدمة في التصنيف العالمي، أو قابلـة للمقارنة Comparable peers التمثل بها وتكر ار تجربتها، كذلك في إطار إعداد هذه الخطة الاستر اتيجية يتم التعرف على طبيعة الاحتياجـات المعلو ماتية لمجتمع المستقيدات من خلال إجر اء مسوحات تمكن من استكثناف وتحليل سماتهم و اهتماماتهم.

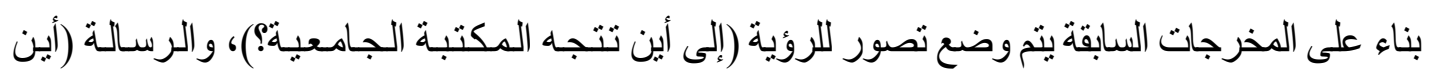
تقف المكتبة الجامعية؟)، والقيم الجوهرية (ما الإطار الأخلاقي و القيمي الذي يحكم عمل المكتبـة الجامعيبة؟) و الأهداف الاستراتيجية للمكتبة الجامعية التي تسعى لتحققها (كيف يمكن للمكتبـة الجامعية أن تصل إلى مـا

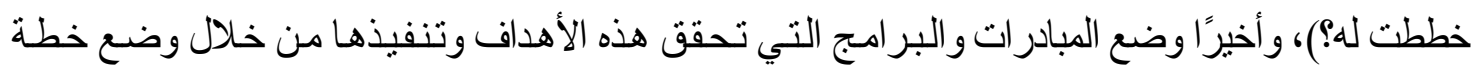

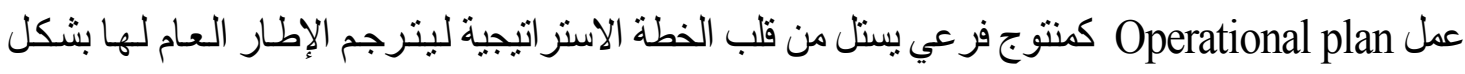
عملي. وخطة العمل هذه أو كما يطلق عليها أحيانًا الخطة تشغيلية المشار إليها هذه تعد امتدادًا وتتفيذًا للخطة

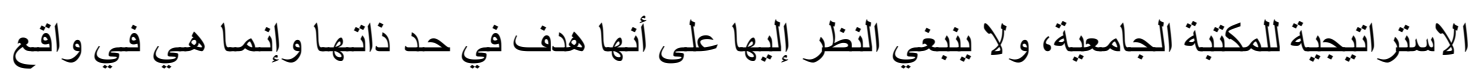

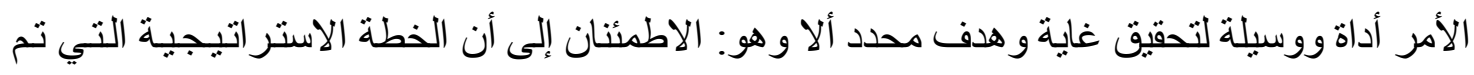

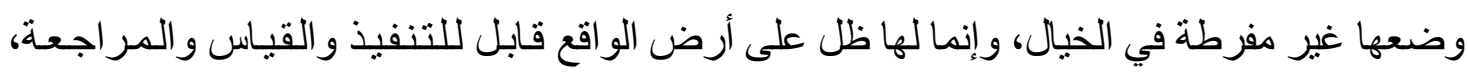

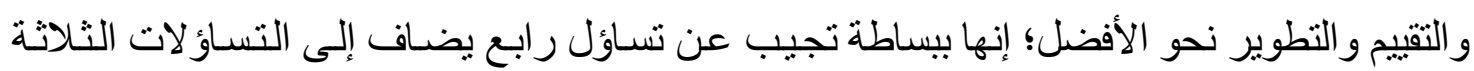
المشار إليها في بداية هذه الفقرة وهو (كيف يمكن قياس الأداء في المكتبة الجامعية بشكل موضو عي؟) الجئ.

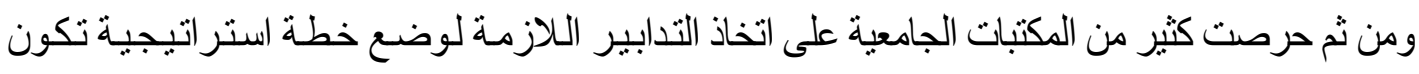

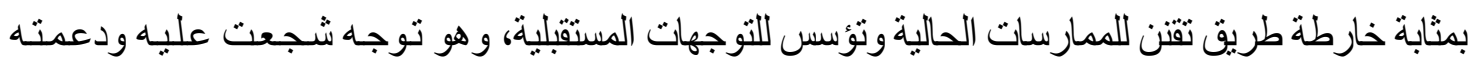

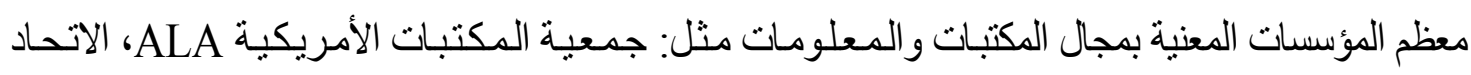

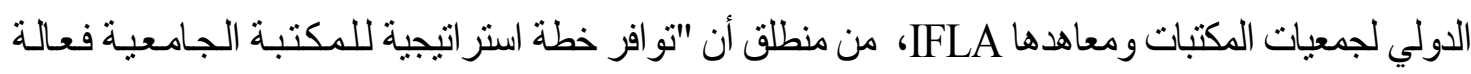

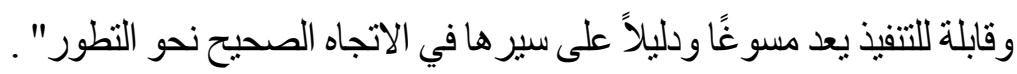

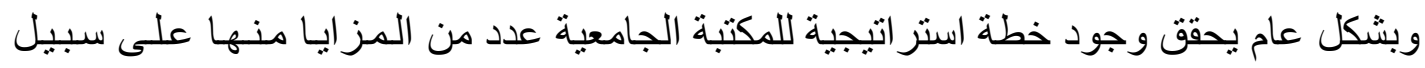




$$
\text { المثال لا الحصر ، ما يأتي ما يأتي (أحمد، ص با ـ ـ } 0 \text { (1). }
$$

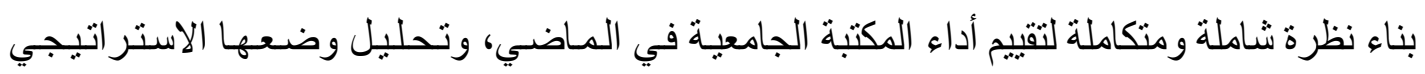
في الحاضر، ثم تكوين نظرة شاملة إستشر افية من أجل المستقبل.

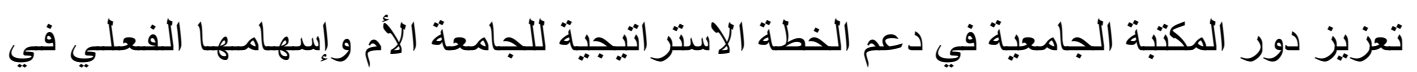
حصولها على الاعتماد الأكاديمي. الوقوف على مو اطن الضعف ومصادر التهحيد التي تعيق نمو المكتبة الجامعية وتطور ها، جنبًا إلى الى

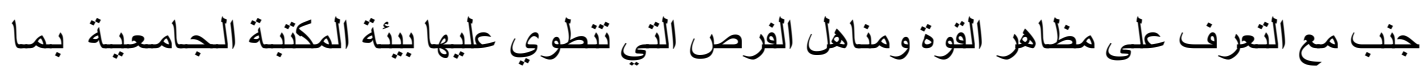
يمكن استثماره في الارتقاء بمستوى الأداء.

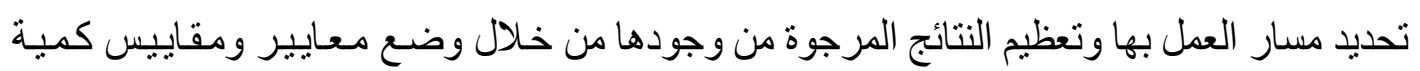
للتأكد من دقة وجودة الأداء، وتحقق الأهداف عبر الزئن الزمن. تحقيق الاستثمار الأمثل للمو ارد البشرية والمادية و المالية المتاحة للمكتبة الجـامعيـة، مـع فتح المجـال

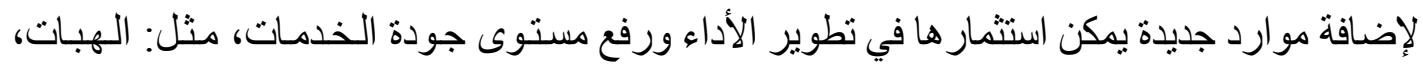

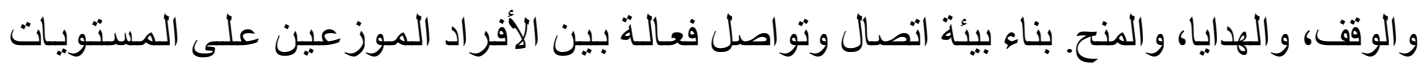
الإدارية المختلفة في الهيكل التنظيمي للمكتبة الجامعية.

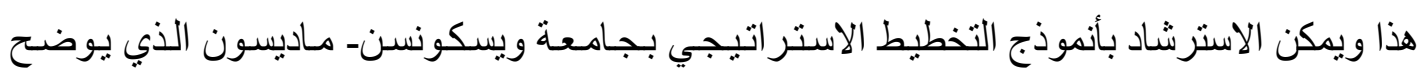

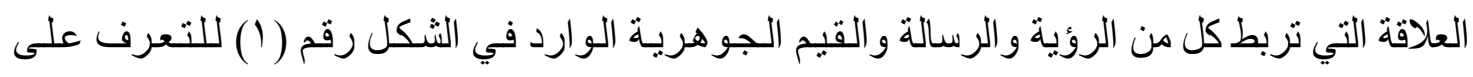

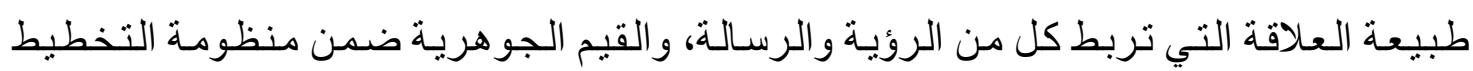
الاستر اتيجي (Paris P3):

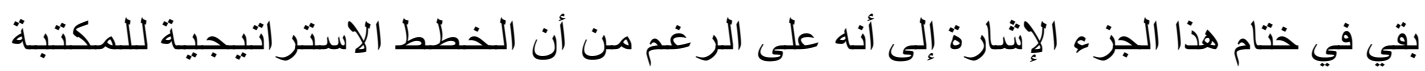

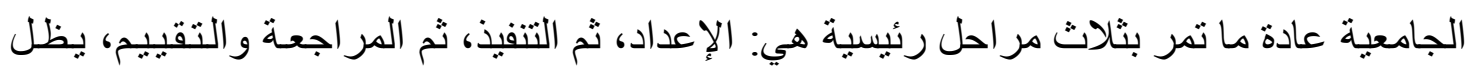

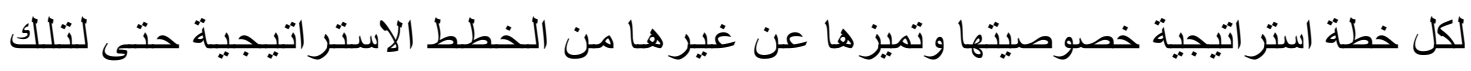

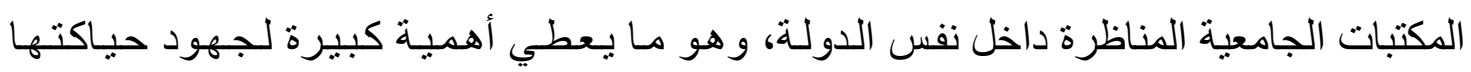

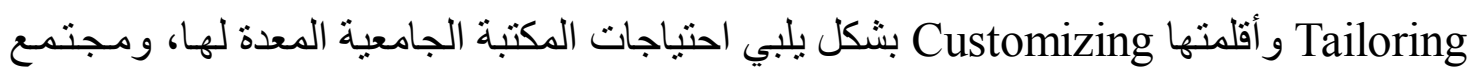

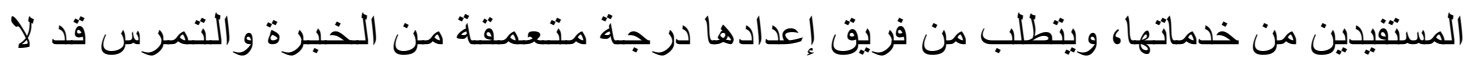

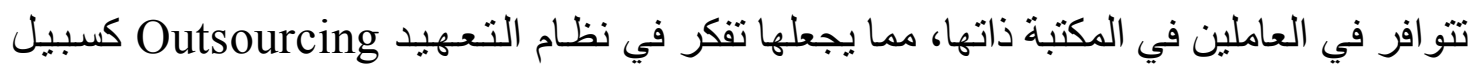
لتحقيق ذللك بكفاية وفعالية.

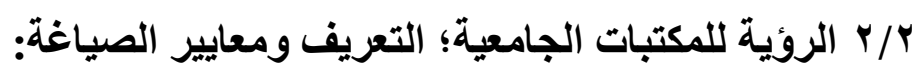
r/Y تضمن قاموس وبستر الإلكتروني معنى لكلمة الرؤيسة Vision يتسـق مـع السياق الذي نحن بصدده هنا، وهو أنها عبارة عن "اعتقاد أو مفهوم أو شيء يتشكل من خلال التخيل" Merriam) 
-Webster, Vision)

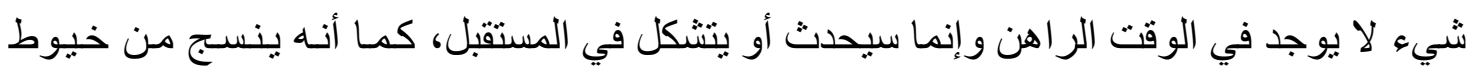
خيال صاحب الرؤية (المكتبة الجامعية).

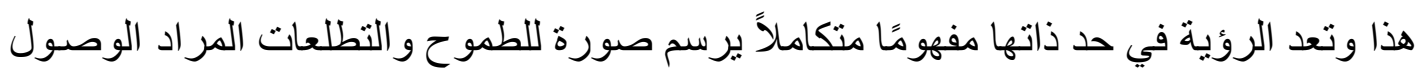

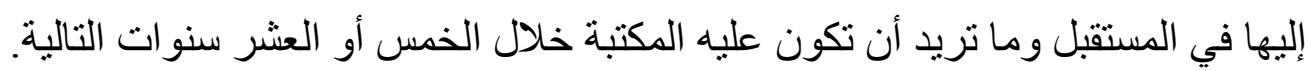

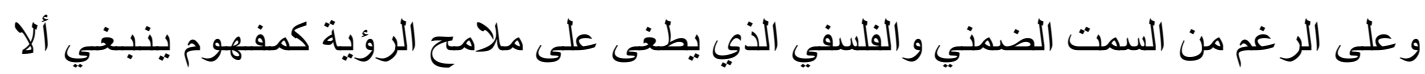
تختزل في وتتحصر في كلمات مجردة منمقة مفرطة في الخيال بعيدة كل البعد عن الو الو اقع و إمكانية

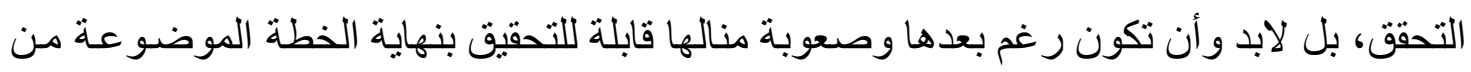

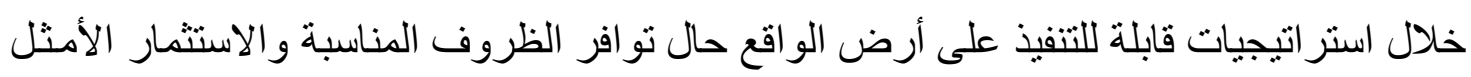
للمو ارد المتاحة.

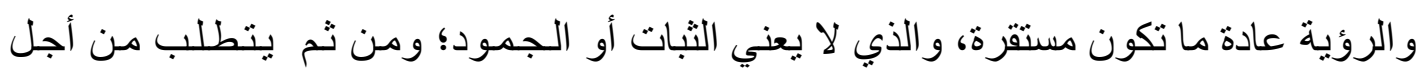

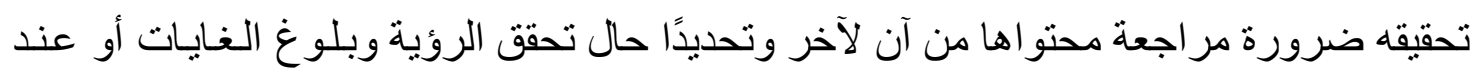
حدوث ما ينبئ بالحيد عنها.

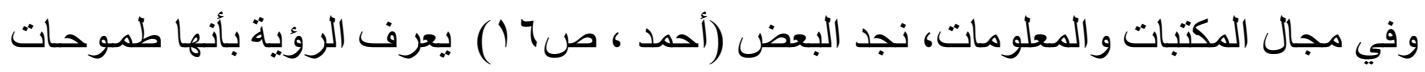

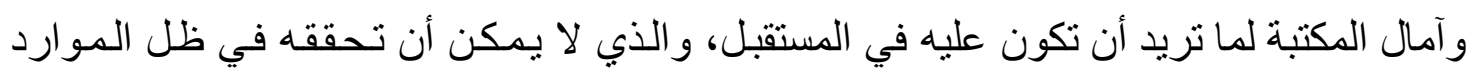
المتاحة حاليًاً لها.

ومن جانبها تعرف جمعية المكتبات المتخصصة SLA الروئية بأنها (Assosication - SLA)

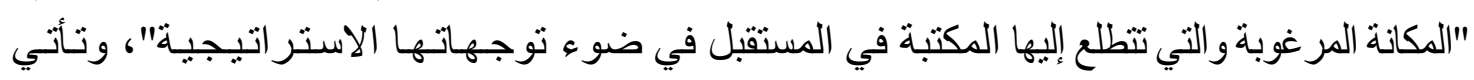
صياغة الرؤية من خلال الإجابة عن الأسئلة الآتية التي يتعين على المئي المكتبة الجامعية الإجابة عنها:

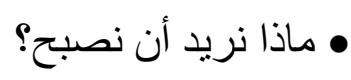

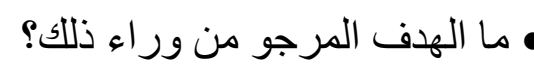

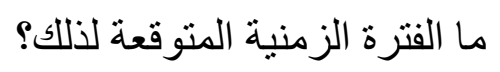
r r/r/r

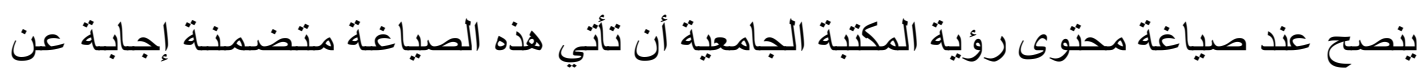
التساؤل الأساسي الآتي كحد أدنى:

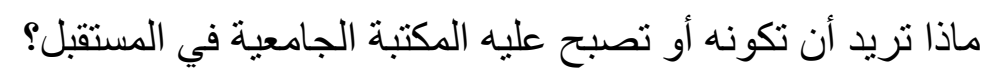

What does the University Library want to be or to become in the future? مع إمكانية أن يضاف إلى هذه الإجابة إجابات عن واحد أو أكثر من التساؤلات الأخرى الآتية

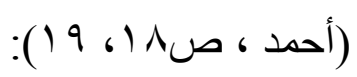

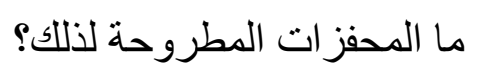




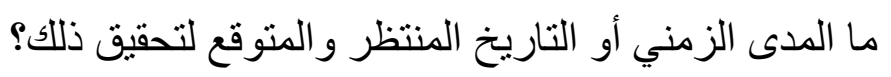

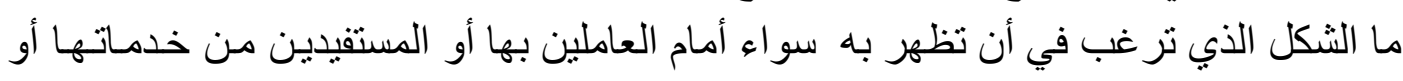

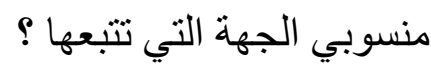

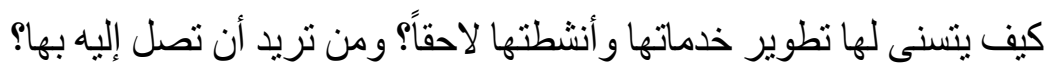

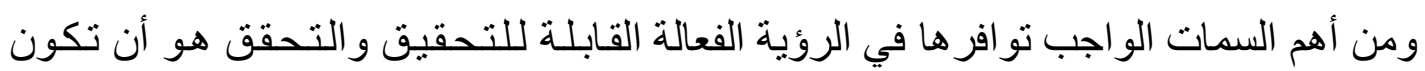

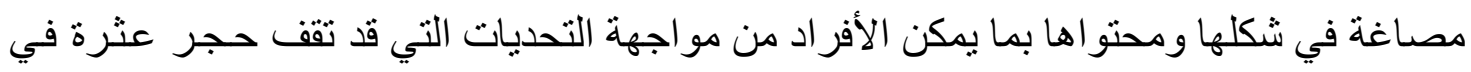

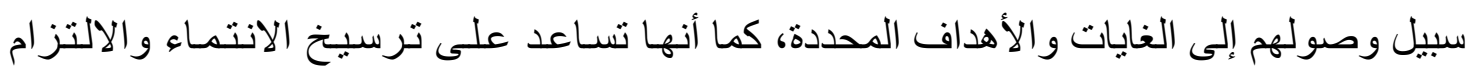

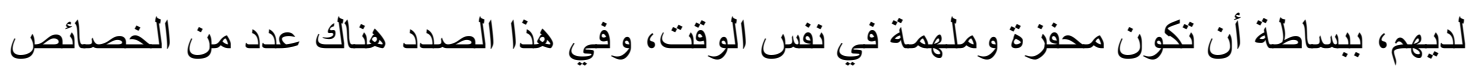

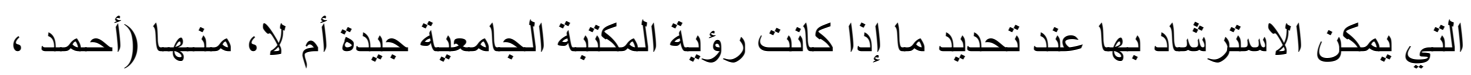

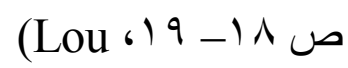

أن تكون قد وضعت بمشاركة جميع أصحاب العلاقة والمصلحة المعنيين بأمر المكتبة الجامعية و المتعاملين معها.

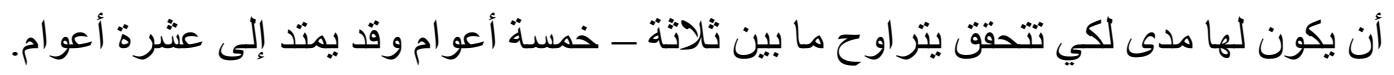

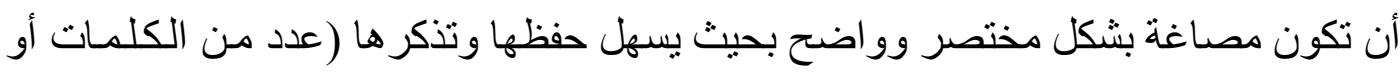

أن تصف مرحلة أو حالة محددة (إيجابية بالطبح) ستكون عليها المكتبة الجامعية في المستقبل.

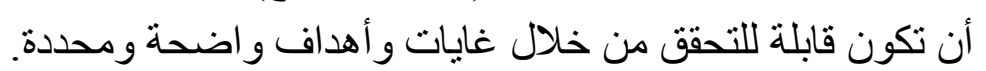

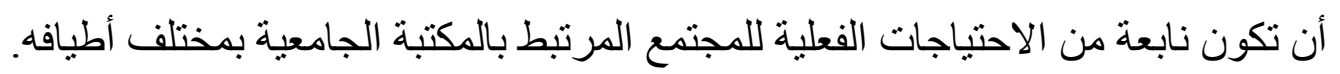

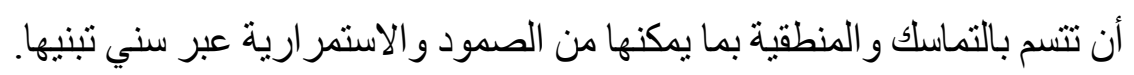

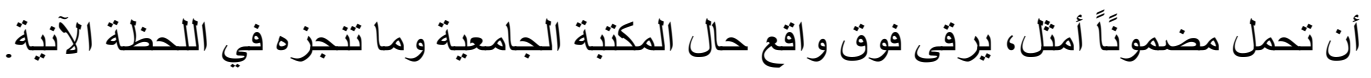

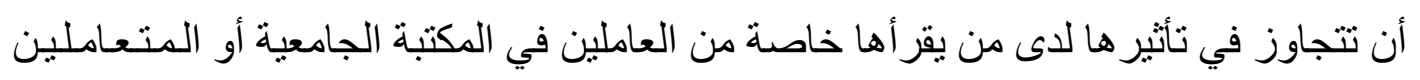

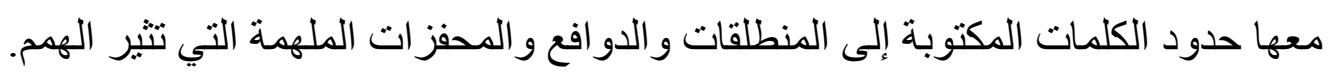

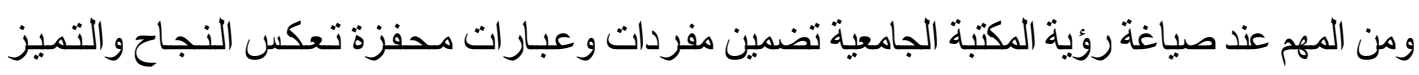

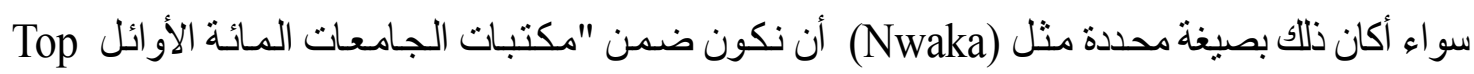

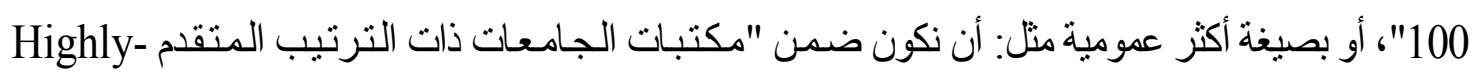

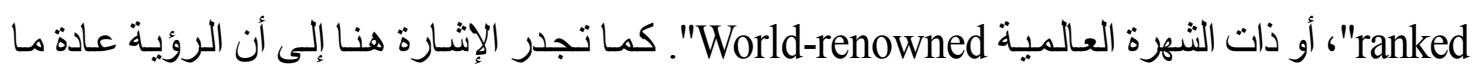

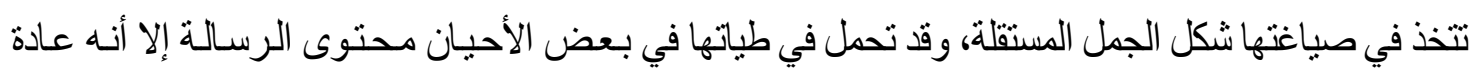
يفضل الفصل بينهما لاختلاف الهنف من كل منهما وطبيعة الصياغة (Quain).

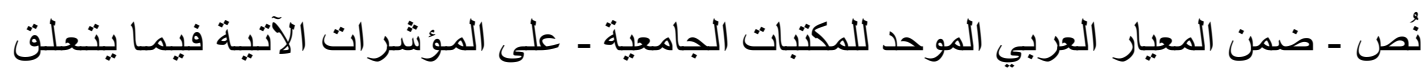

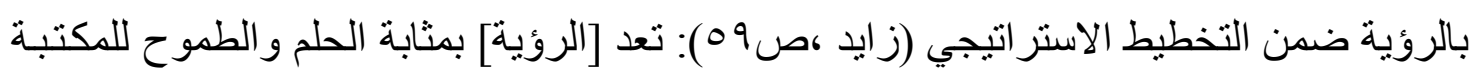


الجامعية التي لا يمكن تحقيقها في ظل الإمكانيات الحالية و إن كان من الممكن الوصول إليها في الأجل الطويل، وهي ينبغي أن تكون: • مسجلة ومعتمدة. • معلنة في المباني. • معلنة على موقع المكتبة على الإنترنت.

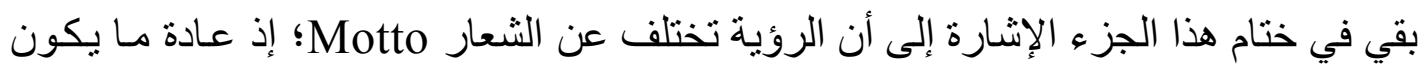

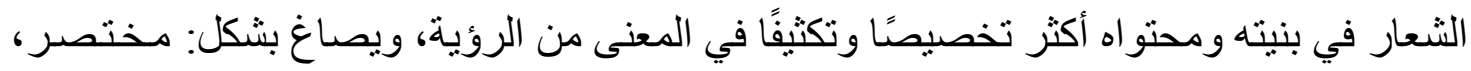

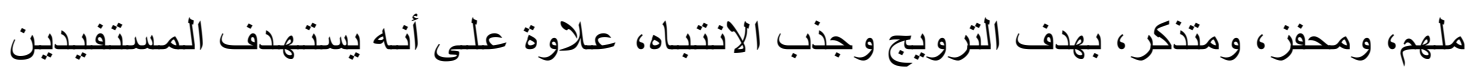

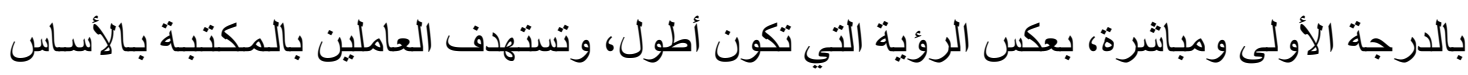

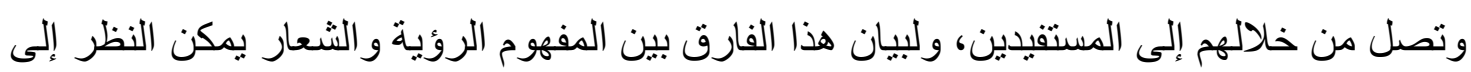

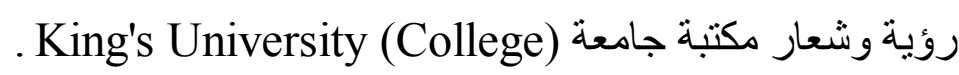

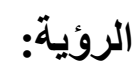

To support scholarship, intellectual growth and critical inquiry, and to promote a continuing love of learning in a welcoming space where people choose to gather.

الثعار:

"Experience the Heart of King's"

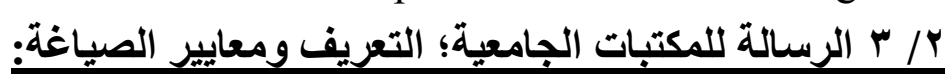

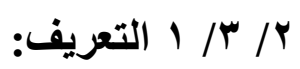

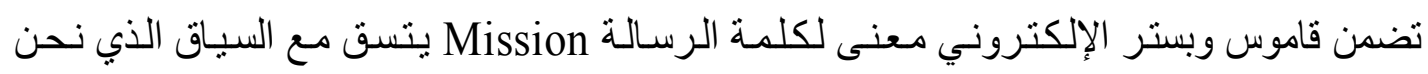

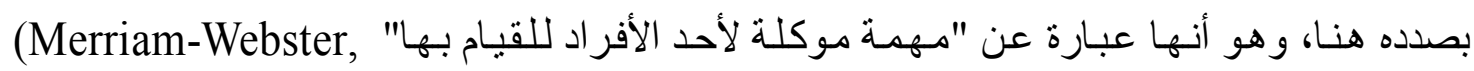

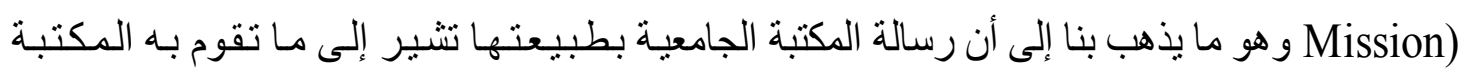

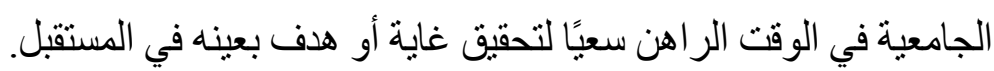

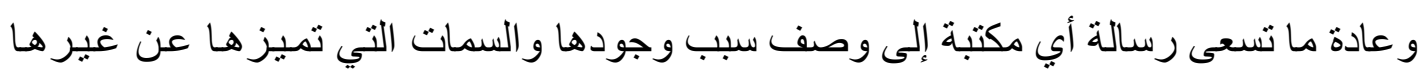

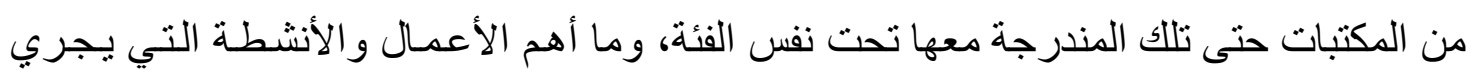

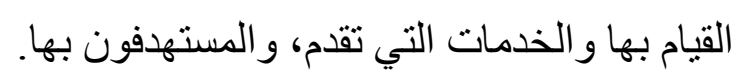

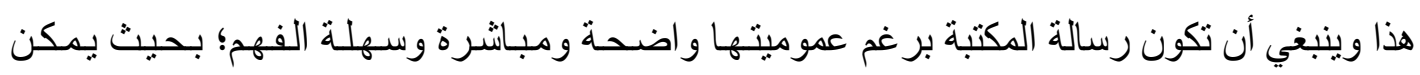

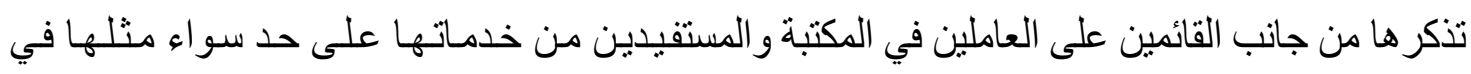

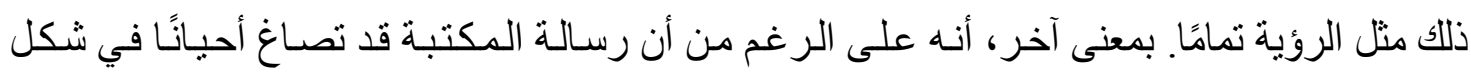

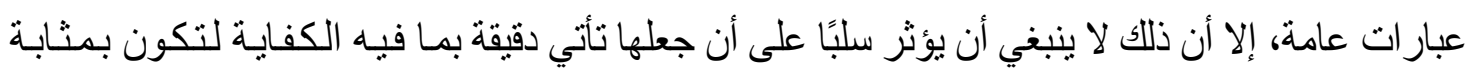


بوصلة لاتجاه السير، ودليل للتخطيط واتخاذ القرار على جميع المستويات الإدارية. وتعرف جمعية المكتبات المتخصصة Assosication-SLA) SLA) نص (أو بيان) الرسـالة Mission statement بأنه بيان يحدد الهدف الرئيسي للمكتبة، ويصف بإيجاز مبرر وجودهـا،

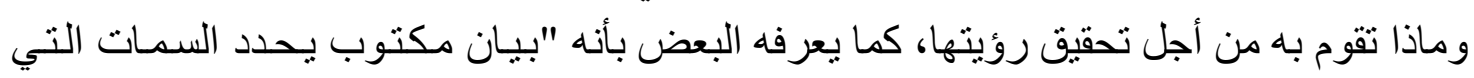

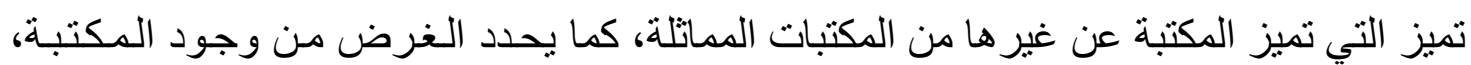
ويضع الملامح الرئيسية للخدمات و الأنشطة التي تقدمها". و عادة ما تأتي صياغة رسالة المكتبة الجامعية من خلال إجابة القائمين على أمر ها عن الأسئلة

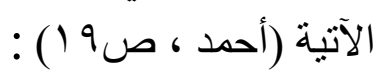

$$
\begin{aligned}
& \text { من نحن؟ الآه } \\
& \text { ماذا نريد؟ هن نهن }
\end{aligned}
$$

إلى من نوجه خدماتتا ومجهوداتنا؟

لماذا نفعل ذلك؟ وما الهدف من تلك الجهو د؟ وكيف تنت بكفاية وفعالية؟

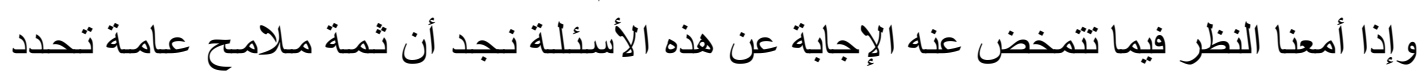
طبيعة رسالة المكتبة الجامعية يمكن تلخيصها على النحو الآتي: م إنها تبنى على فحوى الرؤية وتسعى لتحقيقها وتؤدي لتحققها.

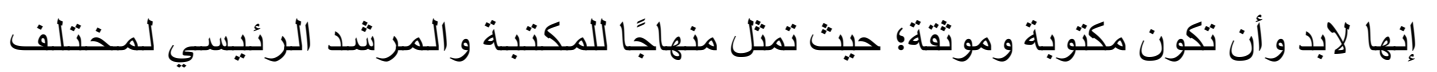

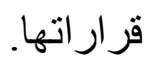
إنها تغطي فترة طويلة نسبيًا ولكنهـا لا بمكن أن تتجـاوز مدة تحقق الرؤيسة بأي حال من

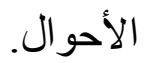
إنها تحدد بوضوح كينونة المكتبة، وطبيعة الأنشطة التي تقوم بها المكتبـة الجـامعيـة، والخدمات التي تثوفر على تقديمها. إنها تحدد فئات المستفيدين المستهدفين بخدماتها.

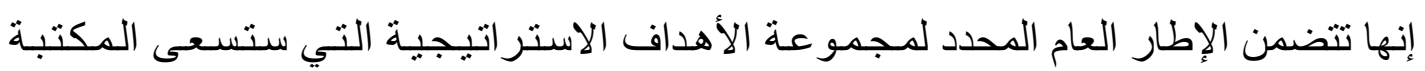
الجامعية للوصول إليها. إنها تحدد الكيفية التي تؤدى بها الأنشطة أو الخدمات، ومستوى الجودة المطلوب.

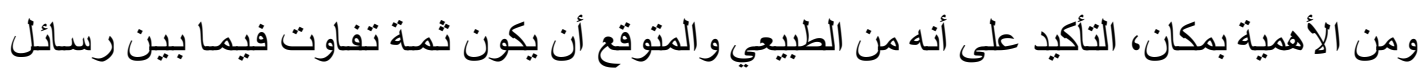

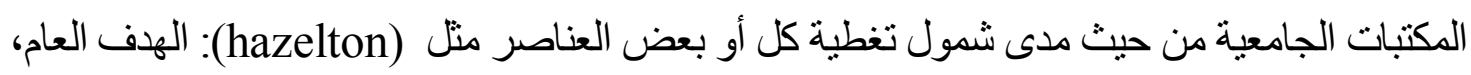

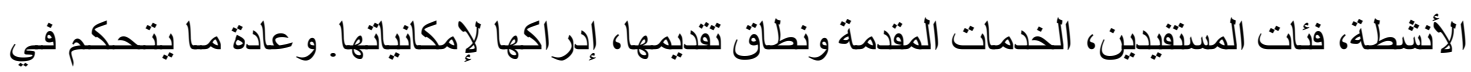

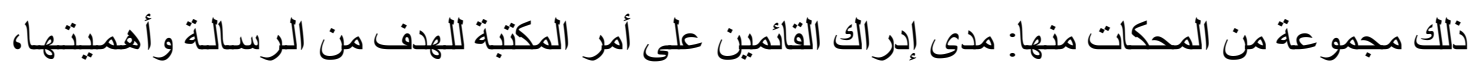


مدى الإلمام بمعايير صياغتها، وطبيعة وخلفيات الأفر اد المشاركين في إعدادها (أفر اد من الإدارة العليا بالجامعة و المكتبة، ممثلين عن الإدار ات والأقسام المختلفة، ممثلين لفئات المستفيدين المستهـين إعدفين بمختلف أطيافهم). r/r/r r r r معايير الصياغة:

\section{ملاحق الاراسة}

الملحق رقم ( (1): قائمة مر اجعة لتحليل وتقييم محتوى رؤى ورسـائل والقيم الجو هريـة لعينـة

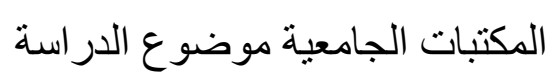
المحور الأول: البيانات التعريفية بالمكتبة الجامعية 1/1 اسم الجامعة التي تتبعها المكتبة الجامعية ب/ ا ـ الموقع الإلكتروني للمكتبة الجامعية. س/ ا ـ طبيعة تشكيل المكتبة الجامعية و الجامعات التابعة لها. المحور الثاني: معلومات حول رؤى ورسائل و القيم الجوهرية للمكتبة الجامعية T/T. هل الخطة الاستر اتيجية للجامعة متاحة على موقعها الإلكتروني الرسمي ( ) نعم (يتم الاطلاع عليها وتحليل محتو اهـا من حيث الرؤيـة و الرسـالة والقيم

$$
\begin{aligned}
& \text { الجو هرية). } \\
& \text {. }
\end{aligned}
$$

r/Y ب. هل الخطة الاستر اتيجية للمكتبة الجامعية متاحة على موقعها الإلكتروني الرسمي ( ) نعم (يتم الاطلاع عليها وتحليل محتو اهـا من حيث الرؤيسة والرسـالـة والقيم

$$
\text { (الجوهرية). }
$$

r / ب. هل يوجد للمكتبة الجامعية سو اء في خطة الاستر اتيجية أو على موقعها الإلكتروني ما يأتي: 
الفهرست سع 1، ع rه ( يناير 17 • (Y) رؤى ورسائل والقيم الجوهرية للمكتبات الجامعية

$$
\begin{aligned}
& \text { ( ) الرؤية والقيم الجوهرية } \\
& \text { ( ) ( ) (الرسالة و القيم الجوهرية الجية } \\
& \text { ( ) ( ) (الروية و الرسالة و القيم الجو هرية }
\end{aligned}
$$

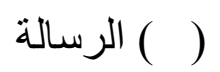

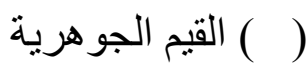

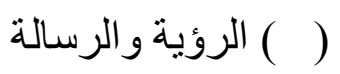

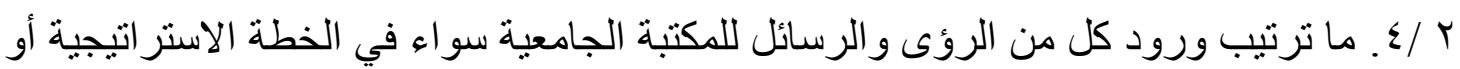

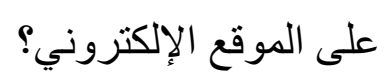

r / / / كم عدد الكلمات التي تتكون منها كل من رؤى ورسائل و القيم الجو هرية للمكتبة الجامعية؟

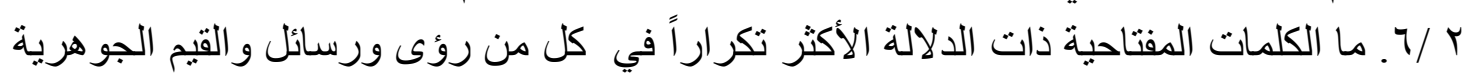

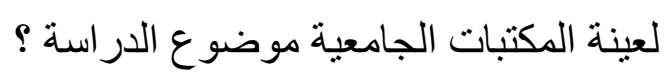

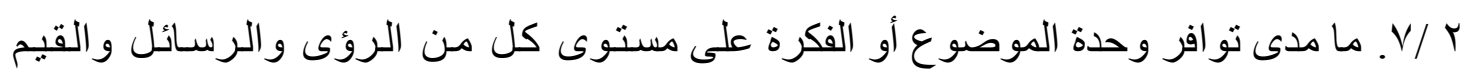

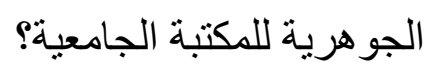

\begin{tabular}{|c|c|c|c|c|c|c|c|c|}
\hline للجكورية الجية & الجامعتة & الجمامية & اللإكتروني & للجوالجمرية & روريالة & العالمي & اسم الجامعة & الدولة \\
\hline & $\checkmark$ & - & $\checkmark$ & - & - & $\begin{array}{c}1 \\
\mathrm{QS} / 2\end{array}$ & $\begin{array}{c}\text { Harvard } \\
\text { University }\end{array}$ & الألايات المتحدة \\
\hline - & - & - & $\underline{\checkmark}$ & - & - & $\begin{array}{c}r \\
\mathrm{QS} / 7\end{array}$ & $\begin{array}{l}\text { Stanford } \\
\text { University }\end{array}$ & الألوايات المتحدة \\
\hline$\checkmark$ & $\checkmark$ & $\checkmark$ & $\begin{array}{l}- \\
\checkmark\end{array}$ & $\checkmark$ & $\checkmark$ & $\begin{array}{c}r \\
\mathrm{QS} / 25\end{array}$ & $\begin{array}{c}\text { University of } \\
\text { California, } \\
\text { Berkeley }\end{array}$ & الو لايات المتحدة \\
\hline & $\checkmark$ & $\checkmark$ & $\underline{v}$ & - & $\checkmark$ & $\begin{array}{c}\varepsilon \\
\mathrm{QS} / 1\end{array}$ & $\begin{array}{c}\frac{\text { Massachusetts }}{\underline{\text { Institute of }}} \\
\frac{\text { Technology }}{\text { (MIT) }}\end{array}$ & الألوريكية المتحدة \\
\hline
\end{tabular}

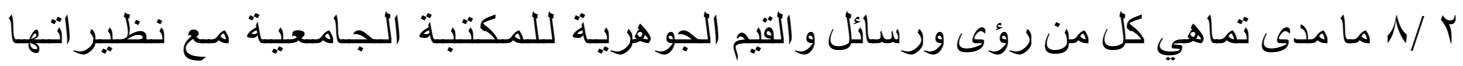

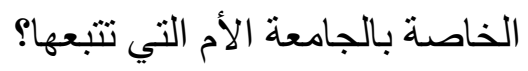

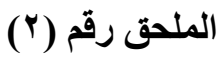

جدول يوضح مدى تو افر الرؤى والرسائل والقيم الجوهرية

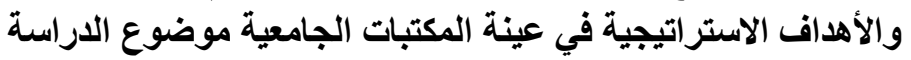




\begin{tabular}{|c|c|c|c|c|c|c|c|c|}
\hline- & $\checkmark$ & $\checkmark$ & $\checkmark$ & - & $\checkmark$ & $\begin{array}{c}0 \\
\mathrm{QS} / 3\end{array}$ & $\begin{array}{l}\text { University of } \\
\text { Cambridge }\end{array}$ & المملكة المتحدة \\
\hline- & - & - & $\underline{\checkmark}$ & - & - & $\begin{array}{c} \\
\text { QS/10 }\end{array}$ & $\begin{array}{c}\text { California } \\
\text { Institute of } \\
\text { Technology }\end{array}$ & الألايات المتحدية \\
\hline- & - & - & $\checkmark$ & - & - & $\begin{array}{c}\mathrm{V} \\
\mathrm{QS} / 10\end{array}$ & $\begin{array}{l}\text { Princeton } \\
\text { University }\end{array}$ & الألايات المتحدة \\
\hline$\checkmark$ & $\checkmark$ & $\checkmark$ & $\checkmark$ & - & $\checkmark$ & $\begin{array}{c}\wedge \\
\text { QS/14 }\end{array}$ & $\begin{array}{l}\text { Columbia } \\
\text { University }\end{array}$ & الألايات المتحدة \\
\hline$\checkmark$ & $\checkmark$ & $\checkmark$ & $\checkmark$ & - & $\checkmark$ & $\begin{array}{c}9 \\
\text { QS/9 }\end{array}$ & $\begin{array}{c}\text { University of } \\
\text { Chicago }\end{array}$ & الوالايات المتحدة \\
\hline- & $\checkmark$ & $\checkmark$ & $\checkmark$ & - & $\checkmark$ & $\begin{array}{c}1 . \\
\text { QS/6 }\end{array}$ & $\begin{array}{c}\text { University of } \\
\text { Oxford }\end{array}$ & الألوريكية المتحدة \\
\hline- & $\checkmark$ & $\checkmark$ & $\checkmark$ & $\checkmark$ & $\checkmark$ & $\begin{array}{c}11 \\
\text { QS/8 }\end{array}$ & Yale University & الألايات المتحدية \\
\hline$\checkmark$ & $\checkmark$ & $\checkmark$ & $\checkmark$ & - & $\checkmark$ & $\begin{array}{c}\mathrm{IT} \\
\mathrm{QS} / 40\end{array}$ & $\begin{array}{c}\text { University of } \\
\text { California, Los } \\
\text { Angeles }\end{array}$ & الو لأيات المتحدة \\
\hline- & $\checkmark$ & $\checkmark$ & $\checkmark$ & $\checkmark$ & $\checkmark$ & $\begin{array}{c}1 \pi \\
\text { QS/15 }\end{array}$ & $\begin{array}{c}\text { Cornell } \\
\text { University }\end{array}$ & الوالايات المتحدية \\
\hline$\checkmark$ & $\checkmark$ & $\checkmark$ & $\checkmark$ & $\checkmark$ & $\checkmark$ & $\begin{array}{c}1 \leq \\
Q S / 63\end{array}$ & $\begin{array}{c}\text { University of } \\
\text { California, San } \\
\text { Diego }\end{array}$ & الو لأيات المتحدة \\
\hline$\checkmark$ & $\checkmark$ & - & $\checkmark$ & - & - & $\begin{array}{c}10 \\
Q S / 13\end{array}$ & $\begin{array}{l}\text { University of } \\
\text { Pennsylvania }\end{array}$ & الوالايات المتحدة \\
\hline$\checkmark$ & $\checkmark$ & $\checkmark$ & $\checkmark$ & $\checkmark$ & $\checkmark$ & $\begin{array}{c}17 \\
\text { QS/63 }\end{array}$ & $\begin{array}{l}\text { University of } \\
\text { Washington }\end{array}$ & الألايات المتحدية \\
\hline- & - & - & $\checkmark$ & - & - & $\begin{array}{c}\mathrm{IV} \\
\mathrm{QS} / 16\end{array}$ & $\begin{array}{l}\text { The Johns } \\
\text { Hopkins } \\
\text { University }\end{array}$ & الو لأيات المتحدة \\
\hline- & - & $\checkmark$ & $\checkmark$ & - & $\checkmark$ & 11 & $\begin{array}{c}\underline{\text { University of }} \\
\frac{\text { California, San }}{\underline{\text { Francisco }}}\end{array}$ & الو لأيات المتحدة \\
\hline- & $\checkmark$ & $\checkmark$ & $\checkmark$ & - & $\checkmark$ & $\begin{array}{c}19 \\
Q S / 37\end{array}$ & $\begin{array}{l}\text { University of } \\
\text { Wisconsin - } \\
\text { Madison }\end{array}$ & 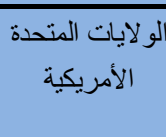 \\
\hline
\end{tabular}




\begin{tabular}{|c|c|c|c|c|c|c|c|c|}
\hline- & - & - & $\underline{\checkmark}$ & - & - & $\begin{array}{c}\mathrm{r} \cdot \\
\mathrm{QS} / 12\end{array}$ & $\begin{array}{c}\text { Swiss Federal } \\
\text { Institute of } \\
\text { Technology } \\
\text { Zurich } \\
\end{array}$ & سويسرا \\
\hline- & - & - & $\underline{\checkmark}$ & - & - & $\begin{array}{c}r \\
\mathrm{QS} / 32\end{array}$ & $\begin{array}{c}\text { The University of } \\
\text { Tokyo }\end{array}$ & اليابان \\
\hline$\checkmark$ & $\checkmark$ & $\checkmark$ & $\underline{\checkmark}$ & $\checkmark$ & $\checkmark$ & $\begin{array}{c}Y \\
Q S / 4\end{array}$ & $\begin{array}{c}\text { University } \\
\text { College London }\end{array}$ & المملكة المتحدة \\
\hline- & $\checkmark$ & - & $\underline{\checkmark}$ & - & - & $\begin{array}{c}r T \\
Q S / 22\end{array}$ & $\begin{array}{c}\text { University of } \\
\text { Michigan - Ann } \\
\text { Arbor }\end{array}$ & الو لأيات المتحدة \\
\hline- & $\checkmark$ & $\checkmark$ & $\underline{\checkmark}$ & $\checkmark$ & $\checkmark$ & $r \varepsilon$ & $\begin{array}{l}\text { The Imperial } \\
\text { College of } \\
\text { Science, } \\
\text { Technology and } \\
\text { Medicine }\end{array}$ & المملكة المتحدة \\
\hline$\checkmark$ & $\checkmark$ & $\checkmark$ & $\underline{\checkmark}$ & - & $\checkmark$ & $\begin{array}{c}\text { ro } \\
\text { QS/56 }\end{array}$ & $\begin{array}{l}\text { University of } \\
\text { Illinois at Urbana- } \\
\text { Champaign }\end{array}$ & الو لأيات المتحدية \\
\hline- & $\checkmark$ & $\checkmark$ & $\underline{\checkmark}$ & - & $\checkmark$ & $\begin{array}{c}r y \\
Q S / 35\end{array}$ & Kyoto University & اليابان \\
\hline- & $\checkmark$ & - & $\underline{\checkmark}$ & - & $\checkmark$ & $\begin{array}{c}Y V \\
Q S / 44\end{array}$ & $\begin{array}{l}\text { New York } \\
\text { University }\end{array}$ & 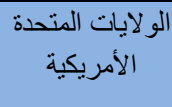 \\
\hline$\checkmark$ & $\checkmark$ & $\checkmark$ & $\underline{\checkmark}$ & - & $\checkmark$ & $\begin{array}{c}r \wedge \\
Q S / 17\end{array}$ & $\begin{array}{l}\text { University of } \\
\text { Toronto }\end{array}$ & كندا \\
\hline$\checkmark$ & $\checkmark$ & $\checkmark$ & $\underline{\checkmark}$ & $\checkmark$ & $\checkmark$ & $\begin{array}{c}r q \\
\mathrm{QS} / 10 \\
2\end{array}$ & $\begin{array}{c}\text { University of } \\
\text { Minnesota, Twin } \\
\text { Cities }\end{array}$ & الو لأيات المتحدة \\
\hline$\checkmark$ & $\checkmark$ & - & $\underline{\checkmark}$ & $\checkmark$ & $\checkmark$ & $\begin{array}{c}r \cdot \\
\mathrm{QS} / 29\end{array}$ & $\begin{array}{c}\text { Northwestern } \\
\text { University }\end{array}$ & $\begin{array}{c}\text { الألايات المتحدية } \\
\text { الأميكة }\end{array}$ \\
\hline$\checkmark$ & $\checkmark$ & $\checkmark$ & $\checkmark$ & - & $\checkmark$ & $\begin{array}{c}\mu \\
\mathrm{QS} / 23\end{array}$ & Duke University & الو لأيات المتحدة \\
\hline- & $\checkmark$ & $\checkmark$ & $\underline{\checkmark}$ & - & $\checkmark$ & $\begin{array}{c}\text { rY } \\
\text { QS/86 }\end{array}$ & $\begin{array}{c}\text { Washington } \\
\text { University in St. } \\
\text { Louis } \\
\end{array}$ & الو لأيات المتحدة \\
\hline- & $\checkmark$ & $\checkmark$ & $\underline{\checkmark}$ & - & $\checkmark$ & $\begin{array}{c}r \mathrm{r} \\
\mathrm{QS} / 16 \\
0 \\
\end{array}$ & $\begin{array}{c}\text { University of } \\
\text { Colorado at } \\
\text { Boulder } \\
\end{array}$ & الو لأيات المتحدة \\
\hline- & - & - & $\checkmark$ & - & - & $r \varepsilon$ & $\begin{array}{l}\text { Rockefeller } \\
\text { University }\end{array}$ & الو لأيات المتحدة \\
\hline
\end{tabular}




\begin{tabular}{|c|c|c|c|c|c|c|c|c|}
\hline- & - & - & $\checkmark$ & - & - & $\begin{array}{c}\text { ro } \\
\text { QS/13 } \\
0\end{array}$ & $\begin{array}{c}\text { University of } \\
\text { California, Santa } \\
\text { Barbara }\end{array}$ & الو لايات المتحدة \\
\hline- & - & - & $\checkmark$ & - & - & $\begin{array}{c}\text { rq } \\
\text { QS/71 }\end{array}$ & $\begin{array}{l}\text { The University of } \\
\text { Texas at Austin }\end{array}$ & الو لأمريكية المتحدة \\
\hline- & - & - & $\checkmark$ & - & - & $\begin{array}{c}r V \\
Q S / 11 \\
2\end{array}$ & $\begin{array}{c}\text { Pierre and Marie } \\
\text { Curie University - } \\
\text { Paris } 6\end{array}$ & فرنسا \\
\hline- & $\checkmark$ & - & $\checkmark$ & - & $\checkmark$ & $\begin{array}{c}r \wedge \\
Q S / 11 \\
6\end{array}$ & $\begin{array}{l}\text { University of } \\
\text { Maryland, } \\
\text { College Park }\end{array}$ & الو لأيات المتحديكة \\
\hline- & $\checkmark$ & - & $\checkmark$ & - & $\checkmark$ & $\begin{array}{c}\text { rq } \\
\text { QS/18 } \\
9\end{array}$ & $\begin{array}{c}\text { University of } \\
\text { Paris Sud (Paris } \\
11)\end{array}$ & فرنسا \\
\hline$\checkmark$ & $\checkmark$ & $\checkmark$ & $\checkmark$ & $\checkmark$ & $\checkmark$ & $\begin{array}{c}\varepsilon \cdot \\
\mathrm{QS} / 49\end{array}$ & $\begin{array}{c}\text { University of } \\
\text { British Columbia }\end{array}$ & كندا \\
\hline- & $\checkmark$ & $\checkmark$ & $\checkmark$ & - & $\checkmark$ & $\begin{array}{c}\text { \&1 } \\
\text { QS/33 }\end{array}$ & $\begin{array}{c}\text { The University of } \\
\text { Manchester }\end{array}$ & المملكة المتحدة \\
\hline- & - & - & $\checkmark$ & - & - & $\begin{array}{c}\varepsilon r \\
Q S / 45\end{array}$ & $\begin{array}{l}\text { University of } \\
\text { Copenhagen }\end{array}$ & الدانمارك \\
\hline- & $\checkmark$ & $\checkmark$ & $\checkmark$ & - & $\checkmark$ & $\begin{array}{c}\varepsilon r \\
Q S / 54\end{array}$ & $\begin{array}{c}\text { University of } \\
\text { North Carolina at } \\
\text { Chapel Hill }\end{array}$ & الو لأيات المتحدة \\
\hline- & - & - & $\underline{\checkmark}$ & - & - & $\varepsilon \varepsilon$ & $\begin{array}{c}\text { karolinska } \\
\text { institutet }\end{array}$ & السويد \\
\hline$\checkmark$ & $\checkmark$ & $\checkmark$ & $\checkmark$ & - & $\checkmark$ & $\begin{array}{c}\text { ¿0 } \\
\mathrm{QS} / 14 \\
9\end{array}$ & $\begin{array}{c}\text { University of } \\
\text { California, Irvine }\end{array}$ & الو لأيات المتحدة \\
\hline$\checkmark$ & $\checkmark$ & $\checkmark$ & $\checkmark$ & - & $\checkmark$ & $\varepsilon 7$ & $\begin{array}{c}\text { The University of } \\
\text { Texas } \\
\text { Southwestern } \\
\text { Medical Center at } \\
\text { Dallas }\end{array}$ & الو لأيات المتحدة \\
\hline$\checkmark$ & $\checkmark$ & $\checkmark$ & $\checkmark$ & - & $\mathrm{P}$ & $\begin{array}{c}\varepsilon V \\
Q S / 85\end{array}$ & $\begin{array}{c}\text { University of } \\
\text { California, Davis }\end{array}$ & الو لايات المتحدية \\
\hline$\checkmark$ & $\checkmark$ & $\checkmark$ & $\checkmark$ & $\checkmark$ & $\checkmark$ & $\begin{array}{c}\leqslant \wedge \\
\mathrm{QS} / 12 \\
5\end{array}$ & $\frac{\underline{\text { University of }}}{\underline{\text { Southern }}} \underline{\text { California }}$ & الو لأبات المتحدة \\
\hline$\checkmark$ & - & $\checkmark$ & $\checkmark$ & - & $\checkmark$ & $\begin{array}{c}\text { ¿q } \\
\mathrm{QS} / 18 \\
1\end{array}$ & $\begin{array}{l}\text { Vanderbilt } \\
\text { University }\end{array}$ & الو الايات المتحدية \\
\hline
\end{tabular}




\begin{tabular}{|c|c|c|c|c|c|c|c|c|}
\hline$\checkmark$ & $\checkmark$ & - & $\underline{\checkmark}$ & - & $\checkmark$ & $\begin{array}{c}\circ . \\
Q S / 53\end{array}$ & $\begin{array}{c}\text { Technical } \\
\text { University } \\
\text { Munich } \\
\end{array}$ & ألمانيا \\
\hline$\checkmark$ & $\checkmark$ & $\checkmark$ & $\underline{\checkmark}$ & $\checkmark$ & $\checkmark$ & $\begin{array}{c}r \cdots \\
101 \\
Q S / 25 \\
3 \\
\end{array}$ & جامعة الملك سعود & السعودية \\
\hline - & $\checkmark$ & $\checkmark$ & $\checkmark$ & - & $\checkmark$ & $r+. \cdot$ & جامعة الملك عبد & السعودية \\
\hline- & - & - & $\underline{\checkmark}$ & $\checkmark$ & $\checkmark$ & $\begin{array}{c}\varepsilon \cdots \\
r \cdot 1 \\
Q S / 21 \\
6 \\
\end{array}$ & للبترول والمعادن المان & السعودية \\
\hline- & - & - & $\checkmark$ & $\checkmark$ & $\checkmark$ & $\begin{array}{c}\varepsilon \cdots \\
r \cdot 1 \\
Q S / 21 \\
6 \\
\end{array}$ & جامعة الملكت عبد الله & السعودية \\
\hline- & - & - & $\checkmark$ & - & - & $\begin{array}{c}0 \ldots- \\
\varepsilon \cdot 1 \\
Q S / 55 \\
1-600\end{array}$ & جامعة القاهرة & مصر \\
\hline r & rᄉ & rr & 00 & $1 \leqslant$ & rq & \multicolumn{3}{|c|}{ الإجمالي } \\
\hline$\%^{r \wedge}$ & $\% 79$ & $\% 01$ & $\% 1$. & $\%$ ro & $\%^{v}$. & \multicolumn{3}{|c|}{ النسبة } \\
\hline
\end{tabular}

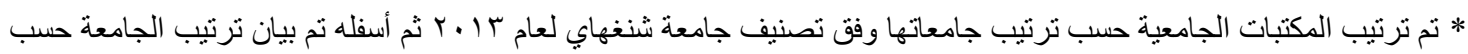
تصنيف مؤسسة QS في نفس العام، وكما اشير ا تفصيلاً في المقدة المنهجية لا يوجد بون شاسع في ترتيب الجامعات وفق هذين التصنيفين. * تجدر الإشارة إلى أن علامة (P) المستخدمة في هذا العمود نثير إلى وجود موقع إلكتروني للمكتبة الجامعية قد تم تهيئتها

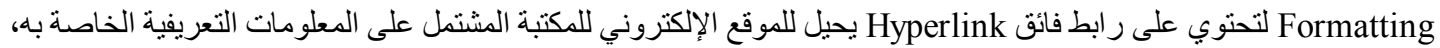

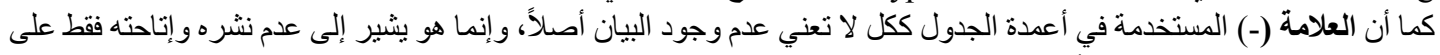

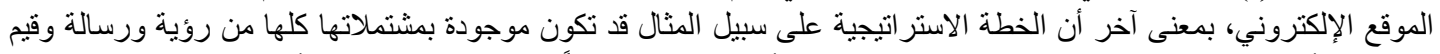

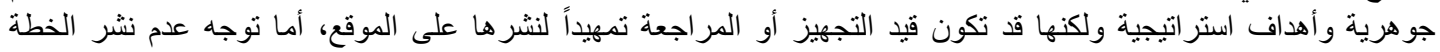

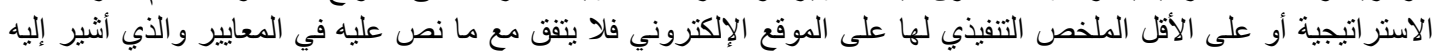
تفصيلاً في الجزء الخئة ألى الاص بالدر اسة النظرية. 